\title{
Stream-Aquifer Interactions in the Straight River Area, Becker and Hubbard Counties, Minnesota
}

By J.R. Stark ${ }^{1}$, D.S. Armstrong ${ }^{1}$, and D.R. Zwilling ${ }^{2}$

U.S. Geological Survey

Water-Resources Investigations Report 94-4009

Prepared in cooperation with the Minnesota Department of Natural Resources and the Legislative Commission on Minnesota Resources

Mounds View, Minnesota 1994

1 U.S. Geological Survey

2 Minnesota Department of Natural Resources 


\section{U.S. DEPARTMENT OF THE INTERIOR \\ Bruce Babbitt, Secretary \\ U.S. GEOLOGICAL SURVEY \\ Gordon P. Eaton, Director}

For additional information write to:

District Chief U.S. Geological Survey 2280 Woodale Drive Mounds View, MN 55112
Copies of this report can be purchased from:

U.S. Geological Survey

Earth Science Information Center

Open-File Reports Section

Box 25286, MS 517

Denver Federal Center

Denver, CO 80225 


\section{Contents}

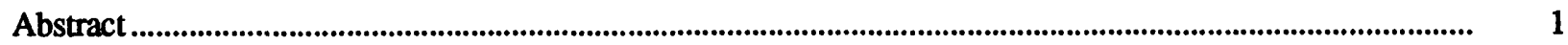

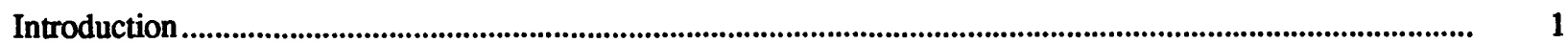

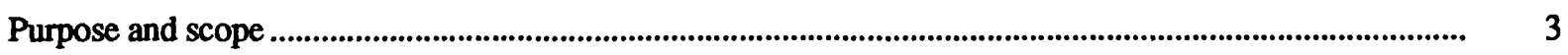

Location and physical setting of investigation area ................................................................................ 3

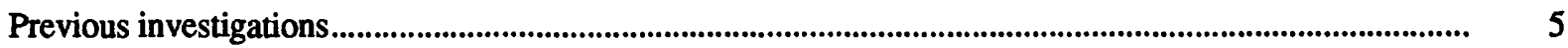

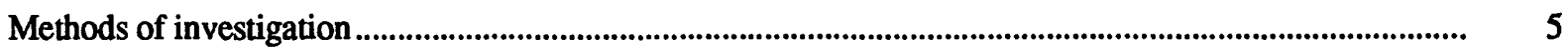

Test-hole and well-numbering system ........................................................................................................... 9

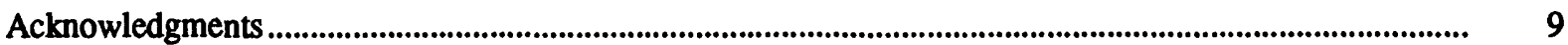

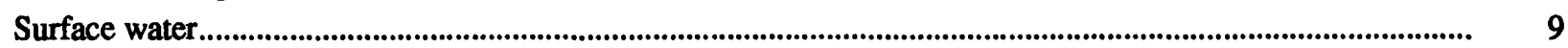

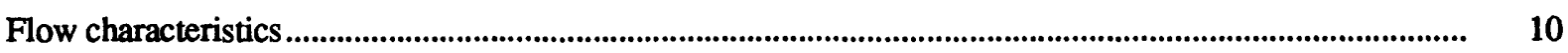

Daily fluctuation in stream discharge ............................................................................................ 11

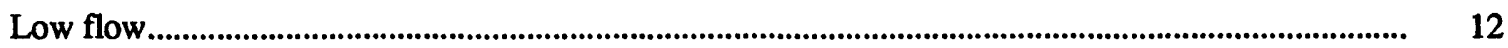

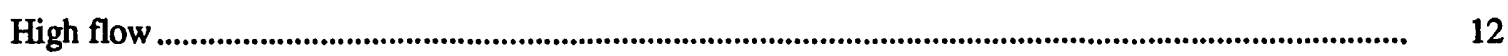

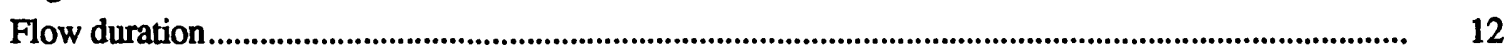

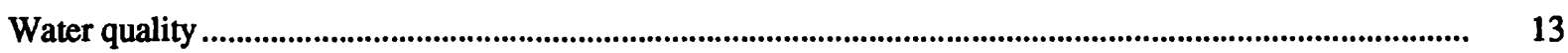

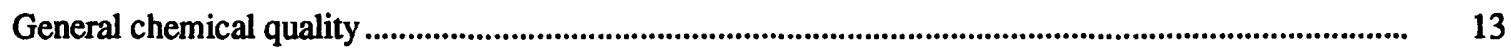

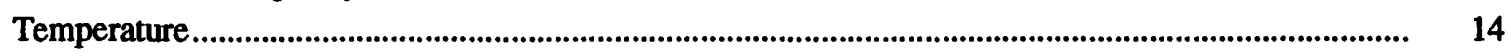

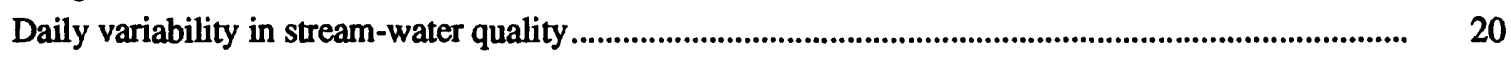

Water quality and quantity for trout habitat ............................................................................................ 20

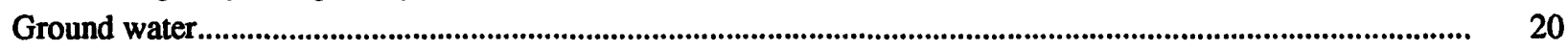

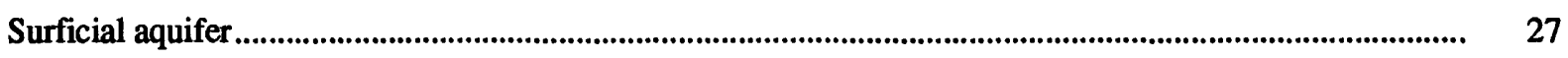

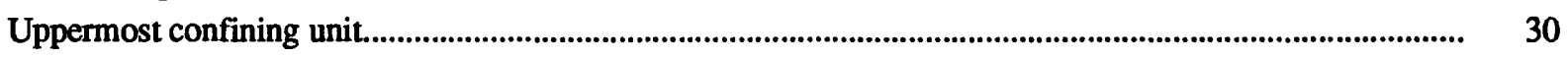

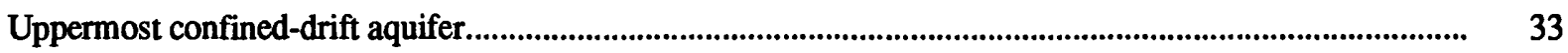

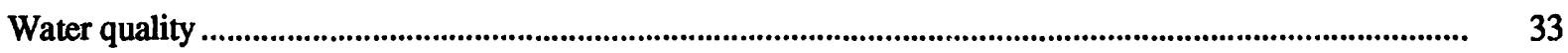

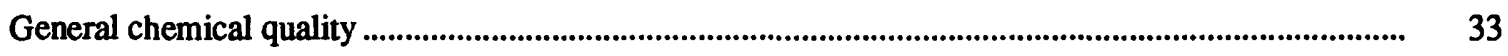

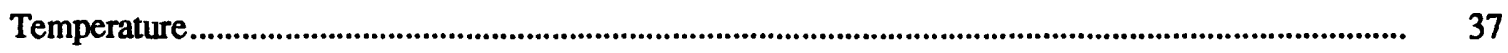

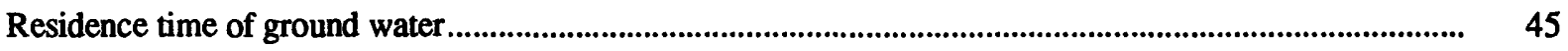

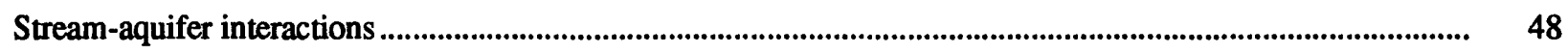

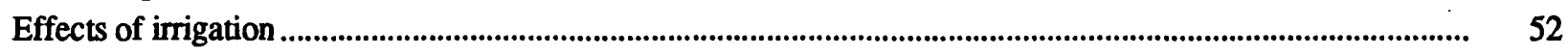

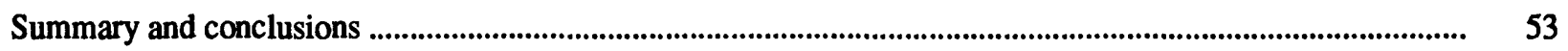

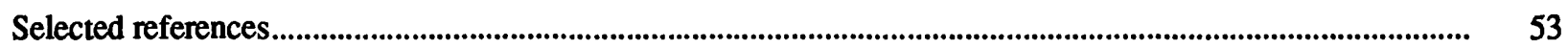

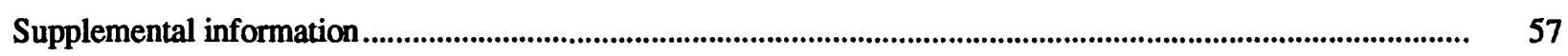

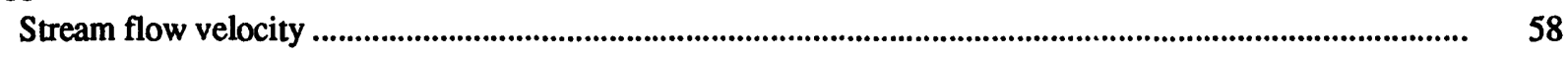

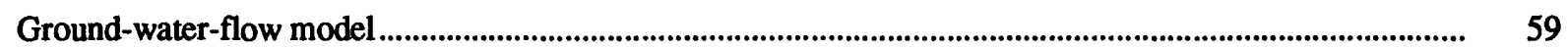

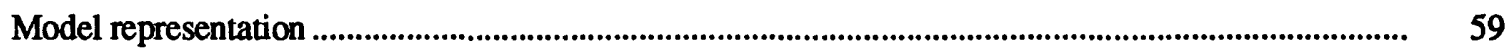

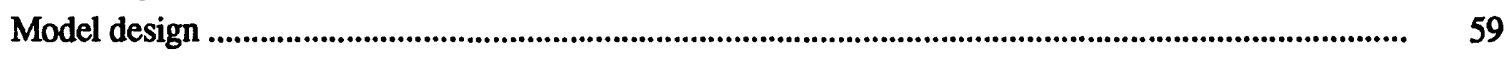

Sensitivity analysis and model evaluation ................................................................................................. 63

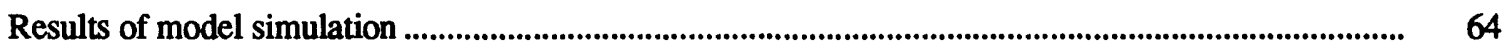

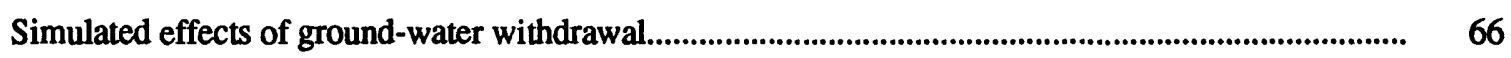

Stream-temperature model ........................................................................................................................................ 66 


\section{List of Illustrations}

Figure 1-2. Map showing:

1. Location of Straight River Basin, investigation area, and surficial geology in Becker and Hubbard Counties, Minnesota

2. Generalized hydrologic system of the Straight River investigation area.

3. Graph showing annual precipitation during 1894 through 1988 at Park Rapids, Minnesota

4-6. Map showing:

4. Location of irrigation wells and municipal-well field in the investigation area

5. Hydrologic data-collection sites in the Straight River investigation area

6. Test hole and well-numbering system

7-8. Graph showing:

7. Flow-duration curves for continuous-record stations on the Straight River during the 1988 water year

8. Cumulative discharge of Straight River at continuous-record stations during the 1988 water year.

9-14. Graph showing:

9. Temperature of air, stream and ground water, and hydraulic head of ground water and of the Straight River at Becker County Road 125, May 1988 through August 1989

10. Variability of air, stream, and ground-water temperature at Osage, Minnesota and at U.S. Highway 71 near Park Rapids, Minnesota during January 1989

11. Variability of air, stream, and ground-water temperature at Osage, Minnesota and at Becker County Road 125 near Osage, Minnesota during July 1988

12. Variability of stream temperature in Straight River during July 1988

13. Variability of $\mathrm{pH}$, air and stream temperature, and dissolved oxygen of Straight River at Osage, Minnesota and at U.S. Highway 71 near Park Rapids, Minnesota July 12-13, 1988

14. Variability of stream temperature and dissolved oxygen of Straight River, July 12-13, 1988

15-16. Map showing:

15. Altitude of potentiometric surface (water table) of surficial aquifer during August 1988

16. Altitude of the top of the uppermost confining unit

17. Graph showing hydraulic head in Minnesota Department of Natural Resources well 3006 screened in the surficial aquifer, Becker County, during calendar years 1974 through 1989 


\section{Illustrations--Continued}

18-22. Map showing:

18. Change in hydraulic head in wells screened in the surficial aquifer, 1985-88

19. Change in hydraulic head in wells screened in the surficial aquifer, April 1987 through September 1987

20. Altitude of the top of uppermost confined-drift aquifer

21. Thickness of the uppermost confined-drift aquifer

22. Altitude of potentiometric surface of the uppermost confined-drift aquifer during August 1988

23. Graph showing water level in Minnesota unique well number 139200 screened in the uppermost confined-drift aquifer, 1985-89

24. Map showing change in hydraulic head in wells screened in the uppermost confineddrift aquifer, November 1985 through September 1988

25. Piper diagram showing percentage of total milliequivalents per liter of major ions in samples collected from surficial and uppermost confined-drift aquifers and from Straight River during 1988

26. Map showing nitrate concentrations in ground water

27-28. Graph showing:

27. Temperatures and water levels in surficial and uppermost confined-drift aquifers at irrigated and nonirrigated areas in the investigation area

28. Model-calculated, ground-water inflow and outflow for simulations representing pre-development, 1988, and hypothetical rates of ground-water withdrawal from the investigation area

29-31. Map showing:

29. Areal extent, finite-difference grid, and boundary conditions for layer 1 of ground-water-flow model.

30. Areal extent, finite-difference grid, and boundary conditions for layer 2 of ground-water-flow model

31. Areal extent, finite-difference grid, and boundary conditions for layer 3 of ground-water-flow model

32-34. Graph showing:

32. Measured and model-simulated stream temperature of Straight River at Becker County Road 125 during May through September 1988.

33. Change in model-simulated temperature of Straight River at U.S. Highway 71 during May through September 1988, resulting from reduced base flow due to irrigation withdrawal of ground water, Straight River, Minnesota. 


\section{Illustrations--Continued}

32-34. Graph showing (continued):

34. Changes in model-simulated temperature of Straight River at Becker County Highway 125 during May through September 1988, resulting from a simulated 5-degree Celsius decrease in the temperature of discharge from Straight Lake.

\section{List of Tables}

Table

1. Monthly mean stream discharge of Straight River at continuous-record stations, Becker and Hubbard Counties, Minnesota during 1988 water year.

2. Chemical and physical characteristics of water from Straight River.

3. Chemical and physical characteristics of ground water in the investigation area

4. State-recommended limits for domestic consumption and agricultural and wildlife use for selected constituents in ground water, and percentage of wells sampled in the investigation area where water exceeds limits

5. Stream base-flow data computed at permanent-record stations in Straight River, Becker and Hubbard Counties, Minnesota

6. Summary of data from time-of-travel study of the Straight River, August 1988

7. Withdrawal rates for model cells representing high-capacity production wells in the investigation area used during simulations of four-month 1988 summer period.

8. Sensitivity of hydraulic heads in the surficial and uppermost confined-drift aquifers to changes in values of model variables, Straight River Basin, Minnesota.

9. Selected model-input parameters after calibration and used for hypothetical groundwater withdrawal and drought scenarios

10. Model-computed water budget for the Straight River Basin

11. Data for wells completed in surficial aquifer, Straight River area, Becker and Hubbard Counties, Minnesota

12. Data for wells completed in uppermost confined-drift aquifer, Straight River area, Becker and Hubbard Counties, Minnesota. 


\section{Conversion Factors, Vertical Datum, and Abbreviated Water-Quality Units}

Readers who prefer to use metric (International System) units rather than inch-pound units can make conversions using the following factors:

$\begin{array}{lcl}\text { Multiply Inch-Pound Unit } & \text { By } & \text { Toobtain Metric Unit } \\ \text { inch (in.) } & 25.4 & \text { millimeter } \\ \text { foot (ft) } & .3048 & \text { meter } \\ \text { mile (mi) } & 1.609 & \text { kilometer } \\ \text { foot per day (ft/d) } & .3048 & \text { meter per day } \\ \text { foot per mile }(\mathrm{ft} / \mathrm{mi}) & .1894 & \text { meters per kilometer } \\ \text { cubic foot }\left(\mathrm{ft}^{3}\right) & .02832 & \text { cubic meters } \\ \text { cubic foot per second }\left(\mathrm{ft}^{3} / \mathrm{s}\right) & 28.32 & \text { liter per second } \\ \text { foot squared per day }\left(\mathrm{ft}^{2} / \mathrm{d}\right) & .09294 & \text { meter squared } \\ \text { gallon (gal) } & .003785 & \text { cubic meter } \\ \text { gallon per minute }\left(\mathrm{gal} / \mathrm{min}^{2}\right) & .06308 & \text { liter per second } \\ \text { acre } & .4047 & \text { hectare } \\ \text { acre-foot (acre-ft) } & 1,233 & \text { cubic meter } \\ \left.\text { square mile (mi }{ }^{2}\right) & 2.590 & \text { square kilometer } \\ \text { degree Fahrenheit }\left({ }^{\circ} \mathrm{F}\right) & \left({ }^{\circ} \mathrm{F}-32\right) / 1.8 & \text { degree Celsius }\left({ }^{\circ} \mathrm{C}\right)\end{array}$

Chemical concentrations are given in metric units. Chemical concentrations of substances in water are given in milligrams per liter $(\mathrm{mg} / \mathrm{L})$ or micrograms per liter $(\mu \mathrm{g} / \mathrm{L})$. Milligrams per liter is a unit expressing the concentration of chemical constituents in solution as weight (milligrams) of solute per unit volume (liter) of water. One thousand micrograms per liter is equivalent to one milligram per liter

Sea level In this report "sea level" refers to the National Geodetic Vertical Datum of 1929 (NGVD of 1929)-- a geodetic datum derived from a general adjustment of the first-order level notes of both the United States and Canada, formerly called "Sea Level Datum of 1929". 


\section{Glossary}

The geologic and hydrologic terms pertinent to this report are defined as follows:

Aquifer: Formation, group of formations, or part of a formation that contains sufficient saturated permeable material to yield significant quantities of water to wells or springs.

Base flow: Sustained streamflow, mainly consisting of ground-water discharge to a stream.

Confined aquifer: An aquifer bounded above and below by confining units. An aquifer containing confined ground water. Synonymous with a buried aquifer where hydraulic head rises above the top of the aquifer in a tightly cased well.

Confining unit: Body of material with low vertical permeability stratigraphically adjacent to one or more aquifers. Replaces the terms aquiclude, aquitard and aquifuge.

Drawdown: Vertical distance between the static (nonpumping) hydraulic head and hydraulic head caused by groundwater withdrawal.

Drift: General term applied to all material (clay, sand, gravel, and boulders) transported and deposited by glacial ice or melt water.

Evapotranspiration: Water discharged to the atmosphere by evaporation from water surfaces, moist soil, and by plant transpiration.

Ground water: The part of subsurface water that is in the saturated zone.

Head, hydraulic: The height above a standard datum of the surface of a column of water that can be supported by the static pressure at a given point.

Hydraulic conductivity: Capacity of porous material to transmit water under pressure. It is the rate of flow of water passing through a unit section of area under a unit hydraulic gradient.

Hydraulic gradient: The change in hydraulic head per unit distance of flow in a given direction. Synonymous with potentiometric gradient.

Isotope: Any of two or more species of atoms of a chemical element with the same number and position in the periodic table and nearly identical chemical behavior but with differing atomic mass or mass number and differing physical properties.

Outwash: Washed, sorted, and stratified drift deposited by water from melting glacial ice.

Permeability: Measure of the relative ease with which a porous medium can transmit a fluid under a potential gradient.

Potentiometric surface: A surface that represents the static head of water in an aquifer; it is defined by the levels to which water will rise in tightly cased wells from a given point in an aquifer.

Saturated zone: The zone in which all voids are ideally filled with water. The water table is the upper limit of this zone. Water in the saturated zone is under pressure equal to or greater than atmospheric.

Specific capacity: The rate of discharge of water from a well divided by the drawdown of water level within the well. 
Specific yield: The ratio of the volume of water that an aquifer material will yield by gravity drainage to the volume of the aquifer material.

Storage coefficient: The volume of water an aquifer releases from or takes into storage per unit surface area of the aquifer per unit change in head. In an unconfined aquifer, it is virtually equal to the specific yield.

Till: Unsorted, unstratified clay, silt, sand, gravel, or boulders of glacial origin.

Transmissivity: The rate at which water of the prevailing kinematic viscosity is transmitted through a unit width of an aquifer under a unit hydraulic gradient.

Unconfined aquifer: Saturated zone between the water table and the first underlying confining unit; an aquifer that has a water table. Surficial aquifers are unconfined aquifers.

Water table: The surface in an unconfined ground-water body at which the water pressure is atmospheric. Generally, this is the upper potentiometric surface of the zone of saturation.

Water year: The period from October 1 through September 30. Water year is designated by the calendar year in which it ends and which includes 9 of the 12 months. Thus, the year ending September 30, 1993 is called the 1993 water year. 


\section{Abstract}

The Straight River, in north-central Minnesota, is a trout stream having cold, clear water. The 75-square-mile Straight River watershed contributes flow to the stream. The watershed is underlain by highly transmissive surficial and confined-drift aquifers. Ground-water discharge from these aquifers sustains flow in the Straight River, and the cold water supports a population of trout. Water withdrawals from these aquifers are increasing in response to changes in land use from dry-land to irrigated farming. Degradation of the stream's habitat for trout could result from the following: a decrease in ground-water discharge to the stream caused by ground-water withdrawals for irrigation, an increase in ground-water temperature resulting from percolation of irrigated water to the ground-water system, and introduction of agricultural chemicals to the stream through ground-water flow or runoff.

Physical data indicate a hydraulic connection between the stream and the surficial aquifer. Discharge of the Straight River increases from about 25 cubic feet per second at the outfall from a reservoir near the headwaters to about 51 cubic feet per second near the mouth. The rate of streamflow gain during summer decreases downstream, possibly as a result of ground-water withdrawal for irrigation. The water table and potentiometric surface of the uppermost confined-drift aquifer generally slope to the southeast and locally toward rivers and lakes; gradients decline to about 5 feet per mile from spring to summer.

Daily fluctuations of stream temperature are as great as 15 degrees Celsius during the summer, primarily in response to changes in air temperature. Ground-water discharge to the Straight River decreases stream temperature during the summer. Results of simulations from a stream-temperature model indicate that daily changes in stream temperature are strongly influenced by solar radiation, wind speed, stream depth, and ground-water inflow. Results of simulations from ground-water-flow and stream-temperature models developed for the investigation indicate a significant decrease in ground-water flow could result from ground-water withdrawal at rates similar to those measured during 1988 . This reduction in discharge to the stream could result in an increase in stream temperature of 0.5 to 1.5 degrees Celsius. Nitrate concentrations in shallow wells screened at the water table, in some areas, are locally greater than the limit set by the Minnesota Pollution Control Agency. Nitrate concentrations in water from deeper wells and in the stream are low, generally less than 1.0 milligram per liter.

\section{Introduction}

The Straight River, in Becker and Hubbard Counties, Minnesota (fig. 1), is a trout stream having cold, clear water. According to State officials (Dennis Ernst, Minnesota Department of Natural Resources, written commun., 1990), the stream is one of the most productive trout-fishing streams in Minnesota. The stream is an important recreational resource partly because it is located in the north-central part of the State where trout streams are uncommon. Streams designated as trout streams in Minnesota are regulated by the Minnesota Department of Natural Resources (MDNR) to help protect the quantity and quality of the water. The Straight River is similar to many streams in the upper midwest that flow through and receive ground-water discharge from glacial outwash. Ground and surface water are closely related in the Straight River watershed. Infiltration through the permeable soils is rapid when the soils are free of frost, resulting in substantial recharge to highlytransmissive surficial aquifers that are hydraulically connected to the stream. The surface drainage to the Straight River, about 75 square miles in area, is underlain by highly transmissive confined and surficial sand and gravel (drift) aquifers. Flow of the Straight River is sustained by discharge from these aquifers, especially during periods of no rainfall.

Brook trout (Salvelinus fontinalis Mitchill) were common in the Straight River as late as the 1940's, but now are absent (Dennis Ernst, oral commun., 1990). In addition to adequate stream discharge, brook trout require cold, clear water with a silt-free, rocky substrate (Raleigh, 1982). The temperature of streams is critical because brook trout do not thrive in water where the temperature exceeds $20^{\circ} \mathrm{C}$ (degrees Celsius) for extended periods. The Straight River presently is too warm a habitat for brook trout.

Brown trout (Salmo trutta) were introduced into the Straight River in the 1940's and are abundant in the stream today (Dennis Ernst, oral commun., 1990). The stream produces some of the largest brown trout in Minnesota. Brown trout require stream conditions similar to brook trout. Like brook trout, the most importantenvironmental factor that determines suitable habitat for brown trout is water temperature. Brown trout, however, can survive in warmer water than brook trout (Raleigh and others, 1986). The maximum, near-lethal water temperature for brown trout is $27^{\circ} \mathrm{C}$, and optimum temperatures for growth and survival range from 12 to $19^{\circ} \mathrm{C}$. During the summer of 1988 , temperature and streamflow in the 

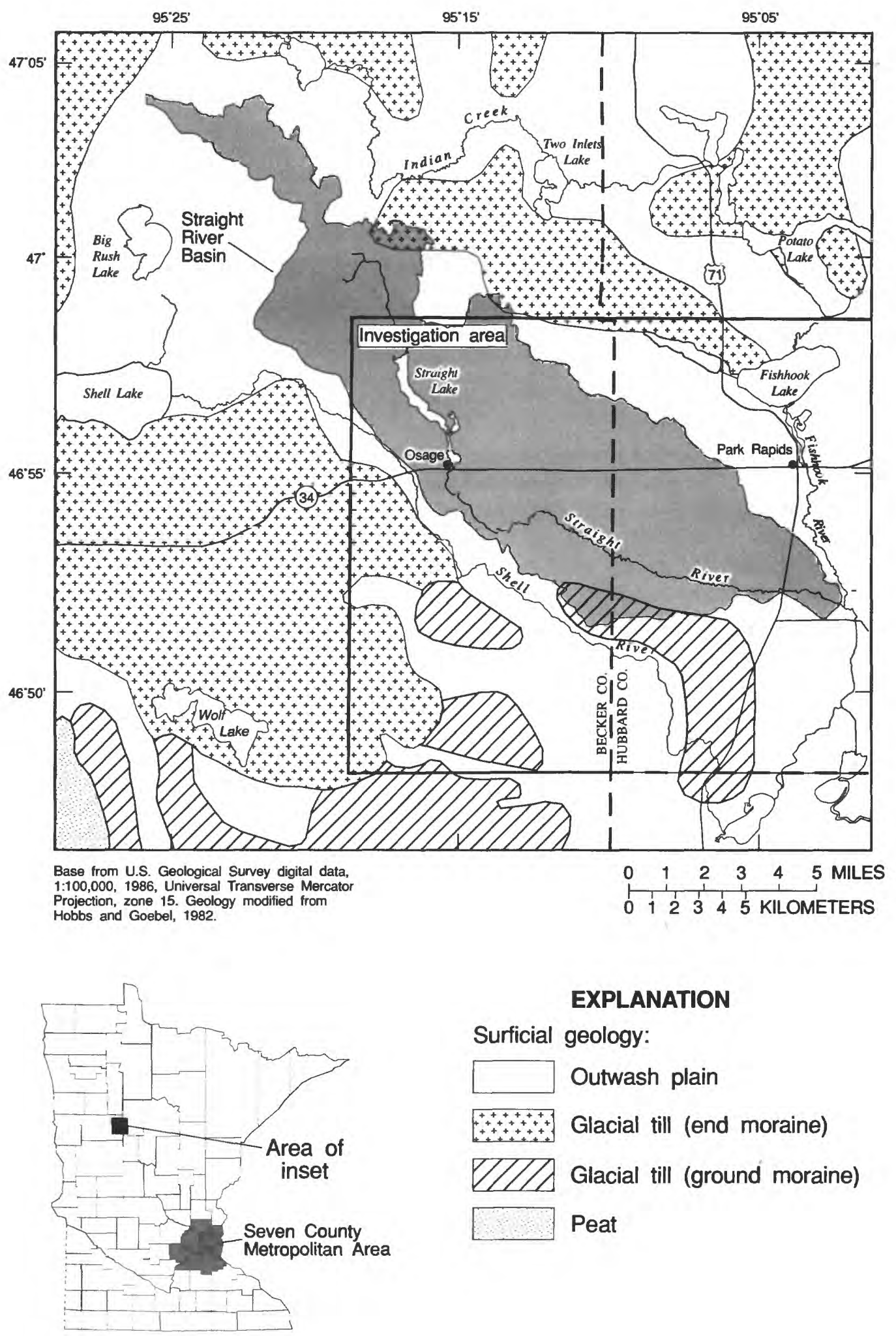

\section{EXPLANATION}

Surficial geology:

$\square$ Outwash plain
$\square$ Glacial till (end moraine)
$\square$ Geacial till (ground moraine)
$\square$

Figure 1.--Location of Straight River Basin, investigation area, and surficial geology in Becker and Hubbard Counties, Minnesota. 
Straight River approached conditions that are lethal for brown trout.

Land use in the Straight River watershed is changing from dry-land to irrigated farming. Sandy soil and the availability of ground water have made the area a good location for large-scale cultivation of potatoes. In 1974, there were five irrigation wells in the area. By 1988 (a relatively dry year) there were 48 irrigation wells screened in drift aquifers. About 2.3 billion gallons of ground water were withdrawn from these wells for irrigation from May through August 1988. During the same period, total discharge near the mouth of the Straight River was about 4.0 billion gallons. Most irrigation is within $2 \mathrm{mi}$ (miles) of the Straight River.

Withdrawal of water through irrigation wells could cause prolonged or permanent changes in the direction or magnitude of ground water flowing toward the stream. Such a reduction of streamflow resulting from groundwater withdrawal is called stream depletion (Jenkins, 1968).

The temperature of stream water would increase as the amount of cold ground-water flow discharging to the stream is reduced. Decreased stream discharge also results in a smaller thermal mass and thus the stream would be more susceptible to warming from solar radiation. Increased stream temperature also could result from a warming of ground water discharging to the stream because of warm irrigation return flow to the aquifer. Anecdotal information indicates that water temperature of Straight River has increased during the last several years. Data on stream temperature, however, were not well documented prior to this investigation, and few stream-discharge or water-quality measurements of the stream had been made.

Agricultural chemicals applied to the land may percolate to the shallow ground-water system. These chemicals could then migrate with ground-water flow as dissolved constituents and discharge to the stream. These water-quality factors could affect the ability of the stream to maintain a stable trout population.

Local officials are concemed that ground-water withdrawals for irrigation and intensive agriculture may adversely affect the quantity, quality, and temperature of ground water and water in the stream, and that these changes could degrade the stream's habitat for trout. This investigation was considered a priority by the MDNR and by the Legislative Commission on Minnesota Resources (LCMR) to examine the potential effect of irrigation on the quantity, quality, and temperature of ground and surface water in the area and was conducted by the U.S. Geological Survey (USGS) in cooperation with these agencies.

\section{Purpose and Scope}

This report describes hydrologic conditions in the Straight River watershed, including ground- and surfacewater quantity and quality. The report also presents an estimate of the effects of ground-water withdrawal for irrigation on ground water and on surface water. Specifically, this report describes: (1) the variability in streamflow and ground-water levels, (2) stream and ground-water quality, (3) stream-aquifer interaction, and (4) the effect of irrigation on the quantity and quality of ground water and of the Straight River.

This report contains four parts. The first part of the report describes the quantity and quality of water in the Straight River. The second part describes the aquifers that discharge to the stream, defines quantity and quality of water in the aquifers, and describes seasonal changes in ground-water levels, flow, and quality. The third part describes interaction between the stream and the aquifers and the fourth part discusses the effects of irrigation.

\section{Location and Physical Setting of Investigation Area}

The investigation area is about 180 mi northwest of the Twin City Metropolitan Area, Minnesota, and covers approximately $240 \mathrm{mi}^{2}$ (square miles), including parts of Becker and Hubbard Counties (fig. 1). The investigation area does not include the entire Straight River Basin; parts of the investigation area are outside of the Straight River Basin. The investigation area is underlain by an extensive surficial aquifer consisting of glacial outwash. This aquifer is part of a large surficial aquifer system, called the Pinelands Sands (Helgesen, 1977), which underlies 770 $\mathrm{mi}^{2}$ of Becker, Cass, Hubbard, and Wadena Counties. Confined drift aquifers also underlie most of the investigation area. A generalized section of the hydrologic system in the investigation area is shown in figure 2.

The topography of the Straight River area is generally either flat or gently rolling. The areas to the north and west of the investigation area consist of glacial moraine and have more relief than the outwash plain (shown as outwash in fig. 1). The Straight River flows approximately 19 mi from its source in Becker County to its mouth at the confluence with the Fishhook River in Hubbard County (fig. 1), and is part of the drainage basin of the Crow Wing River, in the Mississippi River drainage system. A dam at Osage stabilizes and raises the level of Straight Lake (fig. 1). This dam, constructed in the 1930 's, also controls and stabilizes streamflow below Straight Lake. The river has no tributaries, and its flow is derived from ground-water discharge, discharge from Straight Lake, and a small amount of overland runoff. 

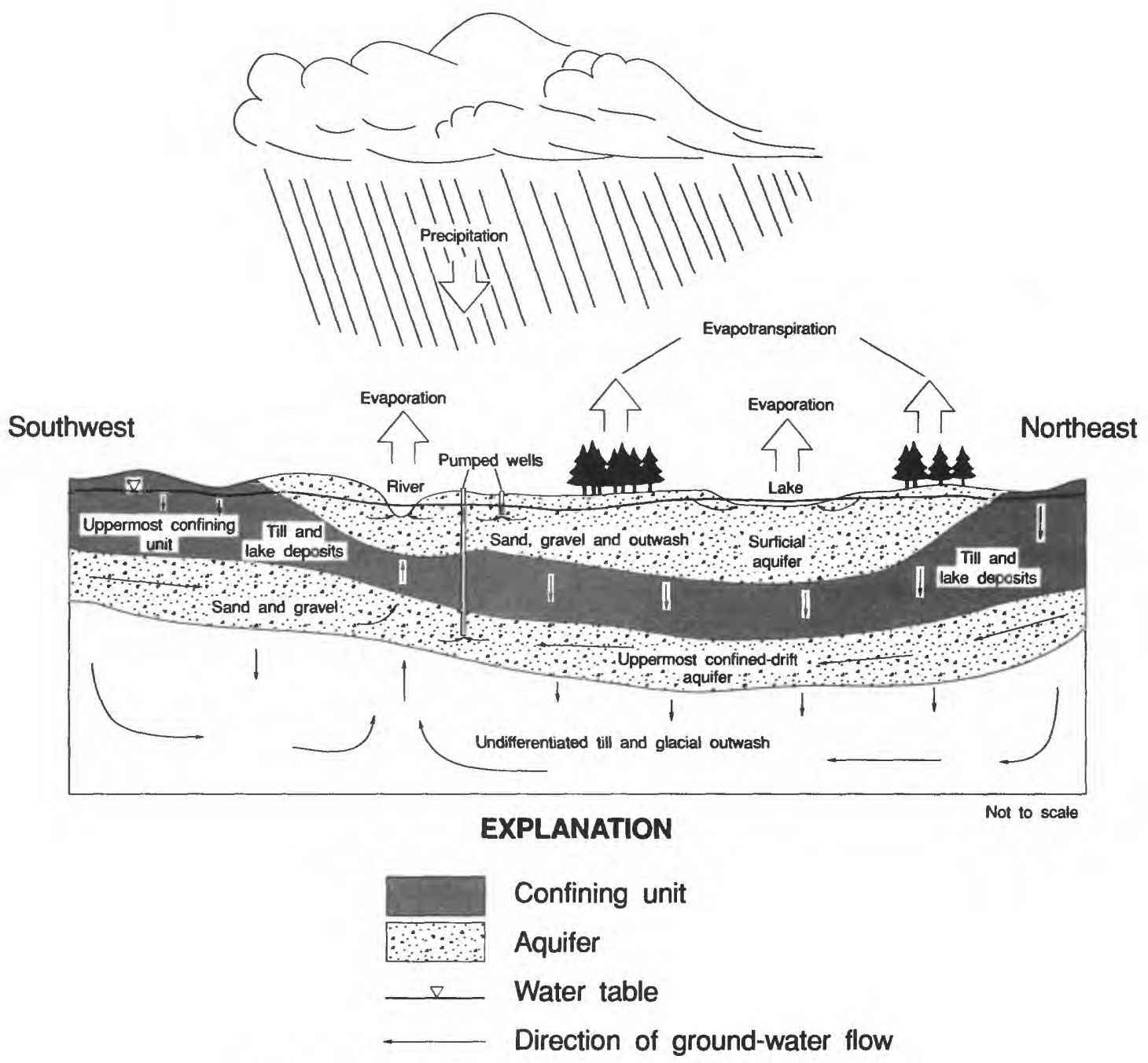

Figure 2.--Generalized hydrologic system of the Straight River investigation area.

Inflow to Straight Lake is primarily from streamflow in the upper Straight River and from ground-water discharge to the lake.

Basement rock, consisting of Proterozoic age (Precambrian igneous and metamorphic rocks includinggranite, gneiss, and schist) (Sims, 1970) and Cretaceous age (sandstone, siltstone, and shale) rocks directly underlie glacial drift throughout the investigation area. The Proterozoic rocks are dense, crystalline rocks with low porosity and permeability. Water is present in fractures and in weathered zones near the upper surface of the rocks. These rocks are not aquifers within the investigation area. The bedrock surface is irregular because of preglacial erosion by rivers and from glacial ice and meltwater during the Pleistocene Epoch.
Although few drill holes have reached the basement rock, a test hole (Minnesota unique-well no. 236103) penetrated Cretaceous shale at $435 \mathrm{ft}$ (feet) below land surface and granitic rock at $544 \mathrm{ft}$ below land surface.

The glacial drift is several hundred feet thick, and thickness increases from south to north (Lindholm and others, 1972). Glacial-drift deposits primarily are till, stratified (glacial) outwash deposits, and glacial-lake deposits. Till, deposited at the base of glaciers during glacial advances, is a poorly sorted mixture of clay, silt, sand, gravel, and boulders. Deposits of till are at the land surface along the edges of the outwash, in isolated locations within the outwash, and buried within the sequence of glacial deposits. Glacial-lake deposits formed as silt and clay were deposited in glacial lakes and 
ponds. These lake deposits were subsequently buried by outwash and till. Stratified sand and gravel (outwash) were deposited in glacial rivers and ponds during periods of glacial stagnation and retreat. Some sand and gravel deposits also were covered by till during subsequent glacial advances. The buried outwash deposits are referred to as confined-drift aquifers. Other sand and gravel units were deposited during the retreat of the last glaciers and are exposed at land surface. These surficial outwash deposits are referred to as surficial (unconfined) aquifers. Till and glacial-lake deposits form confining units within the glacial drift. Both confined and surficial aquifers are present throughout the investigation area, and are the major aquifers used in the area.

Hobbs and Goebel (1982) mapped the surficial geology of the Straight River area using Minnesota soils atlases, LANDSAT satellite imagery, and other published data. Figure 1 shows the distribution of the surficial glacial deposits in the investigation area. This map is based on the work of Hobbs and Goebel with modifications based on more recent test holes drilled for this investigation and well logs from the area.

Glacial deposits that resulted from the Wadena glacial lobe of late Wisconsin age underlie the Straight River watershed. This ice lobe advanced from and retreated to the north-northwest as ice was differentially directed by areas of less competent bedrock (Wright, 1972, and Wright and Ruhe, 1965). The Itasca highland, located north of the Straight River area, is an extensive complex of moraines resulting from this advance.

Discharge from the surficial and confined-drift aquifers mainly is to the Straight River and to irrigation-, domestic-, and municipal-supply wells. Discharge from ground-water by evapotranspiration occurs primarily during the growing season where the water table is within the root zone of vegetation.

Mean annual precipitation ranges from 24 to $26 \mathrm{in}$. (inches) over the investigation area (Baker and Kuehnast, 1978), with most occurring as rain during May to September. Figure 3 shows the range in annual precipitation at Park Rapids during 1894 through 1988. Potential annual evapotranspiration is about 22 in. (Baker and others, 1979).

Land use in the Straight River watershed primarily is agriculture, forestry, and recreation. Agricultural lands are mostly used to grow small-grain crops, corn, and potatoes. Agricultural land use is changing from dry-land to irrigated farming. Light-textured soils and productive aquifers in the area are conducive for large-scale cultivation of potatoes. There were 5 irrigation wells in the watershed in 1974, but by 1988 the number had increased to 48 wells. Ground-water withdrawals from these wells was about 2.3 billion gallons in 1988. Most irrigation withdrawals are within $2 \mathrm{mi}$ of the Straight River (fig. 4). Forested areas consist of second- or thirdgrowth stands of trees that are primarily harvested for paper pulp and wood products.

Residential and urban areas are located outside the Straight River watershed primarily around Park Rapids (1980 population of 2,772). Commercial areas are not extensive, and exist primarily as localized areas of light service industry, food processing, transportation, and commerce.

\section{Previous Investigations}

Early descriptions of the geology of the area were presented by Winchell and Upham (1888) and Winchell and others (1888). A general discussion of geology and ground water is included in the work of Allison (1932). Additional detail on the glacial geology of the area was presented by Leverett (1932), Wright $(1962,1972)$, and Wright and Ruhe (1965). Oakes and Bidwell (1968) described the regional hydrology of the Mississippi Headwaters area. Siegel and Winter (1980) described an investigation of lake/ground-water interactions at Williams Lake in Hubbard County.

Several previous investigations of the ground-water hydrology of the Straight River area have been conducted. Lindholm (1970) appraised the availability of water from glacial outwash immediately southwest of the investigation area. Lindholm and others (1972) made a reconnaissance of the water resources of the Crow Wing River watershed, which included the entire Pinelands Sands area. Helgesen (1977) investigated the groundwater geology of the Straight River watershed as part of a larger investigation of the Pinelands Sands surficial aquifer. This investigation focused on the surficial aquifer and did not include confined-drift aquifers, which are also present in the investigation area. Helgesen published hydraulic conductivity values for the aquifer, a water-table map, a map of theoretical well yields for the area, and maps of the extent, thickness, and hydraulic properties of the aquifer. He also included a map of the water table prior to significant development of groundwater supplies for irrigation. Helgesen developed a twodimensional ground-water-flow model of the Pinelands Sands aquifer. Simulations of hypothetical ground-water withdrawal indicated that development of irrigation supplies from wells in the surficial aquifer would not significantly lower water levels in the aquifer.

\section{Methods of Investigation}

This investigation included the following work elements: (1) design and construction of a data-collection 


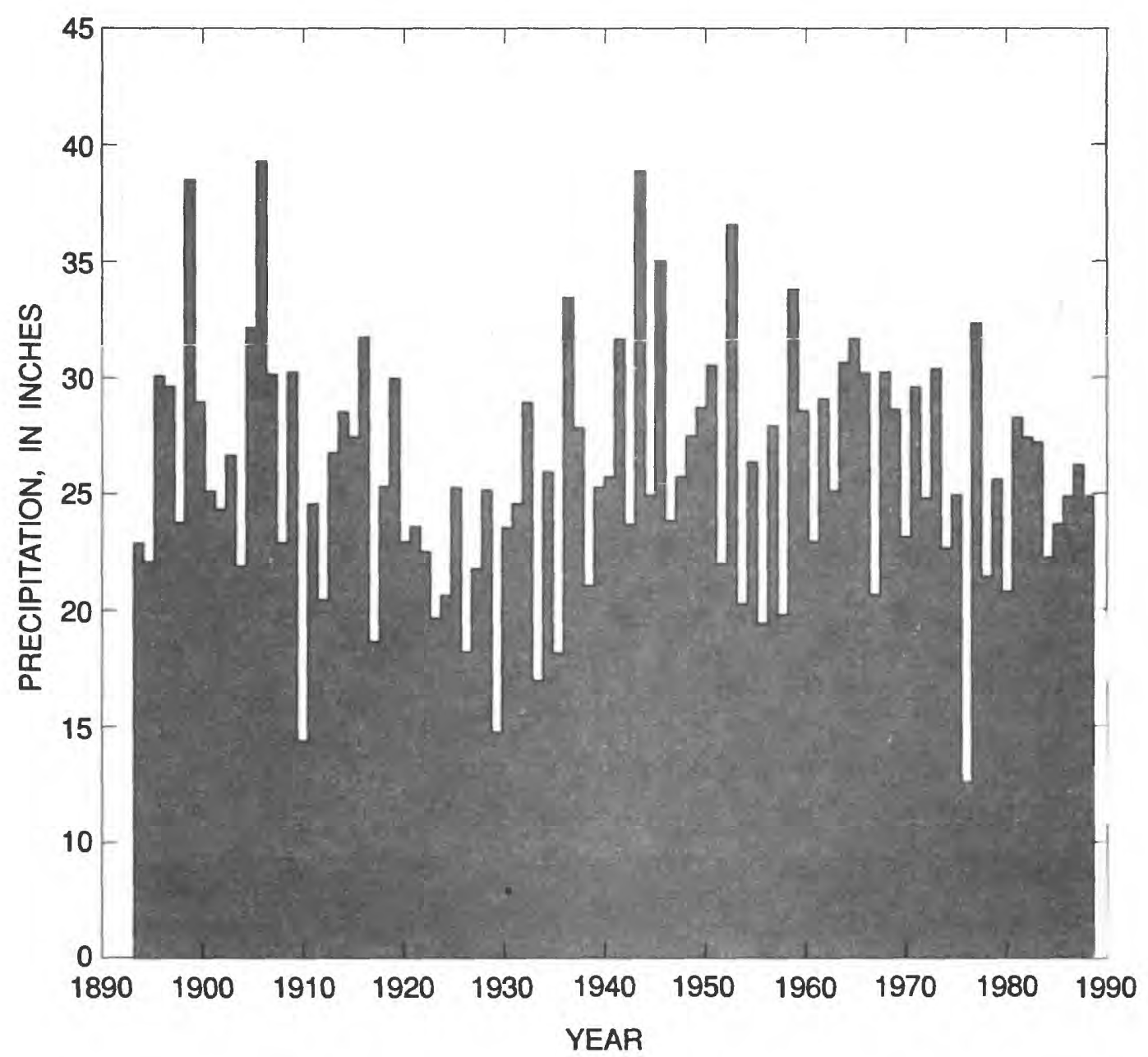

Figure 3.--Annual precipitation during 1894 through 1988 at Park Rapids, Minnesota.

(Data from Minnesota Department of Natural Resources)

network to define hydrology and water quality of the drift aquifers and the stream, (2) measurement of stream and ground-water temperatures to determine seasonal and daily fluctuations and temperature distribution, (3) analyses of hydraulic properties of drift aquifers, potentiometric surfaces, and directions of ground-water flow, (4) construction of ground-water-flow and streamtemperature models to represent the geohydrologic system and the interactionbetween theaquifers and thestream, and (5) application of model simulation results to test the hydrologic system over long periods of time.

Six sites along the Straight River were instrumented to measure stream stage and temperature, and ground-water level and temperature (fig. 5). These sites include three continuous-record stations (sites B, D, and F) and three partial-record stations where stream-stage data were measured periodically (sites A, C, and E). Electronic data loggers, potentiometers, and thermisters were installed at the three continuous-record stations and at one partialrecord station to measure the following: stream stage; ground-water levels in observation wells near the stream; and air, ground-water, and stream-water temperature.

Hydrogeologic maps were constructed using well and test-hole data from the Minnesota Geological Survey (MGS), the MDNR, the USGS, and from geologic logs of test holes drilled for this investigation. The locations of wells having driller's logs were verified by locating wells in the field. Location, geologic and hydrologic information from the logs were entered into a computer data base. Wells and test holes were identified by local well number and by latitude and longitude. The data were used to prepare maps showing the thickness, extent, and 


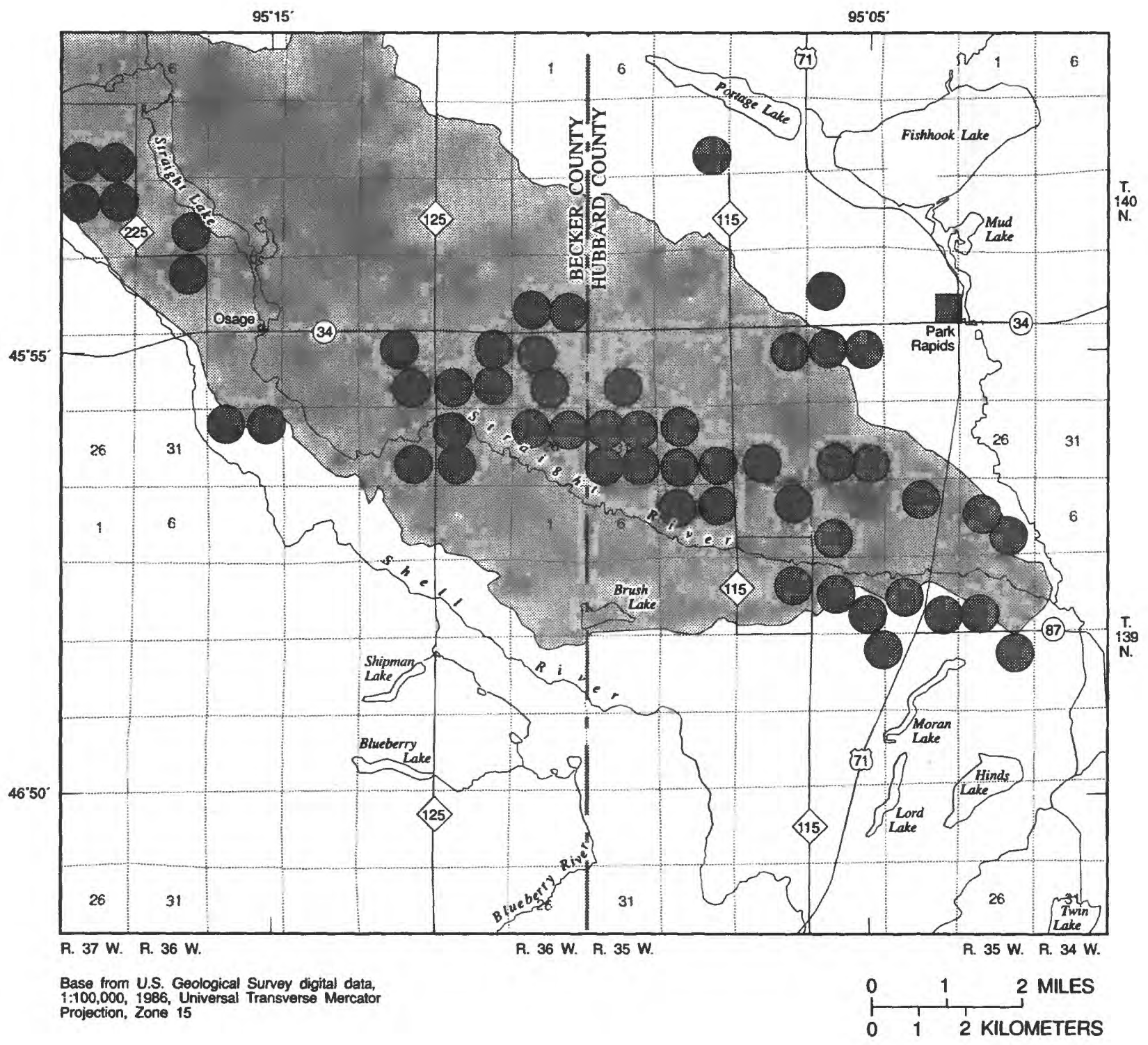

\section{EXPLANATION}

Straight River Basin

Irrigation well--showing area

irrigated, approximately

140 acres.

Figure 4.--Location of irrigation wells and municipal-well field in the investigation area. 


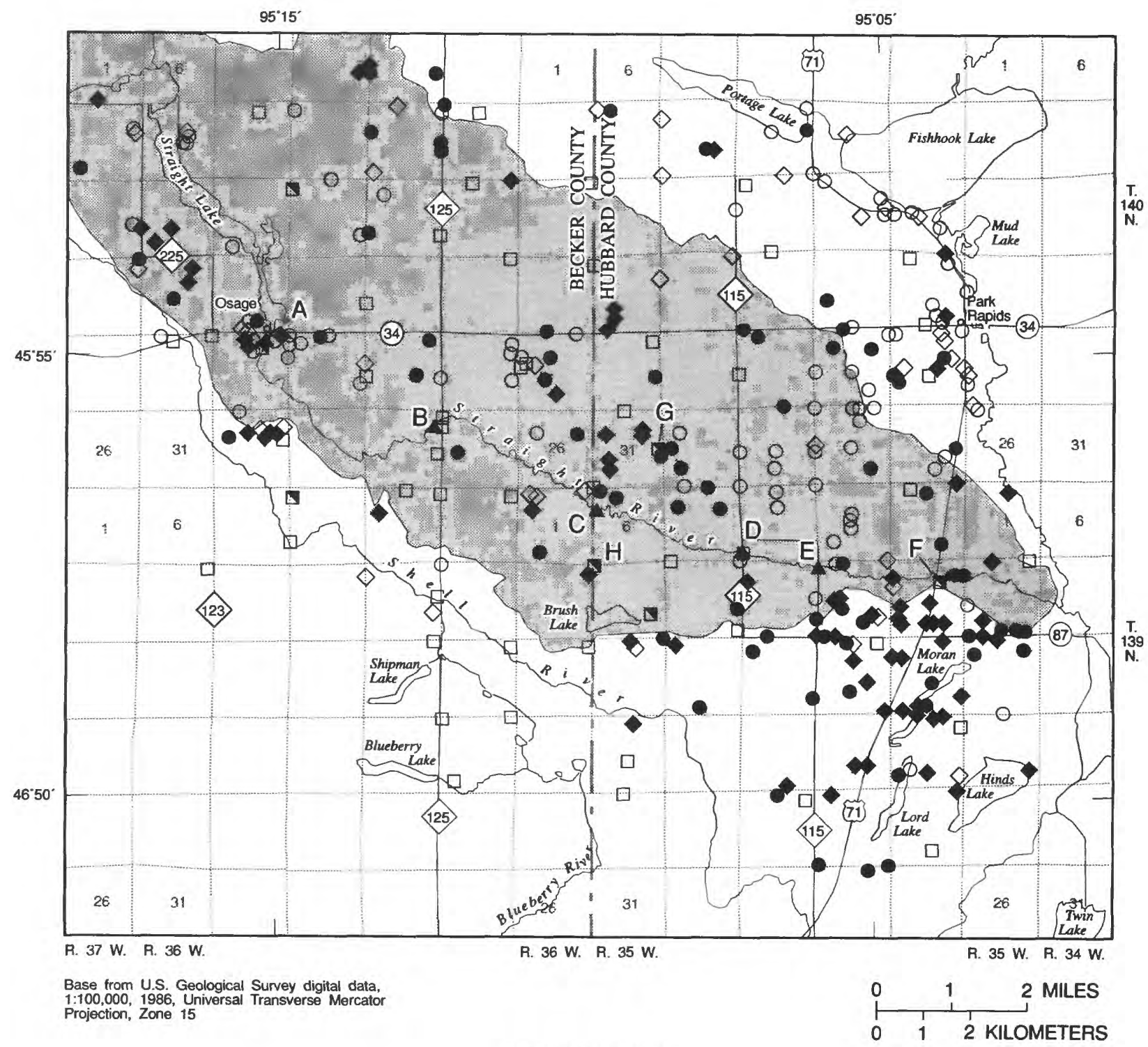

EXPLANATION

\section{Straight River Basin}

Wells completed in surficial aquifer indicated by open symbol

Wells completed in uppermost confined-drift aquifer

indicated by solid symbol

Letter refers to local name of recording site
U.S. Geological Survey well
\ Nested U.S. Geological Survey wells
- $\bigcirc$ Domestic or irrigation well
- $\diamond$ Test well
- Surface-water gage

Figure 5.--Hydrologic data-collection sites in the Straight River investigation area. 
hydrologic properties of the surficial and uppermost confined-drift aquifers and of the uppermost confining unit. Several synoptic measurements of water levels in wells were made during the investigation. These data were used to prepare maps showing position of the water table in the surficial aquifer, and the potentiometric surface of the uppermost confined-drift aquifer.

Ground-water-level and temperature data were measured in nested wells with electronic data loggers, which were installed at different depths (fig. 5). The locations of these nested wells were selected to represent irrigated (site $\mathrm{G}$ ) and nonirrigated (site $\mathrm{H}$ ) parts of the watershed, and to monitor ground-water conditions near the stream (sites A, B, D, and F).

Average values of transmissivity of the surficial aquifer were determined by Helgesen (1977). Average values of transmissivity for the aquifer were estimated by multiplying the estimated-average value of horizontal hydraulic conductivity at a site by the thickness of the aquifer at that location. The method was assumed reasonable because the aquifer materials in the investigation were relatively homogeneous. Vertical hydraulic conductivity of the uppermost confining unit was estimated from a finite-difference ground-water-flow model by simulating vertical hydraulic-head differences across the confining units. Transmissivity of the uppermost confined-drift aquifer was estimated from ground-water-flow model analyses.

Ground-water withdrawal data were obtained from the Minnesota Water-Use-Data System at the MDNR. These data were verified by spot checks during the summer of 1988 at approximately 40 locations using a noninvasive flow meter. Water-use data for 1988 were used to represent ground-water withdrawals for model simulations.

A three-dimensional, finite-difference, ground-waterflow model (McDonald and Harbaugh, 1988) was used to better understand the ground-water flow system, hydrologic budgets, hydraulic properties of hydrogeologic units, and the interactions between the stream and aquifer systems. The model was calibrated to steady-state conditions based on hydrologic data (potentiometric surfaces and streamflow) collected during this investigation. The model also was used to examine the effect of irrigation on regional ground-water levels and stream discharge.

Water from the drift aquifers and from the Straight River was analyzed for major chemical constituents and nutrients to provide baseline water-quality data for use in future assessments and to identify trends caused by landuse practices. Water was collected from 17 wells screened in the surficial aquifer and from 5 wells screened in the uppermost confined-drift aquifer. Grab samples were collected from 4 sites along the Straight River during the summer of 1988 .

A stream-temperature and transport model of the Straight River (Jobson, 1975, 1979, 1980a, 1980b, and Schoellhamer and Jobson, 1986) was used to simulate temperature conditions in the stream and the effect of changes in ground-water discharge to the stream on stream temperature. The model simulated steady-flow conditions of the stream similar to those during the summer of 1988.

\section{Test-Hole and Well-Numbering System}

Two systems of numbering wells and test holes were used for this investigation. The first system used was the MGS Minnesota unique-well number system that associates a well with Universal Transverse Mercator coordinates. The second system of numbering is based on the U.S. Bureau of Land Management's system of land subdivision (township, range, and section). Figure 6 illustrates this numbering system. The first numeral of a test-hole or well number indicates the township, the second the range, and the third the section in which the point is located. Uppercase letters after the section number indicate the location within the section; the first letter denotes the 160-acre tract, the second the 40-acre tract, and the third the 10-acre tract. The letters A, B, C, and $\mathrm{D}$ are assigned in a counterclockwise direction, beginning in the northeast corner of each tract. The number of uppercase letters indicates the accuracy of the location number. For example, the number 140N.36W.22ADC indicates a test hole or well located in the SW1/4, SE1/4, NE1/4, Sec. 22, T.140 N., R.36 W.

\section{Acknowledgments}

The authors are grateful to well owners, well drillers, and State and local agencies for data used in preparing this report. Thanks also go to land owners who permitted test holes to be drilled and observation wells to be installed, and to well owners who permitted their wells to be sampled and measured. Special thanks are extended to Bill Alden, Hubbard County Soil and Water Conservation District, and to Bob Merritt, MDNR, Detroit Lakes, for their coordination of the investigation at the local level, and to Jerry Johnson, MDNR, St. Paul, for his help in preparation of the report figures.

\section{Surface Water}

The Straight River flows approximately $19 \mathrm{mi}$ from its source in Becker County to its mouth in Hubbard County where it discharges to the Fishhook River (fig. 1). The 


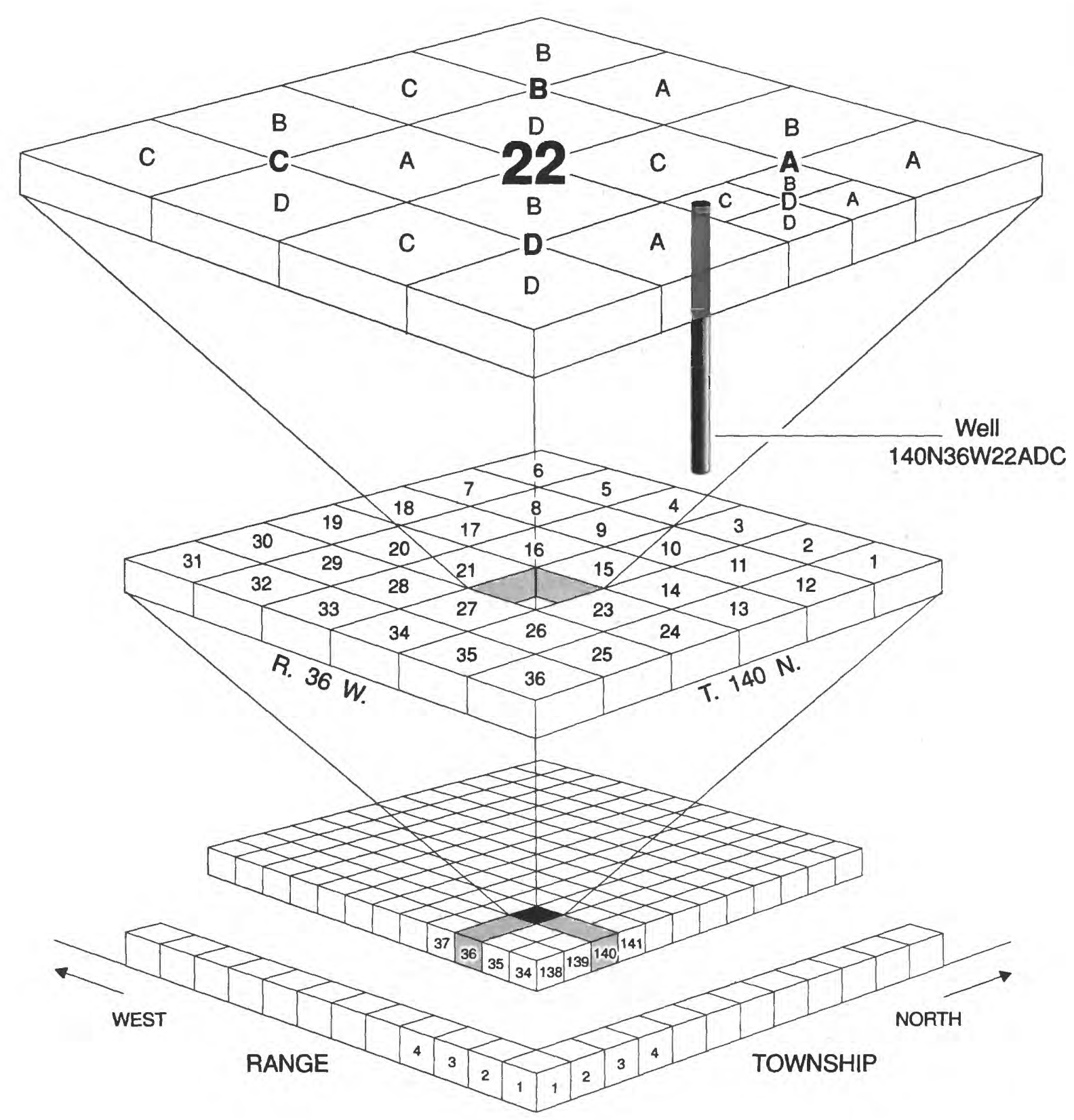

Figure 6.--Test hole and well-numbering system.

area of the watershed is about $75 \mathrm{mi}^{2}$. A dam at the outlet of Straight Lake, near Osage (fig. 1), controls the discharge of the stream. Average daily discharge increases from about $25 \mathrm{ft}^{3} / \mathrm{s}$ (cubic feet per second) at site A, near the outlet of Straight Lake, to about $51 \mathrm{ft}^{3} / \mathrm{s}$ at site F, at U.S. Highway 71 , near the mouth. There are no perennial tributaries to the stream between Osage and the stream's mouth. Most gain in discharge is ground-water seepage from drift aquifers. Discharge is relatively uniform and does not significantly vary by season or in response to short-term dry or wet periods.

\section{Flow Characteristics}

Stream discharge is an indicator of climatic and human-caused variability because discharge is the residual of precipitation after the demands for evapotranspiration and water use are met. Because losses from evapotranspiration are fairly constant from year to 
year in a given area, variations in annual discharge are greater, as a percentage, than variations in annual precipitation (Searcy and Hardison, 1960).

Stage-discharge relations were established at the gaging stations on the stream for October 1987 through September 1988. During this period stream discharge was measured approximately monthly. Records of daily mean discharge were computed for the permanent-record gaging stations at sites B, D, and F (Gunard \& others, 1990). Table 1 is a summary of monthly mean discharge at these stations.

Stream discharge hydrographs reflect three different types of contributions of water from a watershed to a stream. These are from (1) overland flow to the stream, (2) direct channel precipitation, and (3) subsurface flow. Peak discharges result from fast response due to overland flow and direct channel precipitation.

April through August discharge for the 1988 water year may have been below normal based on long-term precipitation data. Although annual precipitation for 1988 (26.32 in.), measured at the Park Rapids weather station, was near the mean of 26 in. (Baker and Kuehnast, 1978), precipitation during April, May, June, and July of 1988 was 4.21 in. less than average.

The total amount of water measured in the Straight River during the 1988 water year at U.S. Highway 71 (site F) was $1,615,000,000 \mathrm{ft}^{3}$ (cubic feet) (Gunard and others, 1990). Measured discharges at sites $B$ and $D$ were $1,157,000,000$ and $1,460,000,000 \mathrm{ft}^{3}$, respectively. Monthly mean discharge ranged from $36.6 \mathrm{ft}^{3} / \mathrm{s}$ at site $B$ to $51.1 \mathrm{ft}^{3} / \mathrm{s}$ at site $\mathrm{F}$. These data indicate that stream discharge increased in a downstream direction during most of the year.

Discharge data from the three permanent-record stations indicate a general increase of $14.5 \mathrm{ft}^{3} / \mathrm{s}$ between sites $B$ and $F$ during the 1988 water year (table 1). The average increase in discharge between sites $B$ and $D$ is 9.6 $\mathrm{ft}^{3} / \mathrm{s}$; between sites $D$ and $F$ it is $4.9 \mathrm{ft}^{3} / \mathrm{s}$ (Gunard and others, 1990).

Monthly mean discharge data (Gunard and others, 1990) also indicate that stream discharge increased downstream throughout the water year. The gain between sites $D$ and $F$ was smaller than the gain between sites $B$ and $D$. Daily-stream discharge data indicate that there were periods during 1988 when daily stream discharge at site $D$ exceeded discharge at site $F$. This indicates that, during these periods the downstream reaches of Straight River were losing water to the aquifer system. The rate of gain in streamflow is less in June to August than in December to February, which may indicate an effect from irrigation withdrawals, evapotranspiration, or both.

\section{Daily fluctuation in stream discharge}

Daily fluctuation in stream discharge were measured during the summer. Similar fluctuations in streams in sand-plain areas in Wisconsin were attributed to evapotranspiration by phreatophytes growing in the stream (Weeks and others, 1965). The maximum discharge during the day in the Straight River generally occurs around noon and the minimum generally occurs around midnight. Daily fluctuation begins during May,

Table 1.--Monthly mean stream discharge of Straight River at continuous-record stations, Becker and Hubbard Counties, Minnesota, during 1988 water year (in cubic feet per second)

\begin{tabular}{|c|c|c|c|c|c|c|c|c|c|c|c|c|c|}
\hline $\begin{array}{c}\text { Station } \\
\text { name } \\
\text { and number }\end{array}$ & Oct. & Nov. & Dec. & Jan. & Feb. & Mar. & Apr. & May & June & July & Aug. & Sept. & $\begin{array}{c}\text { Average } \\
\text { monthly } \\
\text { mean }\end{array}$ \\
\hline $\begin{array}{l}05243721 \\
\text { (site B) } \\
\text { Straight River at Becker } \\
\text { County Road } 125 \text { near } \\
\text { Osage }\end{array}$ & 37.5 & 39.7 & 38.2 & 37.5 & 34.6 & 38.2 & 43.5 & 39.7 & 33.0 & 26.2 & 35.9 & 35.2 & 36.6 \\
\hline $\begin{array}{l}05243723 \\
\text { (site D) } \\
\text { Straight River at Hubbard } \\
\text { County Road } 115 \text { near } \\
\text { Park Rapids }\end{array}$ & 49.5 & 50.2 & 48.7 & 40.1 & 42.2 & 50.0 & 58.8 & 44.3 & 44.8 & 35.8 & 41.6 & 48.3 & 46.2 \\
\hline $\begin{array}{l}05243725 \\
\text { (site F) } \\
\text { Straight River at State } \\
\text { Highway } 71 \text { near Park } \\
\text { Rapids }\end{array}$ & 54.4 & 54.8 & 51.0 & 43.1 & 49.1 & 61.3 & 62.0 & 55.5 & 46.3 & 39.5 & 47.8 & 48.2 & 51.1 \\
\hline
\end{tabular}


gradually increases to a maximum during July and August, and then decreases until it stops during October The fluctuation was most conspicuous when base-flow conditions prevail. At site $F$, the daily change in stage frequently was as great as $0.2 \mathrm{ft}$, corresponding to a change in stream discharge of about $10 \mathrm{ft}^{3} / \mathrm{s}$. Daily fluctuation in discharge may be due to reduced ground-water inflow, evapotranspiration, or a combination of these processes.

\section{Low flow}

Low flow in the Straight River occurred in two distinct periods during water year 1988. The first period was during the winter, when most of the precipitation was stored as snow. The second period was during late summer, when evapotranspiration losses were high and there was little recharge to the ground-water reservoir.

Precipitation during April through July of 1988 was $4.21 \mathrm{in}$. below the average rate of precipitation for that period at Park Rapids, Minnesota. Stream discharge was significantly below normal in other streams in central Minnesota, according to long-term stream discharge records. From these data and the general widespread drought across Minnesota during 1988, it was assumed that flow in the Straight River approached record lows during 1988 . The minimum daily mean discharges recorded at the three permanent-record stations on the Straight River were 23,27 , and $33 \mathrm{ft}^{3} / \mathrm{s}$ (Gunard and others, 1990), which occurred on July 23, 1988 (site B), July 29 and 30, 1988 (site D), and July 23 and 27, 1988 (site F), respectively. Recurrence intervals cannot be assigned to these low-flow stream discharges because of the short period of record available at the sites.

\section{High flow}

Flooding seldom is a problem along the Straight River because of the highly permeable soil. Maximum annual discharge peaks for streams in the area occur during the spring when the infiltration capacity of the soil is low because frost and surface runoff is greater than during summer. The maximum instantaneous flow recorded during the 1988 water year was $71 \mathrm{ft}^{3} / \mathrm{s}$ (site F) on March 24 (Gunard and others, 1990). Recurrence intervals cannot be assigned to high-flow stream discharges because of the short period of record for the stations. Peak stream discharge measured on the Straight River during the 1988 water year did not approach normal peaks because of the drought conditions.

\section{Flow duration}

Flow-duration curves (Searcy, 1959) are cumulativefrequency curves that show the percent of time during which specified stream discharges are equaled or exceeded in a specific period. The curves represent stream-discharge data across a range of stream discharge. Although flow-duration curves do not show the chronological sequence of stream discharge, they are useful in describing the stream discharge characteristics.

The shape of flow-duration curves is determined by hydrologic and geologic characteristics of a watershed. The curves may be used to characterize streamflow of a watershed and to compare the characteristics of different watersheds. A curve with a steep slope indicates a highly variable stream where flow is largely from direct runoff. A curve with a gentle slope indicates a stream that is less responsive to precipitation than a stream where flow is largely from runoff and indicates that the stream dominated by base flow from either ground-water discharge or surface storage. The slope of the lower end of the duration curve indicates the characteristics of the perennial storage (such as lakes or wetlands) in the watershed.

Flow-duration curves were prepared from streamdischarge for data at sites $B, D$, and $F$ (fig. 7). These curves represent data for water year 1988 and are based on daily mean discharge. Flow duration curves computed from one year of stream-discharge records may not be representative of normal conditions, however, they are useful to show the general flow characteristics of the stream. For example, during the 1988 water year the daily mean discharge of the midstream station (site $D$ ) was at least $50 \mathrm{ft}^{3} / \mathrm{s}$ during nearly 50 percent of the year.

The curves from all stations have small slopes, which indicates that the stream was dominated by base flow. The stream did not respond quickly to drought. The stream also did not respond quickly to precipitation. The discharge gain between sites $B$ and $D$ was greater than the increase between sites $D$ and $F$ (fig. 7). The duration curves also indicate that stream discharge was relatively uniform throughout the year. For example, stream discharge at site $F$ varied only from $45-60 \mathrm{ft}^{3} / \mathrm{s}$ for 60 percent of the time during water year 1988 .

Flow-duration data also indicate that discharge at site $B$ was influenced by surface runoff to a greater degree than at stations further downstream. The slope of the flow-duration curve decreases more abruptly for flows that were exceeded 13 percent of the time for this site. 


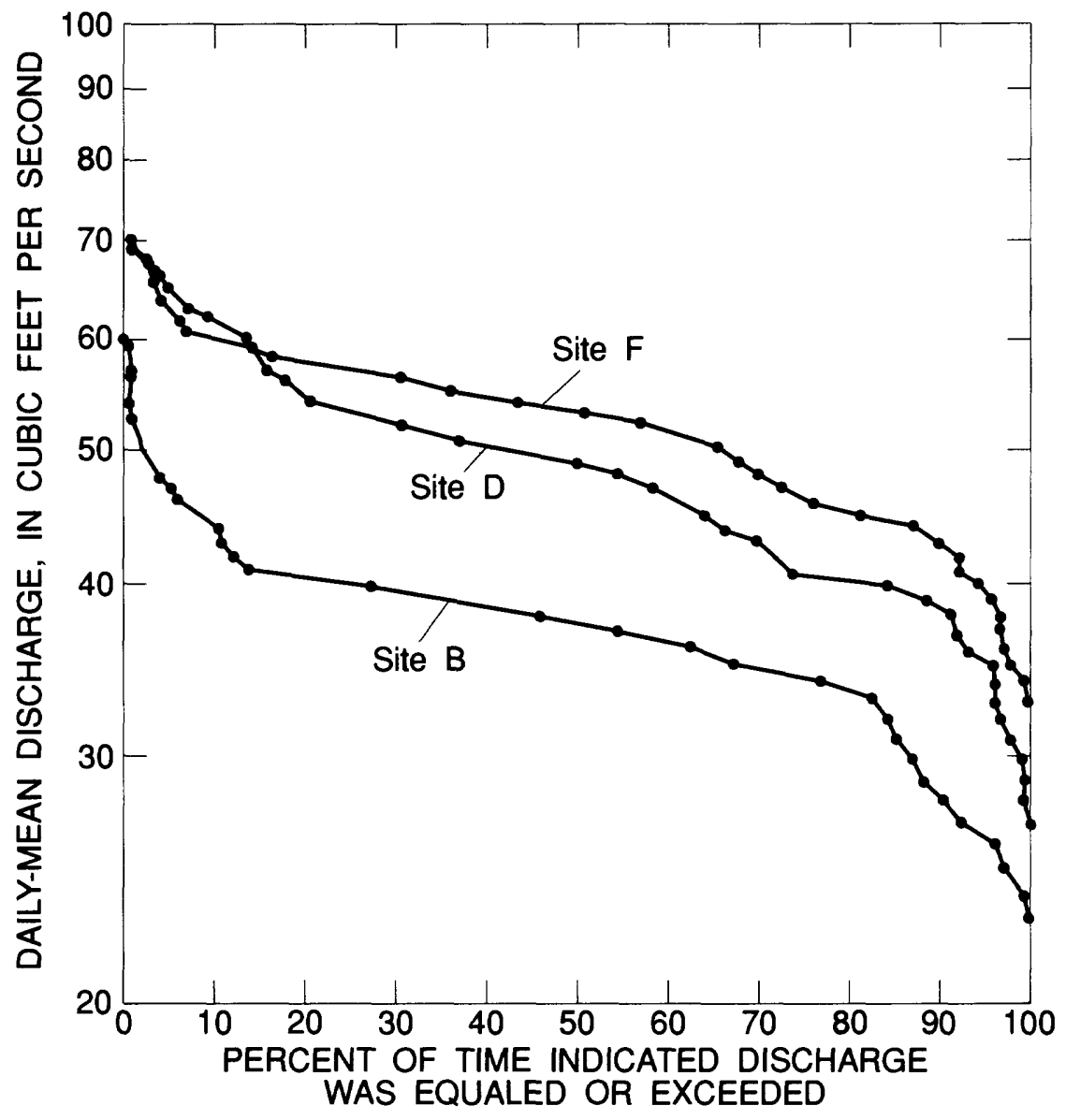

Figure 7.--Flow-duration curves for continuous-record stations on the Straight River during the 1988 water year.

The other stations were not influenced to the same extent by surface runoff, indicating a general lack of surface runoff from the watershed downstream from site $B$.

Cumulative stream discharge curves are another method to examine stream- discharge data (Searcy and Hardison, 1960). These curves, which plot cumulativedaily stream discharge and time, were prepared for the 1988 water year for the three permanent-record stations (fig. 8). The curves allow inspection of changes and trends in discharge for the 1988 water year. A cumulative stream-discharge curve, for discharge evenly divided throughout the year, will plot asa line with a constant slope. For the period May through September 1988, the curves depart from linearity with slopes decreasing with time; this indicates that stream discharge for the stations declined during this part of the 1988 water year.

\section{Water Quality}

\section{General chemical quality}

Chemical constituents in water from the Straight River were determined by analysis of four grab samples collected at four sites on the stream, data collected during a previous investigation that included a sampling site near the headwaters of the Straight River (Ruhl, 1989), and data from a previous investigation by the Minnesota Pollution Control Agency (MPCA) (Willard Mattson, Minnesota Pollution Control Agency, written commun., 1989). The results of these individual chemical analyses are shown in table 2 .

The $\mathrm{pH}$ (a measure of relative acidity) of water in the Straight River is suitable for aquatic life. The Straight River is alkaline, with $\mathrm{pH}$ values generally greater that 8.0 , probably relating to an abundance of carbonate-rich minerals in the glacial deposits within the watershed. A 


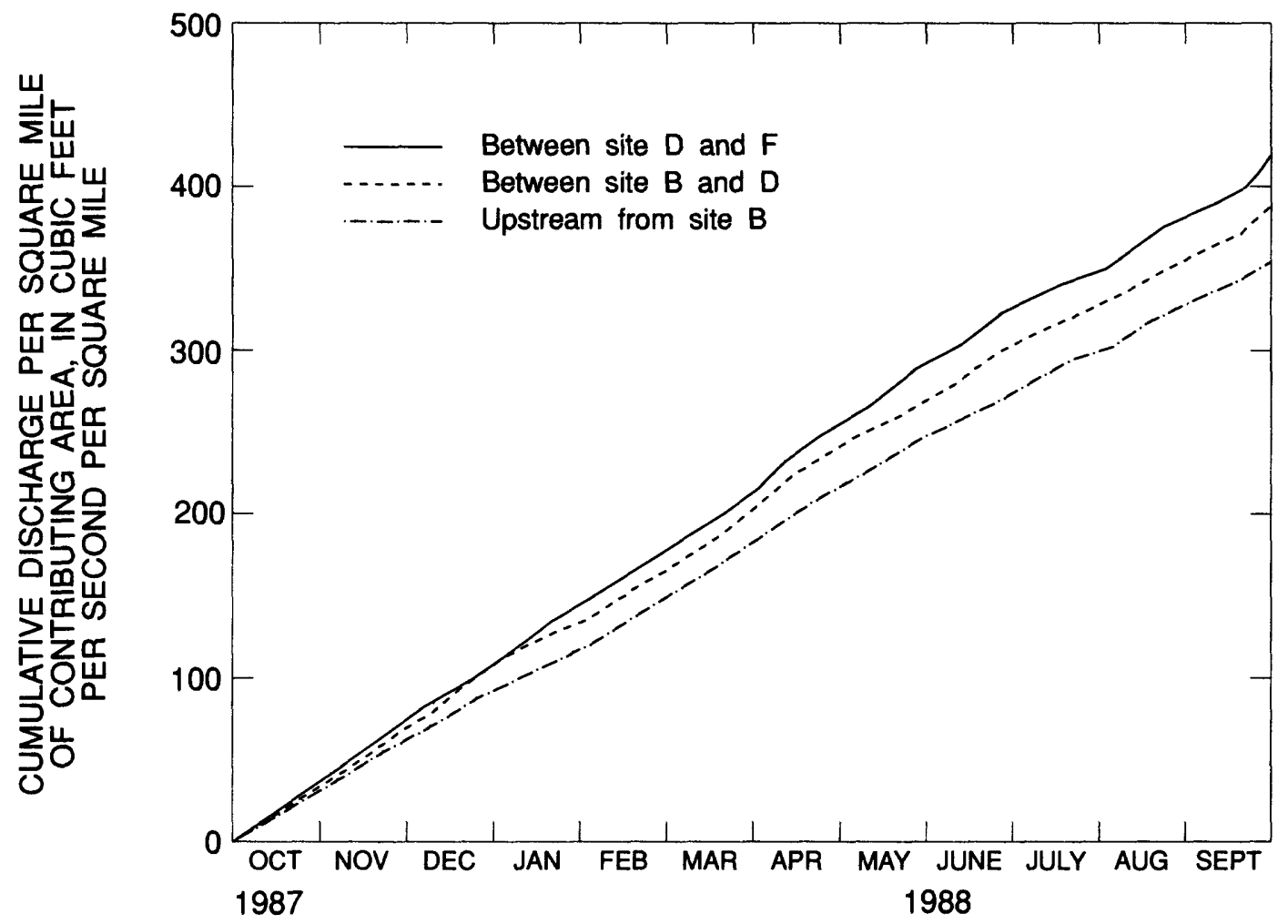

Figure 8.--Cumulative discharge of Straight River at continuous-record stations (sites B, D, and F) during the 1988 water year.

pH range from 6.5 to 9.0 generally is suitable for fish, although the toxicity of some compounds may be effected by the $\mathrm{pH}$ of water (U.S. Environmental Protection Agency, 1986). The $\mathrm{pH}$ of water in the stream tends to be within limits for aquatic life and wildlife, and generally is within the range of 7.7 to 8.6 (tab. 2). With certain $\mathrm{pH}$ conditions, some compounds may become more toxic and some environmentally harmful metals attached to or contained in bottom sediments of lakes and suspended materials in streams may become more soluble in water (U.S. Environmental Protection Agency, 1986).

Predominant chemical constituents in water from the stream are calcium and bicarbonate. The concentrations of major ions in the stream are similar at all sampling sites. The chemical concentrations and physical properties generally meet criteria established by the MPCA (1988) and the Minnesota Department of Health and Minnesota Department of Agriculture (1988) and are suitable for aquatic life, agriculture, wildlife, and domestic consumption. The concentrations of major ions and other properties also are within the recommended limits proposed by the U.S. Environmental Protection Agency (USEPA) for aquatic habitat (U.S.

Environmental Protection Agency, 1986).
Nutrient loading can degrade the water quality of streams if high enough concentrations are present to support abundant growth of algae. Nutrient enrichment of streams can occur because of human activities, such as the use of fertilizer that contains nitrogen and phosphorus compounds, and direct discharge of sewage into streams. In general, the level of nitrate nitrogen (nitrite plus nitrate as $\mathbf{N}$ ) in the Straight River is low.

Triazine-group herbicides were generally not detected in water from the Straight River (tab. 2). Water from one sample (05243720-site A) contained detectable levels of atrazine and cyanazine. This concentration was not confirmed in subsequent samplings.

\section{Temperature}

The temperature in a reach of a stream is affected by net solar radiation to and evapotranspiration from the open water surface, heat added to or lost from the stream by conduction and convection with the air, conduction to the earth, temperature and volume of surface water flowing into and out of the reach, and temperature and volume of ground water flowing into or out of the reach. Net radiation and evapotranspiration depend on the area and 


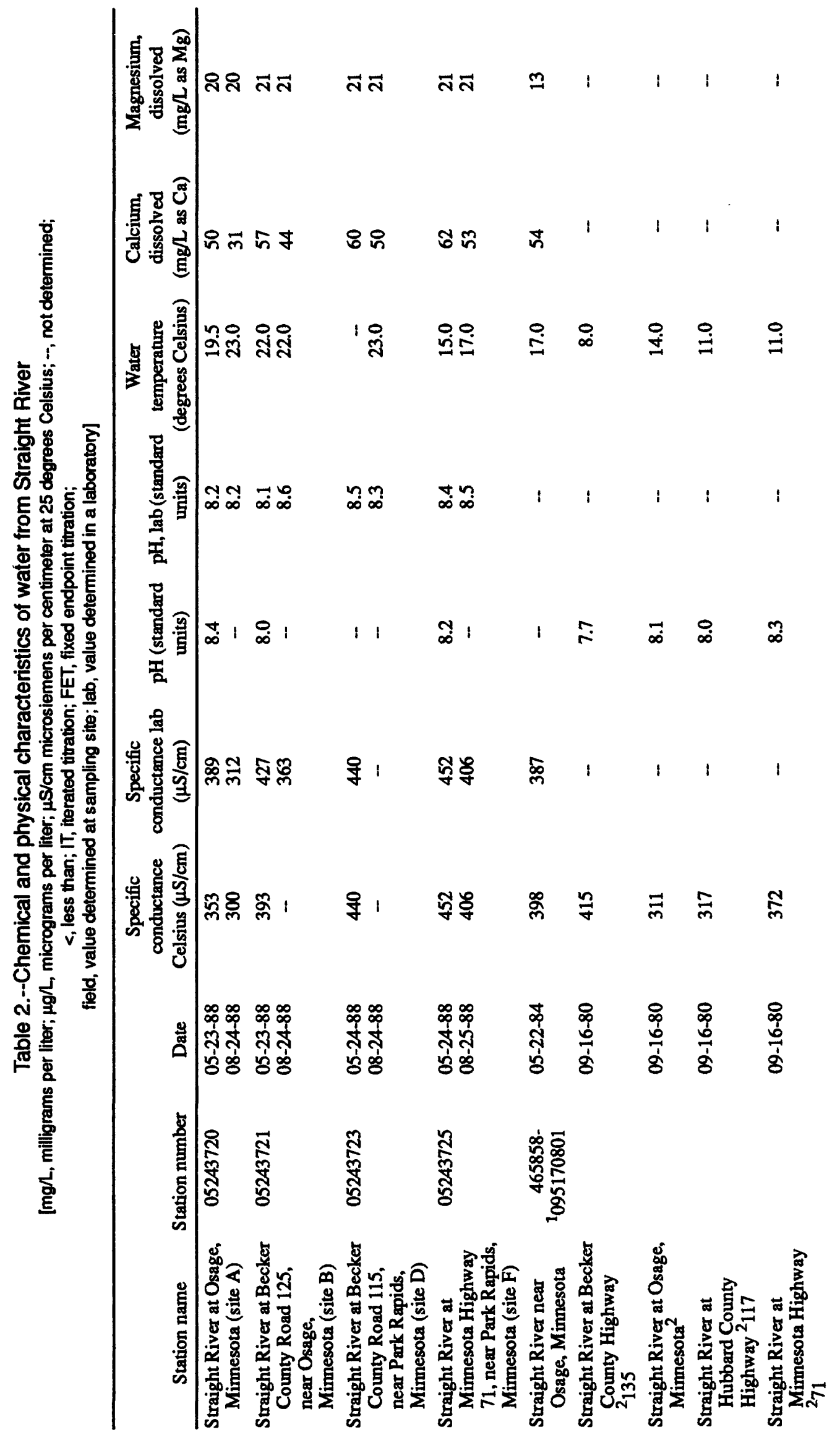




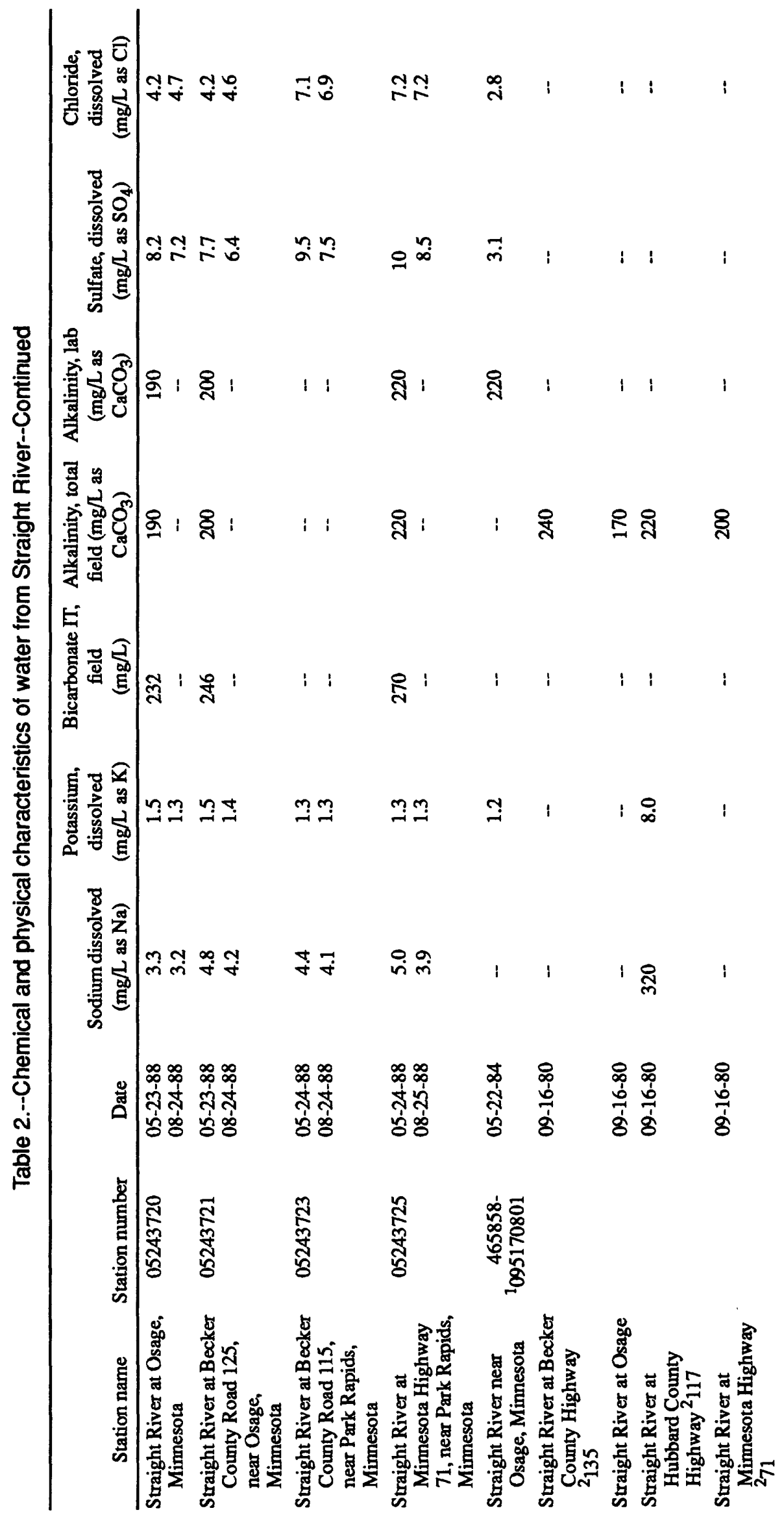




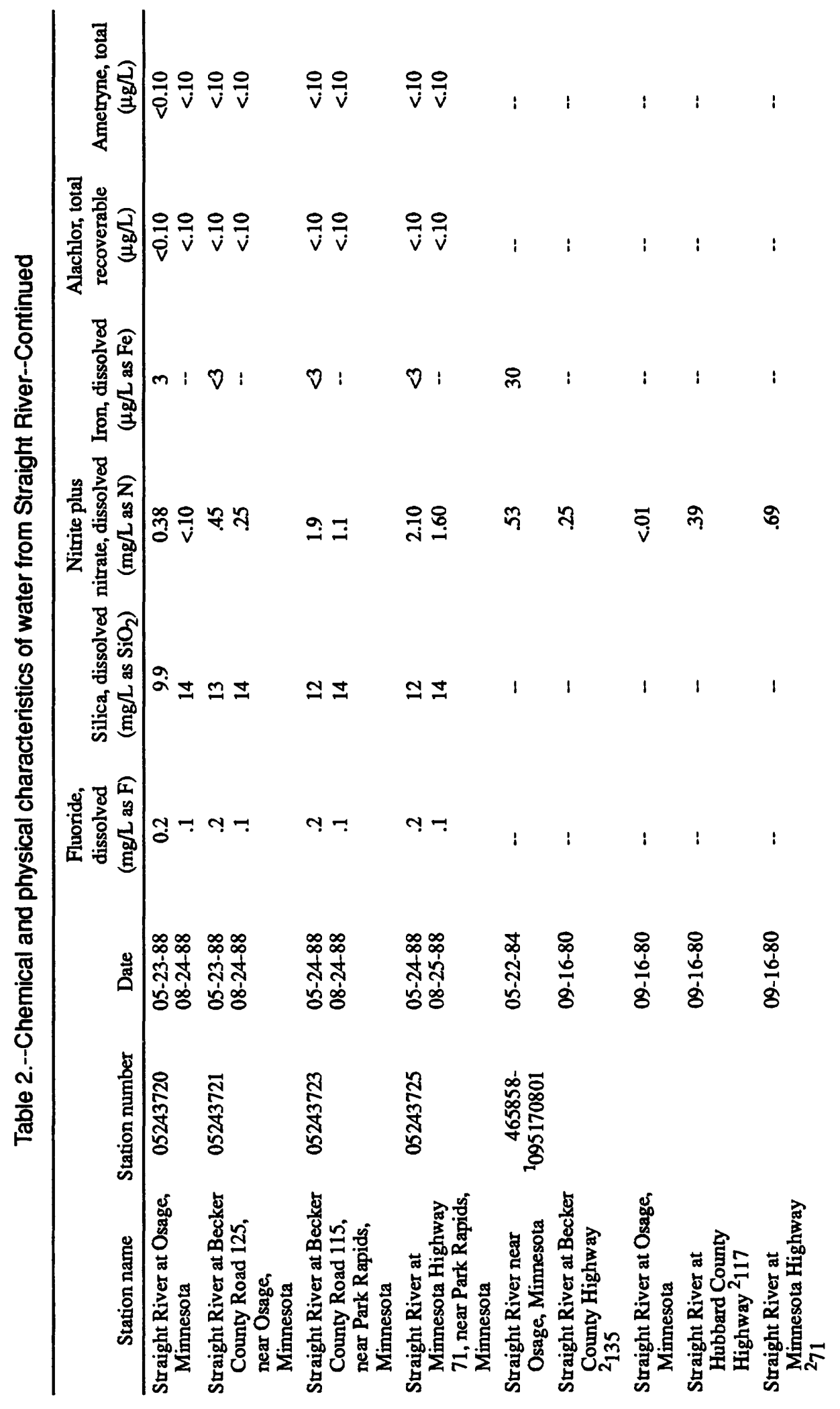




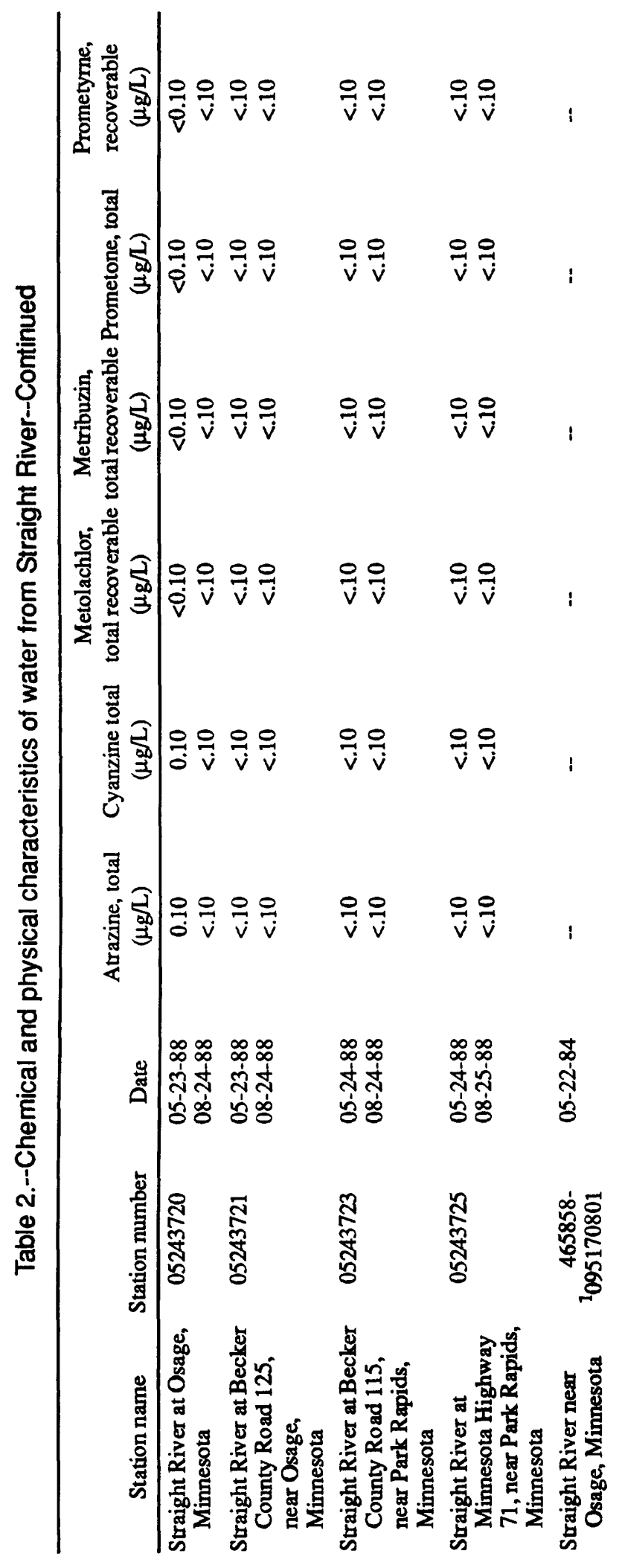




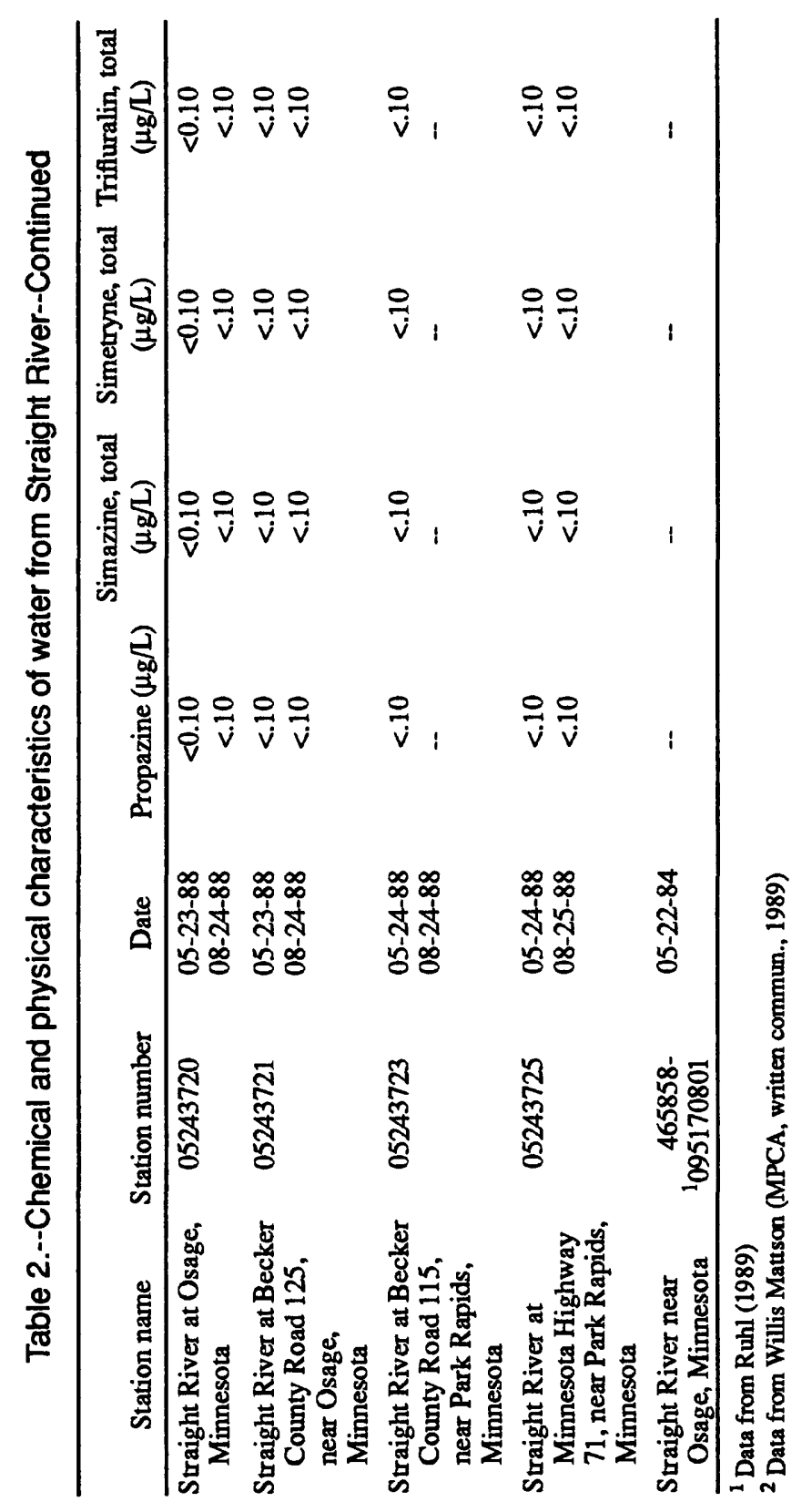


residence time of open water, and on the type and extent of vegetation along the stream. Net incoming radiation also is significantly affected by cloud cover.

Stream temperatures were measured continuously during May 1988 through August 1989 at four sites (A, B, $D$, and F). Representative results are shown for site $B$ on figure 9. This figure also summarizes air temperature, stream and ground-water temperature, and the relation between hydraulic head in the stream and in wells screened at different depths near the stream. These data generally are representative of conditions at other sites where data were collected.

Air temperature during the period ranged from a high of about $40^{\circ} \mathrm{C}$ to a low of about $-35^{\circ} \mathrm{C}$. Daily fluctuations in air temperature averaged about $25^{\circ} \mathrm{C}$. The magnitude of daily and seasonal stream-temperature fluctuations were not as great as temperature fluctuations of air. Stream-water temperature ranged from a high of about $28^{\circ} \mathrm{C}$ in summer to a low of about $0^{\circ} \mathrm{C}$ in winter. Daily fluctuations in stream temperature were about $15^{\circ} \mathrm{C}$ in summer. In winter, while the stream is ice-covered, the water temperature remained at about $0^{\circ} \mathrm{C}$. Figures 10 and 11 illustrate the variability in stream temperature at sites $A$ and $F$ during January 1989 , and sites A and B during July 1988. Figure 12 illustrates the variability in stream temperature at sites A, B, D, and F during July 1988. The stabilizing effect of the release of water at Straight Lake is shown at site $\mathrm{A}$ in figure 12.

\section{Daily variability in stream-water quality}

On July 12 and 13, 1988 measurements of $\mathrm{pH}$, air temperature, water temperature, and dissolved oxygen were made at about one-hour intervals at several locations on the stream. Figure 13 illustrates daily changes in these field measurements at sites $A$ and $F$. The graph of site $F$ is similar to data collected from sites $B$ and $D$ during this period. Data from site $A$ is significantly different from the others because it is influenced by the reservoir at the outlet of Straight Lake.

The plot of temperature data from site $F$ shows daily fluctuations caused by solar radiation, evaporation, and contact with warm air. The stream reaches its warmest temperature at about 1700 hours. After this maximum, the water becomes cooler as it loses heat to the atmosphere by radiation until about 0800 hours, when the daily cycle is repeated.

The graph of dissolved oxygen concentrations and $\mathrm{pH}$ also show daily fluctuations. These fluctuations are influenced by alternating photosynthesis and respiration of aquatic plants. Dissolved oxygen and $\mathrm{pH}$ reach their maximums shortly after solar radiation reaches its maximum and oxygen from photosynthesis has accumulated. Minimum values of dissolved oxygen and $\mathrm{pH}$ were measured at about sunrise, when respiration has utilized the maximum amount of accumulated oxygen.

Figure 14 illustrates data obtained at 2-hour intervals at sites A, B, D, and F. Little of the variation in stream temperature and dissolved oxygen exhibited at the other sites is evident at site A because of the moderating affect of the reservoir. Figure 14 also shows the downstream daily changes in stream temperature and dissolved oxygen at sites A, B, D, and F during July 12-13, 1988 , and illustrates that temperature and dissolved oxygen of water at sites B, D, and F have similar trends, but vary in magnitude among sites.

\section{Water Quality and Quantity for Trout Habitat}

Trout generally need water of better quality than is needed for most fish. Brook trout (Salvelinus fontinalis Mitchill) are not found in the Straight River, but were common in the stream as late as the 1940's (Dennis Ernst, Minnesota Department of Natural Resources, written commun., 1990). Brook trout require clear, cold waters with a silt-free, rocky substrate (Raleigh, 1982), and do not thrive where the water temperatures exceed $20^{\circ} \mathrm{C}$ for extended periods. Brook trout are tolerant of stream $\mathrm{pH}$ conditions from 3.5 to 9.8 and to a wide range of alkalinity and specific conductance. Optimum oxygen levels for brook trout are greater than $7 \mathrm{mg} / \mathrm{L}$ at temperatures less than $15^{\circ} \mathrm{C}$, and greater than $9 \mathrm{mg} / \mathrm{L}$ at temperatures greater than $15^{\circ} \mathrm{C}$ (Raleigh, 1982).

Stream temperature appears to be a limiting variable for trout in the Straight River. The stream probably is now too warm for the reproduction of brook trout, and may be near the upper limit for the maintenance of brown trout. Reduction in stream discharge also could degrade the habitat for trout in summer, further reducing the population of trout in the stream (Dennis Ernst, oral commun., 1990). Stream habitat for trout does not seem to be limited with respect to dissolved oxygen, even during summer.

\section{Ground Water}

Glacial deposits were divided into the following four hydrogeologic units for this investigation (fig. 2): (1) sand and gravel (outwash) deposits at or near land surface (surficial aquifer), (2) till and lake deposits (confining units) that separate the uppermost confined-drift aquifer and the overlying surficial aquifer, (3) buried sand and gravel deposits (uppermost confined-drift aquifer), and (4) glacial till or lake deposits exposed at land surface. 

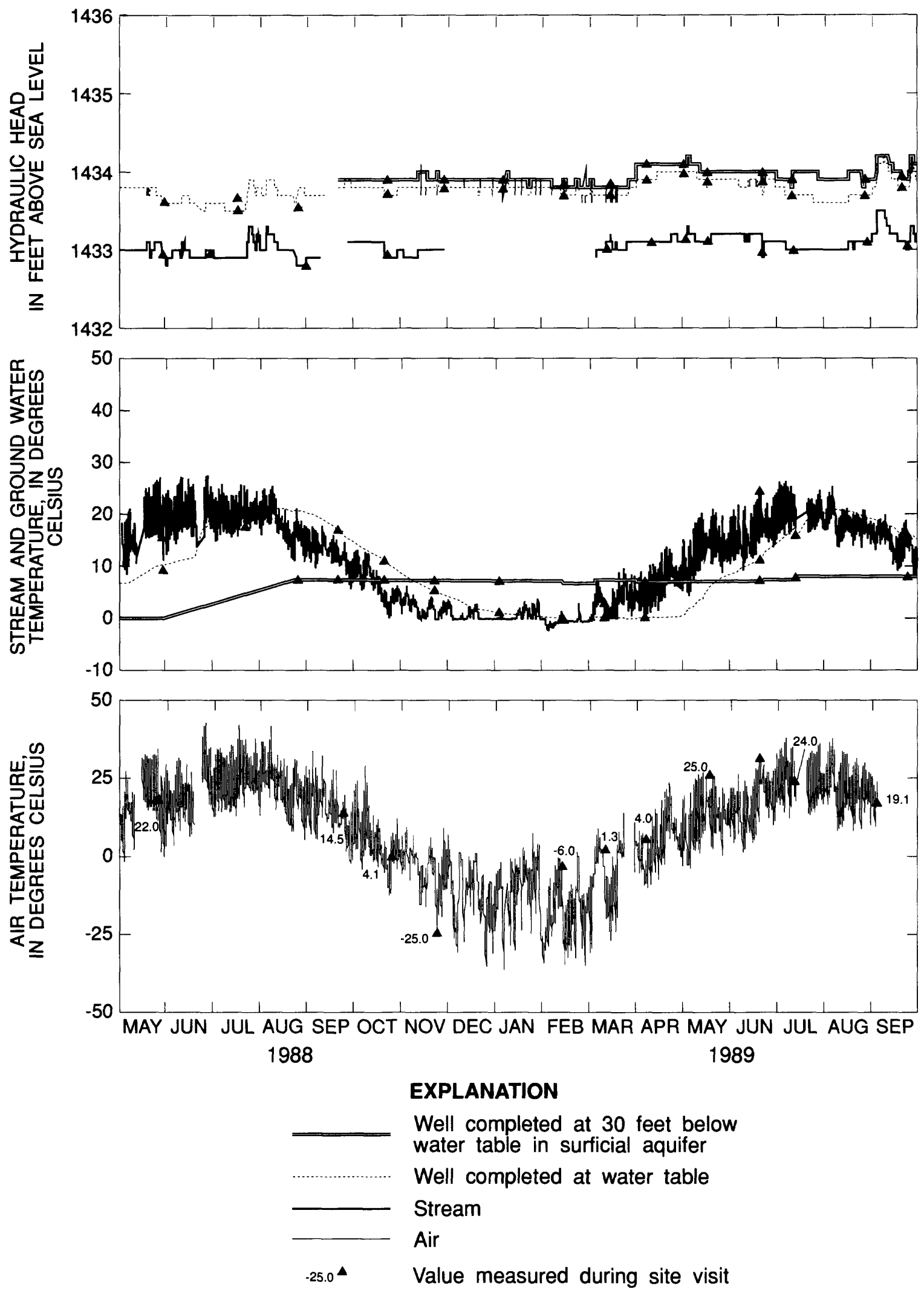

Figure 9.--Variability of temperature of air, stream and ground water, and hydraulic head of ground water and of the Straight River at Becker County Road 125 (site B), May 1988 through August 1989. 

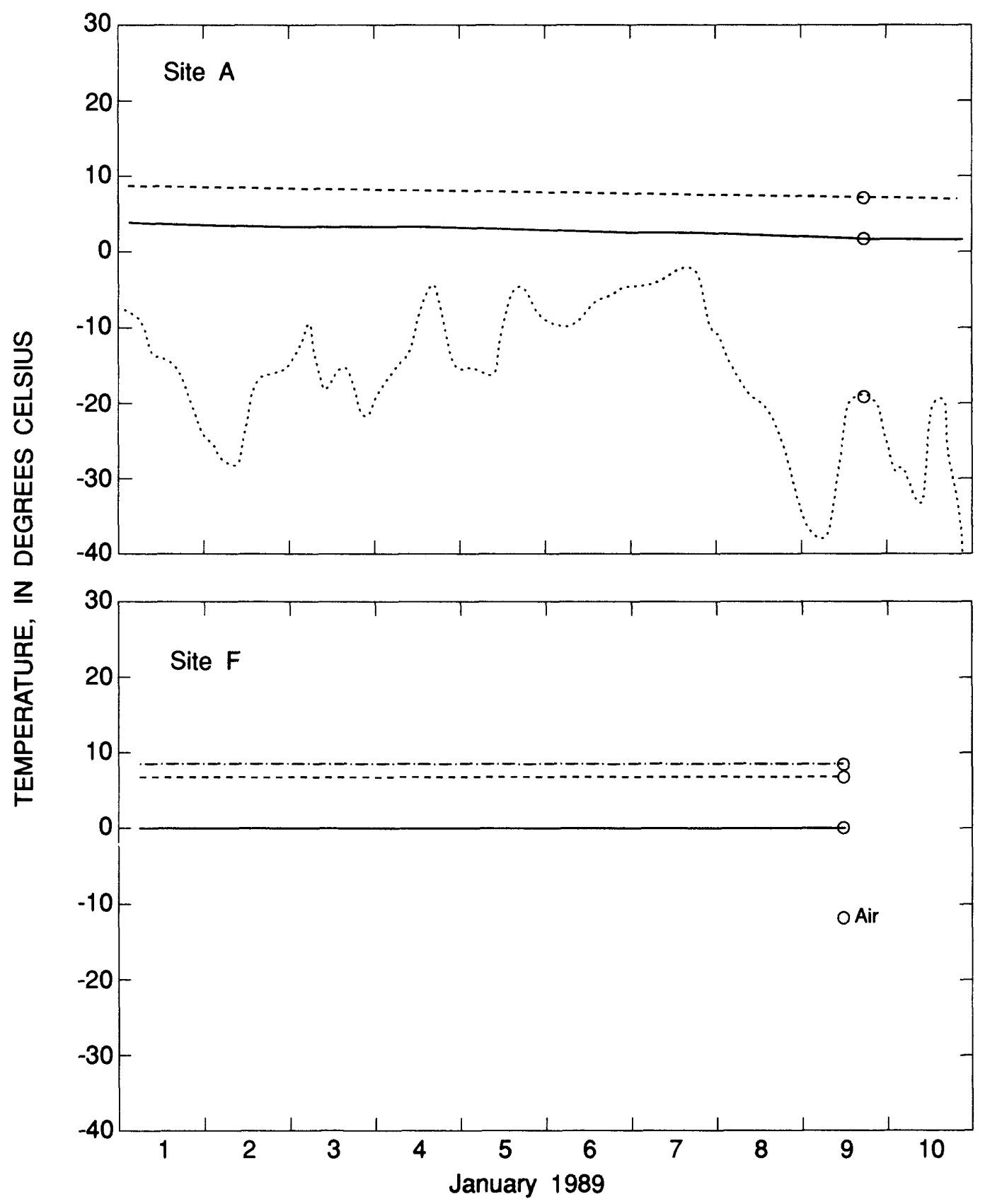

\section{EXPLANATION}

....... Well Completed at 20 feet below water table

Well completed at water table

- Stream

Air

- Temperature measured during site visit

Figure 10.--Variability of air, stream, and ground-water temperature at Osage, Minnesota (site A) and at U.S. Highway 71 near Park Rapids, Minnesota (site F) during January 1989. 


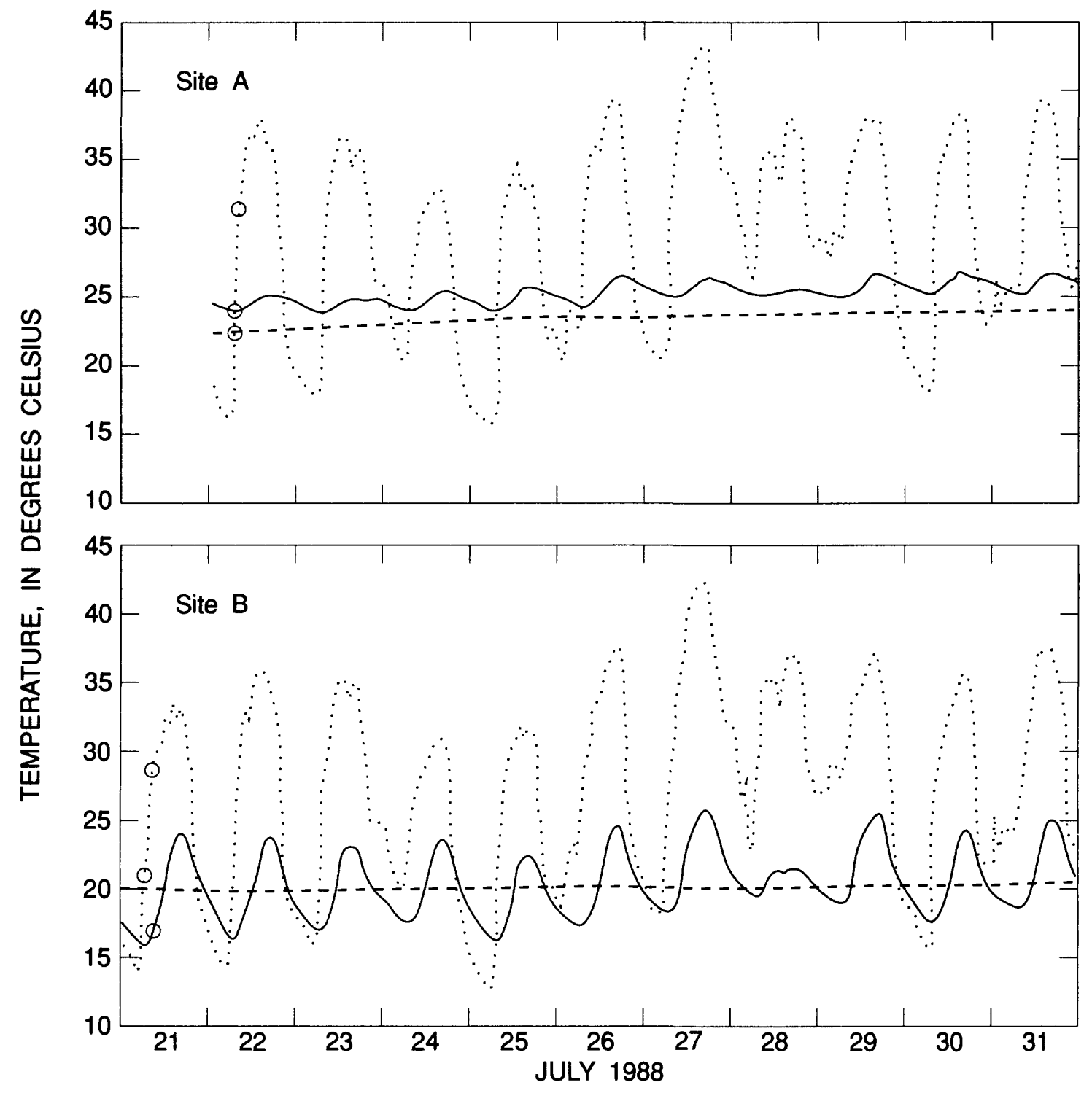

EXPLANATION

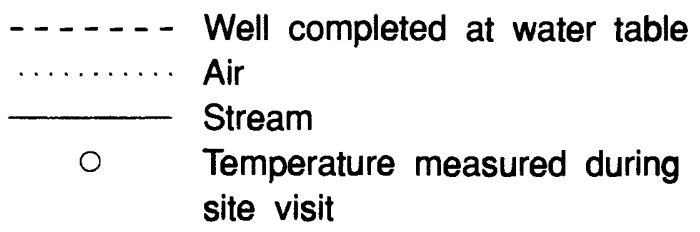

Figure 11.-Variability of air, stream, and ground-water temperature at Osage, Minnesota (site A), and at Becker County Road 125 near Osage, Minnesota (site B) during July 1988. 


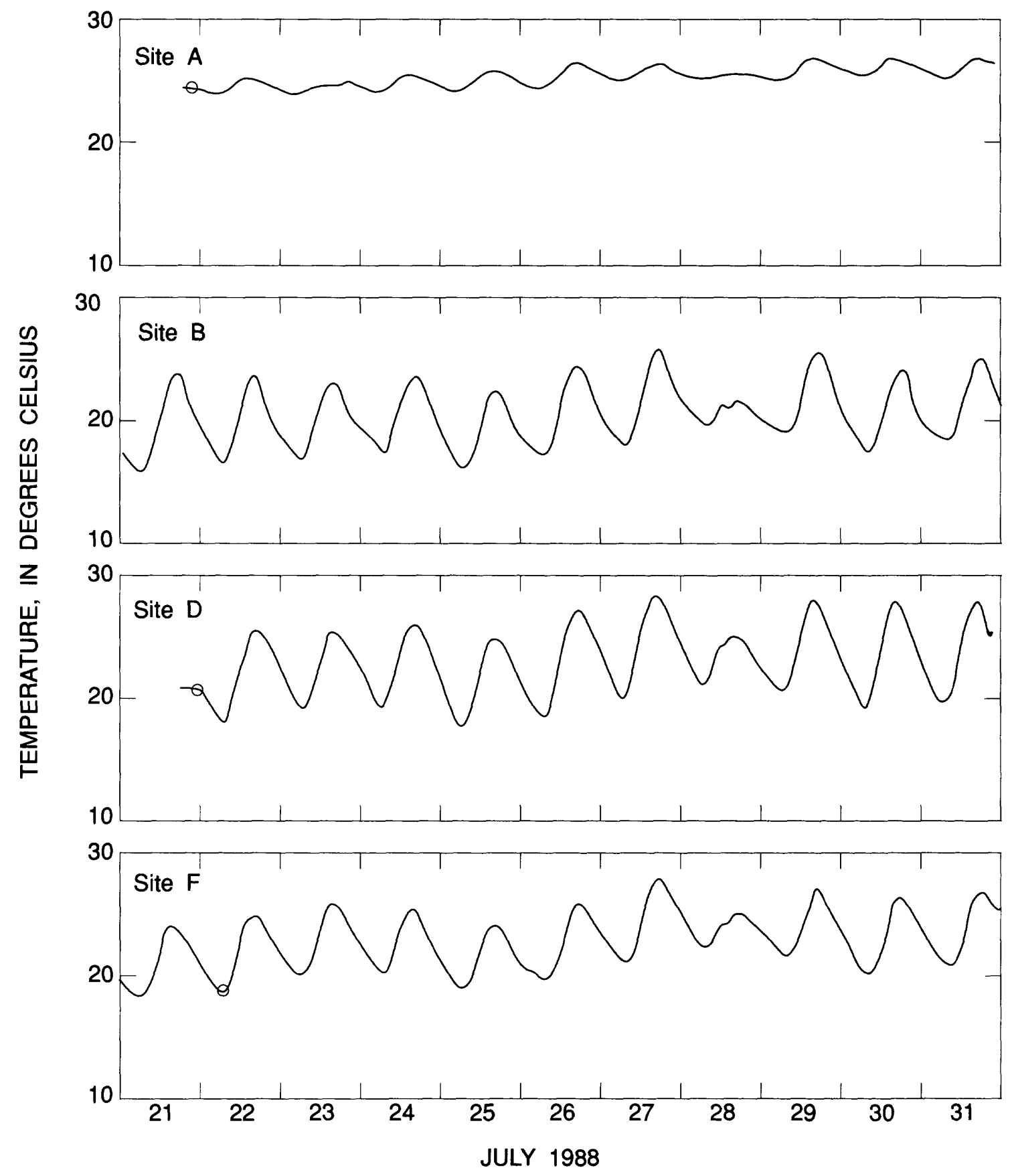

EXPLANATION

Temperature measured during site visit

Figure 12.--Variability of stream temperature in Straight River (sites A, B, D, and F) during July 1988. 


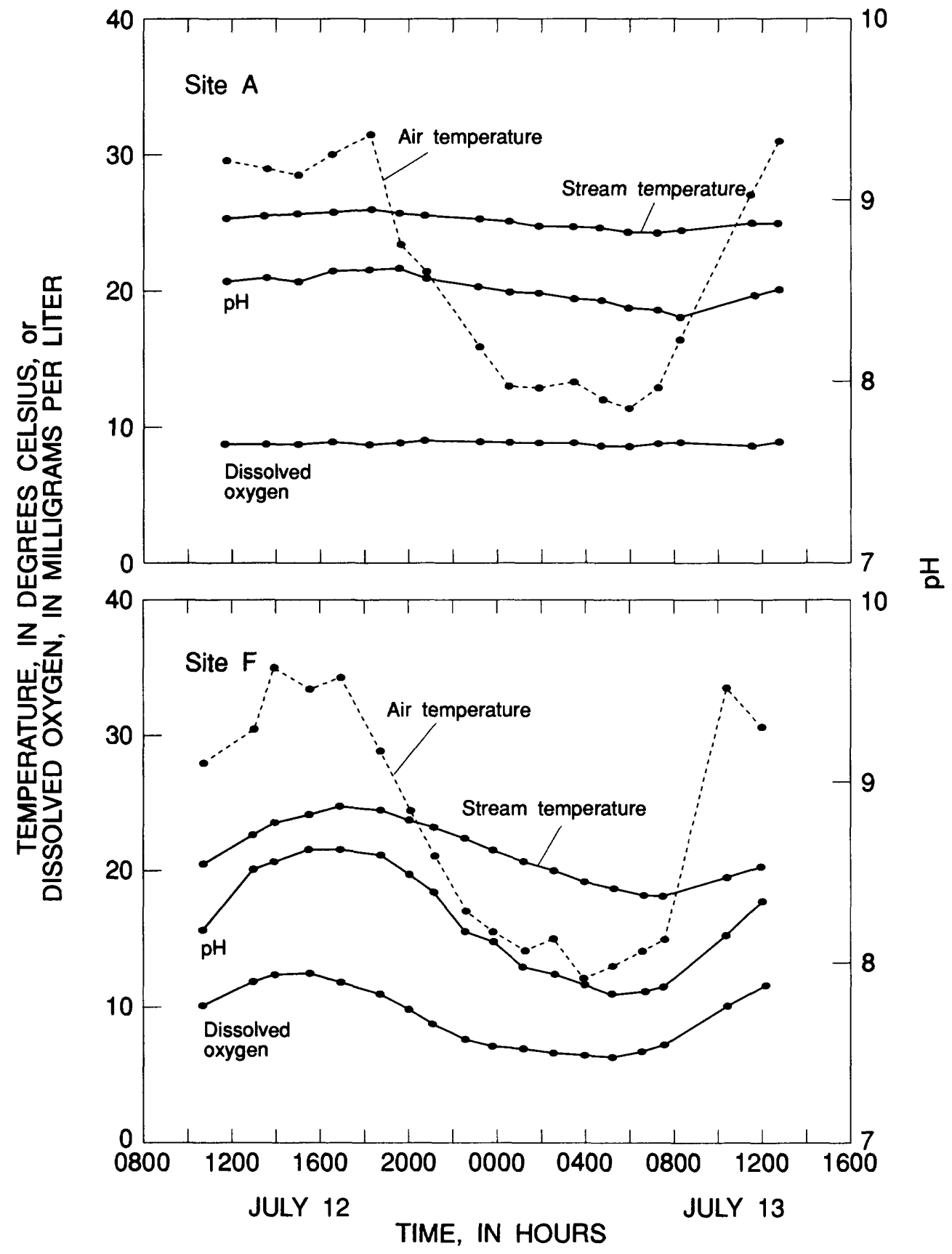

Flgure 13.--Variability of $\mathrm{pH}$, air and stream temperature, and dissolved oxygen of Straight River at Osage, Minnesota (site A), and at U.S. Highway 71 near Park Rapids, Minnesota (slte F) July 12-13, 1988. 

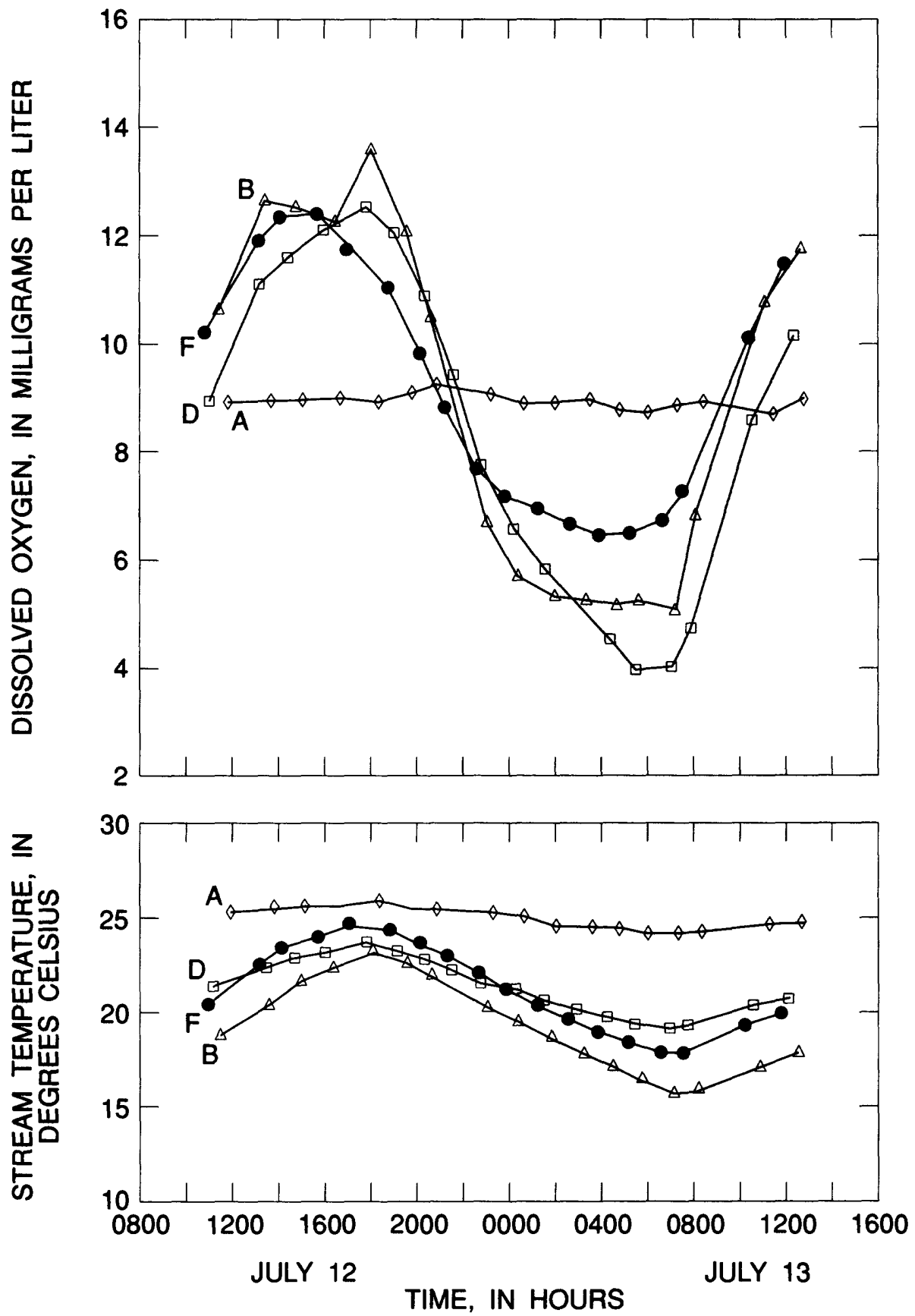

Figure 14.--Variability of stream temperature and dissolved oxygen of Straight River (sites A, B, D, and F), July 12-13, 1988. 
Surficial and confined-drift aquifers have hydrologically distinct characteristics. Surficial aquifers have an unsaturated zone above the water table. They generally yield large quantities of water to wells and pumping causes small declines in available head. Surficial aquifers are recharged rapidly and thus are susceptible to contamination from the land surface. Confined-driftaquifers are fully saturated and are isolated from land surface by one or more confining units. Pumping from wells completed in confined-drift aquifers generally causes greater declines in available head than does pumping surficial aquifers. Confined aquifers are recharged by leakage from overlying or underlying aquifers through confining units, and tend to be better protected from contamination by activities at the land surface.

The surficial aquifer (outwash) consists of sand and gravel. Either till deposited at the base of glaciers during glacial advances or glacial-lake deposits act as confining units. Till comprises unsorted clay, silt, sand, gravel, and boulders. Lake deposits generally consist of silt or clay. Till and lake deposits transmit only small quantities of water to wells. The uppermost confined-drift aquifer (outwash) also consists of sand and gravel overlain by till or lake sediments. The surficial and uppermost confineddrift aquifers are the major aquifers in the investigation area.

Other aquifers and confining units are present at depth throughout the entire thickness of the glacial drift in the investigation area. A $550 \mathrm{ft}$-deep well, located near the Straight River (T. 140 N., R. 35 W., sec. 31, CCC, Minnesota unique well no. 236103) penetrated eight thin water-bearing sand units below the uppermost confineddrift aquifer before penetrating Cretaceous bedrock at $435 \mathrm{ft}$ below land surface. Little data related to the units below the uppermost-confined aquifer are available because these units are not used extensively for water supply. The deeper units, therefore, are not considered in this report.

Discharge from the surficial aquifer is by outflow to the Straight River and to irrigation and domestic wells. Discharge from the surficial aquifer also occurs by evapotranspiration near lakes and rivers and near wetlands during the growing season where the water table is within the root zone of vegetation. Discharge from the uppermost confined-drift aquifer is by leakage through confining beds to the surficial aquifer. The average longterm potential evapotranspiration is 22 inches per year (Baker and others, 1979).

Ground-water discharge occurs as water flows from the surficial aquifer and discharges to the streams and lakes. Ground-water divides, which coincide roughly with topographic divides, separate ground-water-flow systems that discharge to the streams. The flow of ground water in the uppermost confined-drift aquifer is less affected by small streams, wetlands, and lakes than is the flow of water in the surficial aquifer.

\section{Surficial Aquifer}

The surficial aquifer is present in most of the investigation area(fig. 15). The aquifer consists of coarse sand and gravel in the north and finer sand and gravel to the south. Aquifer characteristics pertinent to evaluating ground-water flow include hydraulic conductivity, hydraulic gradient, transmissivity, areal extent, and storage. Data for wells completed in the surficial aquifer and used as data for this report are listed in table 11 in the Supplemental Information Section.

Horizontal hydraulic conductivity for the surficial aquifer was determined from a study of the Pineland Sands aquifer (Helgesen, 1977), and calibration of a ground-water-flow model developed as part of this investigation. Results of four aquifer tests in the Pineland Sands area (Helegesen, 1977) indicated that hydraulic conductivity of the surficial aquifer ranges from about 320 to $630 \mathrm{ft} / \mathrm{d}$ and storage coefficient ranges from 0.18 to 0.25 . An average value of hydraulic conductivity of 215 $\mathrm{ft} / \mathrm{d}$ was used in model simulations. This value provided the best match between computed and measured water levels for the aquifer. Hydraulic conductivity computed from aquifer tests may be increased as a result of production wells located in zones of higher-than-average hydraulic conductivity.

The top of the saturated part of the surficial aquifer is the water table (fig. 15), and the base of the aquifer is the top of the uppermost confining unit. The slope of the base of the surficial aquifer generally is complex, but slopes toward the east (fig. 16). The saturated thickness of the unconfined aquifer varies from 0 to greater than $80 \mathrm{ft}$, and exceeds $30 \mathrm{ft}$ over most of the investigation area. Unconfined conditions prevail except where thin clay, silt or peat beds cause confined conditions in scattered locations. The water table was mapped from water levels in approximately 155 wells measured several times during a two-year period. The general direction of ground-water flow and the elevation of the water table for each of these periods are similar to that shown in figure 15. The altitude of the water table ranges from about 1,480 to about $1,370 \mathrm{ft}$ above sea level and slopes regionally to the southeast at a gradient of about $10 \mathrm{ft} / \mathrm{mi}$ toward the Straight, Fishhook, and Shell Rivers, and locally to lakes, ponds, wetlands, and production wells. Depths to the water table below land surface range from 0 to about $30 \mathrm{ft}$. The ground-water basin roughly 


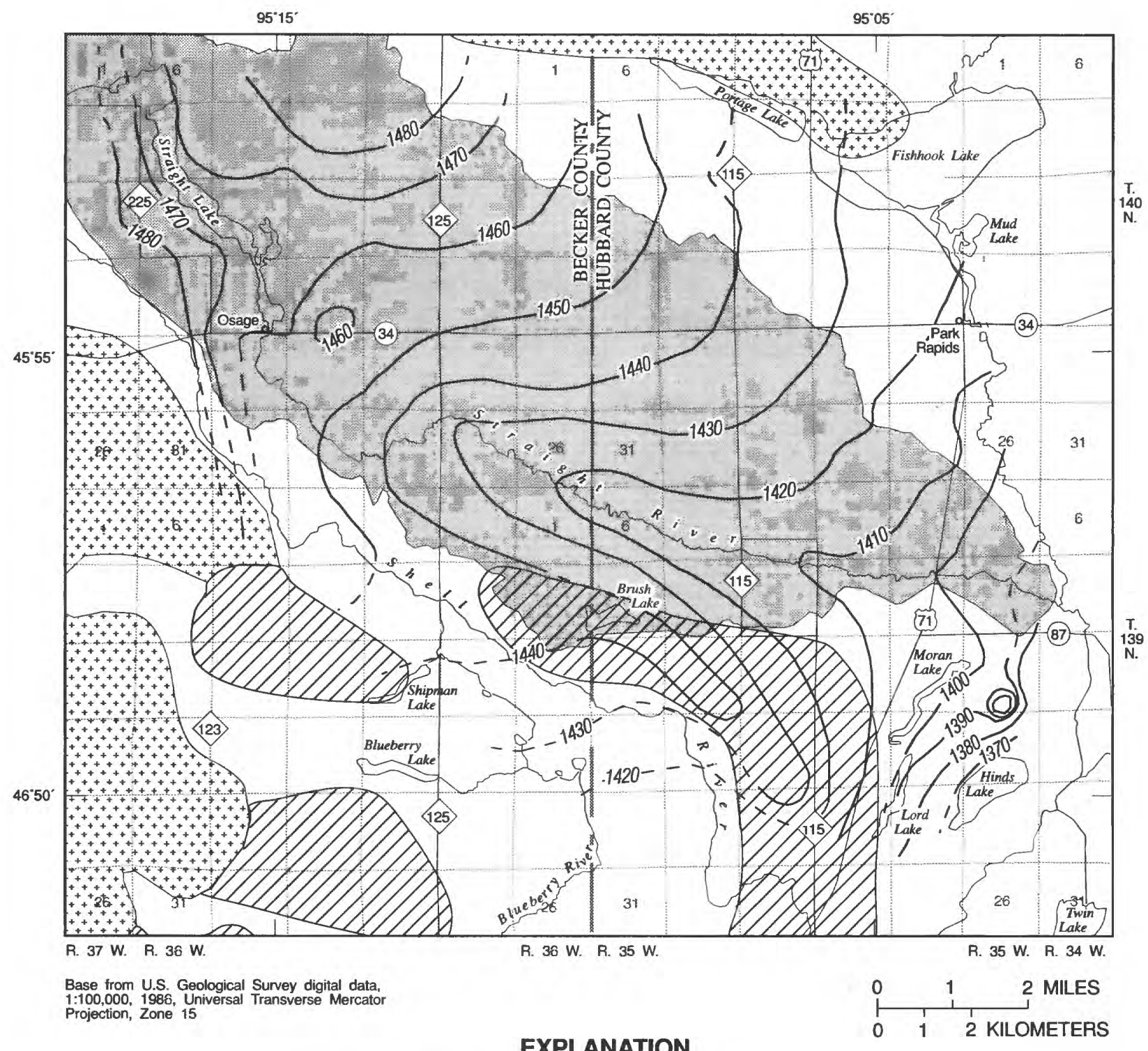

EXPLANATION

Straight River Basin

Surficial geology:

$\square$ Outwash plain

Glacial till (end moraine)

VII/A Glacial till (ground moraine)

- 1440 - Potentiometric contour--Shows altitude at which water level would have stood in tightly cased wells open to the surficial aquifer. Dashed where approximately located. Contour interval 10 feet. Datum is sea level.

Figure 15.--Altitude of potentiometric surface (water table) of surficial aquifer during August 1988. 


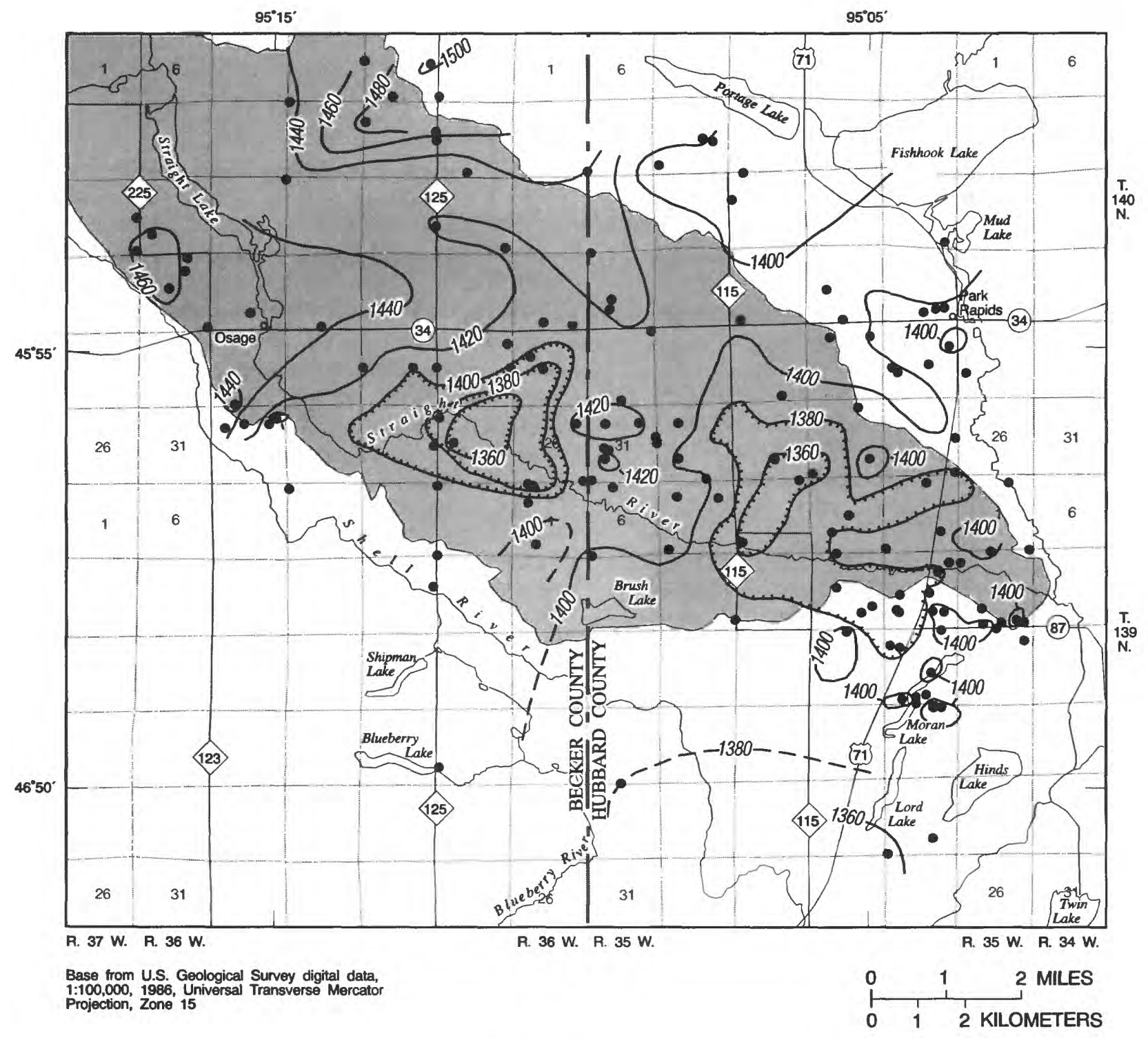

EXPLANATION

Straight River Basin

-1440 - Structure contour--Shows altitude of top

of uppermost confining unit. Dashed

where approximately located.

Contour interval 20 feet. Datum

is sea level.

Structure contour enclosing lower

altitude area of top of

uppermost confining unit.

- Observation well

Figure 16.-Altitude of the top of the uppermost confining unit. 
coincides with the surface-water basin, except in an area near the Shell River in the western part of the investigation area, where water levels from observation wells indicated that ground water flows beneath the Shell River and discharges into the Straight River.

With no withdrawals for irrigation, most ground-water discharge from the aquifer in the investigation area is to the streams and lakes. These areas of discharge are based on inferences made from potentiometric-surface maps and results of model simulations. Ground-water divides are inferred from data shown on figure 15. These divides separate ground-water-flow systems discharging to the streams.

Long-term water-level data are available from several observation wells screened in the surficial aquifer in the Straight River area. Data from these wells indicate that hydraulic head in the aquifer changed less than $2.0 \mathrm{ft}$ during the summer irrigation periods (April to September) of 1987-89 (fig. 17). Available data also indicate that ground-water levels in the surficial aquifer declined by as much as $8 \mathrm{ft}$ during 1985-88 (fig. 18), and that the seasonal change averaged about 1-2 feet during April through September 1987 (fig. 19). Each of these changes probably has occurred in response to a decrease in recharge from precipitation and an increase in groundwater withdrawals. Few long-term data, however, are available from wells to document the effects of groundwater withdrawals in the investigation area.

\section{Uppermost Confining Unit}

The surficial and uppermost confined-drift aquifers are hydraulically and physically separated by the uppermost confining unit, which consists of fine-grained glacial till or lake deposits. The top of the uppermost confining unit (also the bottom of the surficial aquifer) slopes generally to the southeast at a gradient of about $10 \mathrm{ft} / \mathrm{mi}$ (fig. 16). The thickness of the uppermost confining unit ranges from $10 \mathrm{ft}$ to more than $140 \mathrm{ft}$; the unit is continuous throughout the investigation area.

The thickness and vertical hydraulic conductivity of the uppermost confining unit and the differences in hydraulic head between the aquifers above and below the confining unit control the amount and direction of ground-water flow between the uppermost confined-drift aquifer and the surficial aquifer. The vertical hydraulic

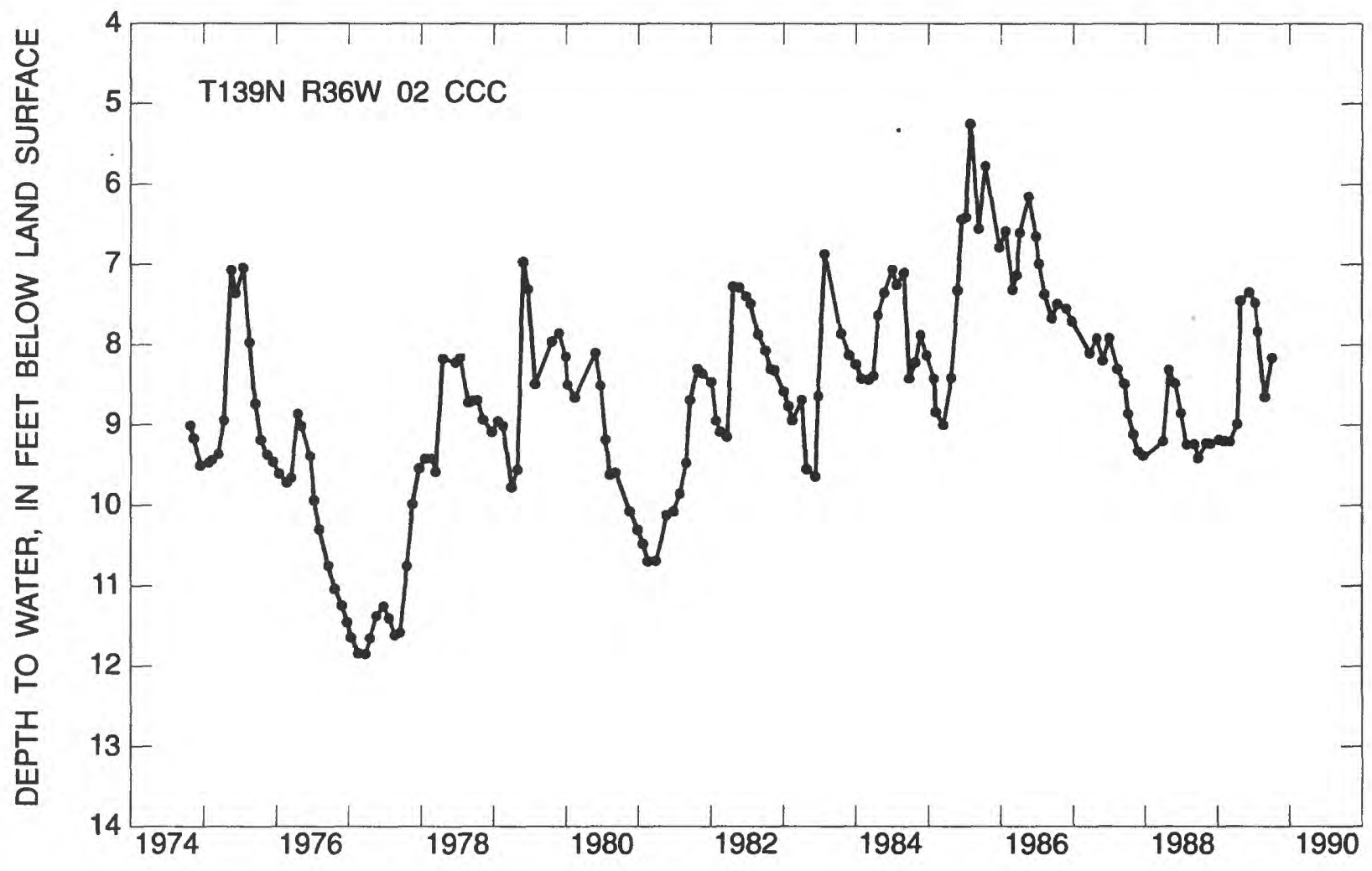

Figure 17.-Hydraulic head in Minnesota Department of Natural Resources well 3006 screened in the surficial aquifer, Becker County, during calendar years 1974 through 1989. 


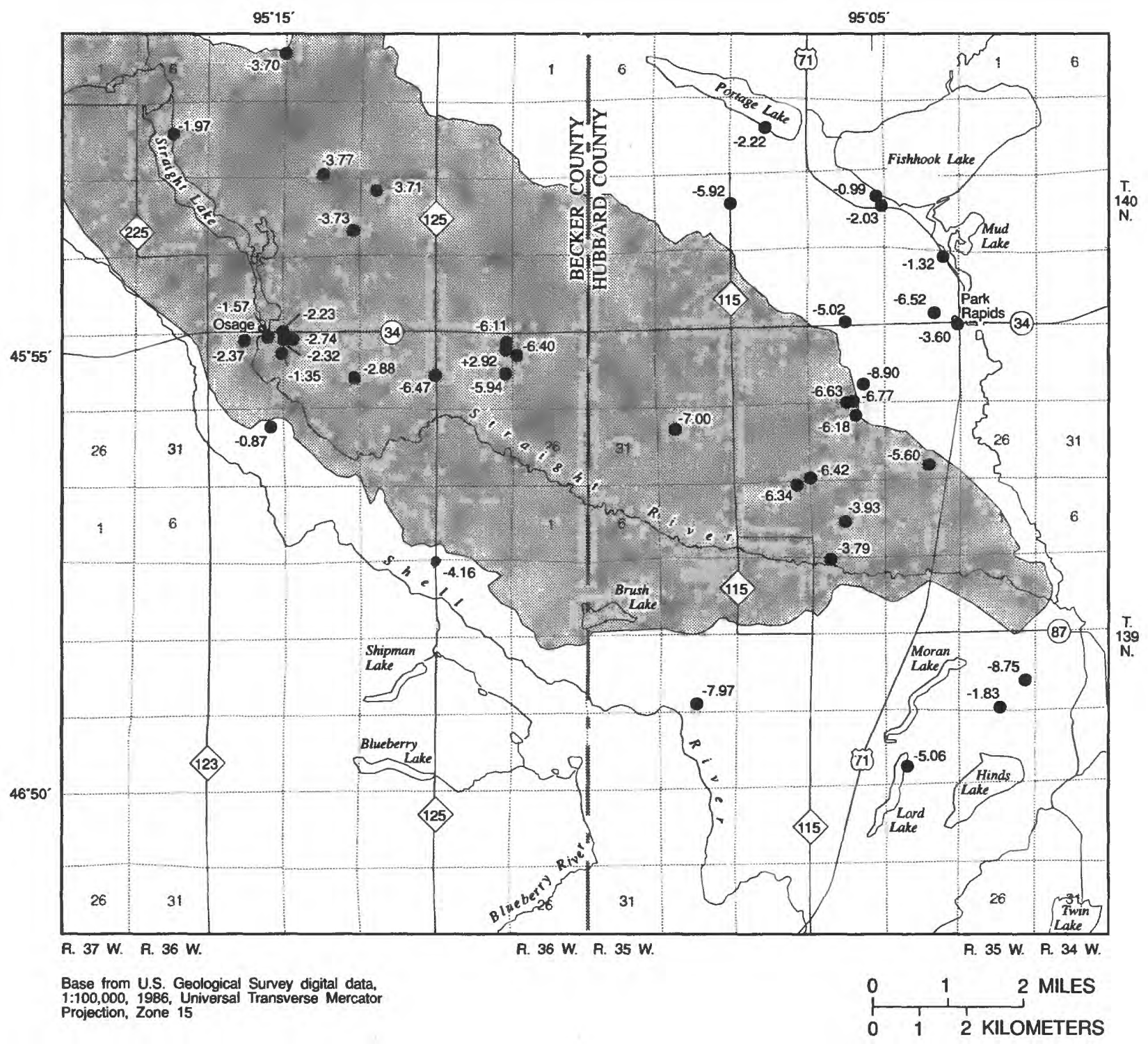

\section{EXPLANATION}

Straight River Basin

${ }^{2.05}$ Observation well--Number shows

water-level change.

Figure 18.--Change in hydraulic head in wells screened in the surficial aquifer, 1985-88. 


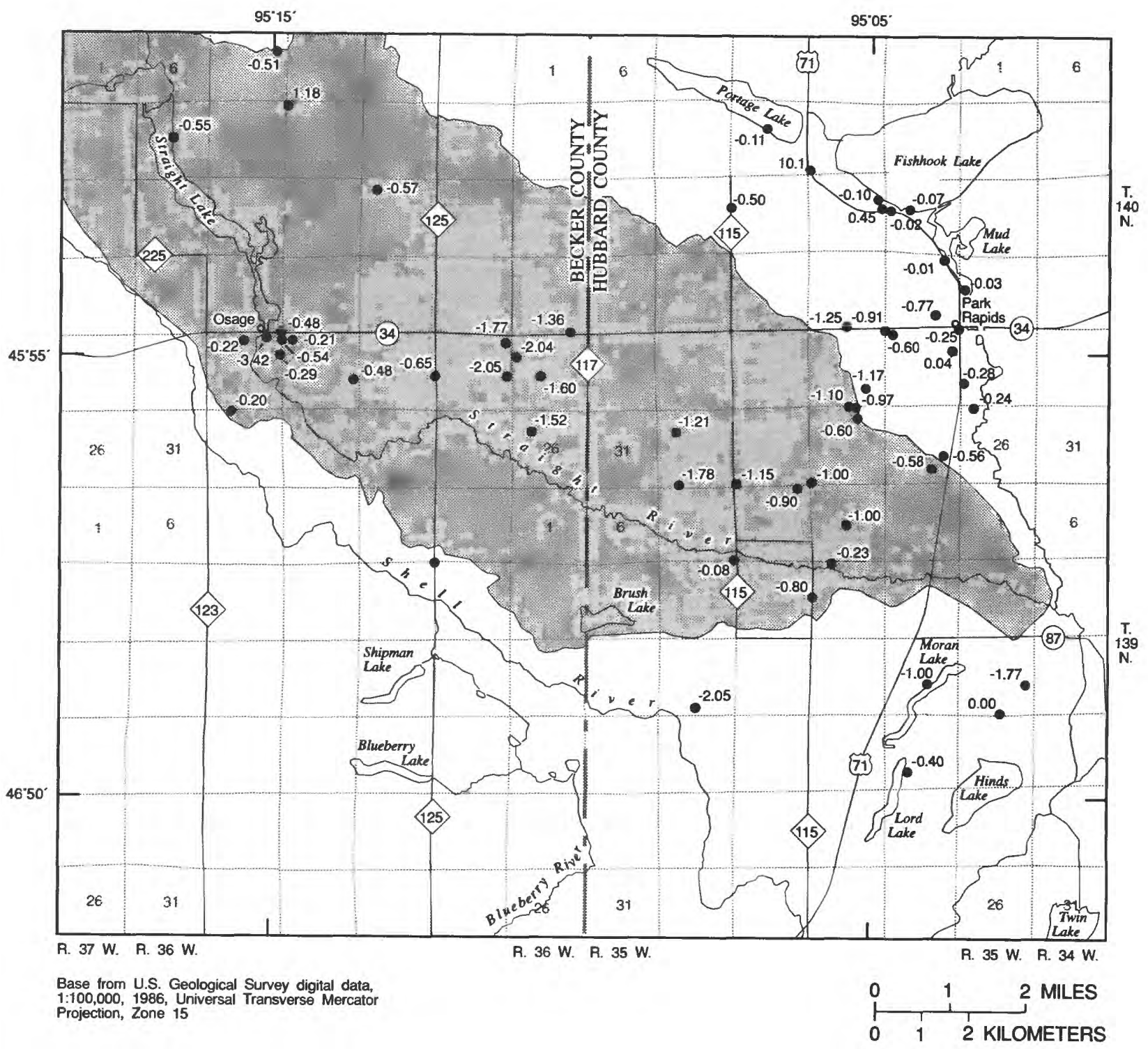

\section{EXPLANATION}

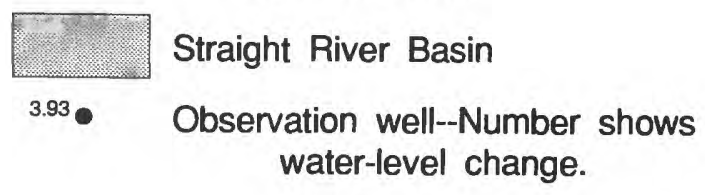

water-level change.

Figure 19.--Change in hydraulic head in wells screened in the surficial aquifer, April 1987 through September 1987. 
conductivity of till and glacial-lake deposits generally is muchlowerthan the vertical hydraulicconductivity of sand and gravel deposits. On the basis of analyses of 12 aquifer tests, Delin (1986) estimated the mean vertical hydraulic conductivity of till in the area of Morris, Minnesota, to be $2.5 \times 10^{-2} \mathrm{ft} / \mathrm{d}$. This is similar to the value of $1.8 \times 10^{-2}$ $\mathrm{ft} / \mathrm{dfor}$ the DetroitLakes area of Minnesota (Miller, 1982). These values of vertical hydraulic conductivity, which are higher than those reported for other parts of the glaciated northern United States, reflect the sandy nature of till in the investigation area.

Model analysis for this investigation indicated that a value of $0.2 \mathrm{ft} / \mathrm{d}$ is reasonable for vertical hydraulic conductivity for the uppermost confining unit in the investigation area. Although water flows between the surficial and confined-drift aquifers on a regional scale, the confining unit serves locally in the investigation area as a barrier to the rapid exchange of ground water between the aquifers.

\section{Uppermost Confined-Drift Aquifer}

The uppermost confined-drift aquifer is assumed to be continuous in the investigation area (fig. 20). Data for wells completed in the uppermost confined-drift aquifer and used as data for this report are listed in table 12, in the Supplemental Information Section. The thickness of the aquifer ranges from 10 to $75 \mathrm{ft}$ (fig. 21). The uppermost confined-drift aquifer is the primary source of ground water to wells in the Straight River area.

Model calibration indicated that a reasonable average value of hydraulic conductivity for the aquifer would be about $300 \mathrm{ft} / \mathrm{d}$. Use of this value in calculations yields a transmissivity of the aquifer from less that $300 \mathrm{ft}^{2} / \mathrm{d}$ (square feet per day) to greater than $22,500 \mathrm{ft}^{2} / \mathrm{d}$.

Analysis of geologic, water-table, and potentiometricsurface data of the aquifers indicate that the surficial and uppermost confined-drift aquifers may be hydraulically connected in the Straight River area. The direction of ground-water flow in the uppermost confined-drift aquifer is toward the Straight, and Fishook Rivers (fig. 22).

Long-term water-level fluctuations in well T. $140 \mathrm{~N}$., R. 35 W. Sec 28, DCC, (DNR Minnesota unique well no. 139200) screened in the uppermost confined-drift aquifer, shows a $7.63 \mathrm{ft}$ water-level decline during 1987 through 1989 (fig. 23). The decline is probably caused by below average precipitation and above average ground-water withdrawals. Figure 24 shows the change in the waterlevel during November 1985 (a period of above-normal precipitation) through September 1988 (a period of below-normal precipitation). Water-level declines were as large as $16 \mathrm{ft}$ near areas of irrigation. The water-level declines during 1985 to 1988 probably occurred in response to changes in recharge from precipitation and from ground-water withdrawal.

\section{Water Quality}

Chemical constituents dissolved in ground water are derived mainly from mineral-water interaction as the water flows through soil, glacial drift, and rock. Groundwater quality varies in response to changes in residence time, length of flow path, temperature, precipitation, and chemical reactions with soils, minerals, and aquifer materials. Ground-water quality also can be influenced by chemicals introduced to aquifers by human activities. Chemical constituents naturally present in ground water can, in some instances, be the same as those introduced by human activities. For example, chloride is derived naturally from chloride-bearing minerals, but also can be introduced to ground-water systems from human and animal wastes and by leaching from chemicals.

Chemicals may be introduced directly into the groundwater system by accidental spills or by leaking storage tanks that discharge to the ground-water system, or from nonpoint sources related to land-use activities such as the application of pesticides and herbicides.

Water samples were collected from observation wells, domestic wells, and irrigation wells completed in the surficial and uppermost confined-drift aquifers. These samples were used to determine general ground-water quality, and to provide baseline hydrologic and waterquality data for use in future assessments of long-term trends.

\section{General chemical quality}

Calcium and bicarbonate are the predominant chemical constituents in water from surficial and the uppermost confined-drift aquifers (tab. 3 ). The percentage of total milliequivalents per liter of major constituents in water from the aquifers and from the Straight River are shown in figure 25. The points representing cation and anion data from the lower triangles are extended to the Piper diagram (Freeze and Cherry, 1979) to describe the general type of water indicated by concentrations of cations and anions. Calcium and bicarbonate are derived primarily from soil and rock weathering (Hem, 1985). Water from both aquifers generally is suitable quality for domestic and irrigation use (tab. 4).

Water from both surficial and uppermost confined-drift aquifers in the Straight River area is hard. Hardness generally is associated with the effects observed with the use of soap or with encrustations left by water that has 


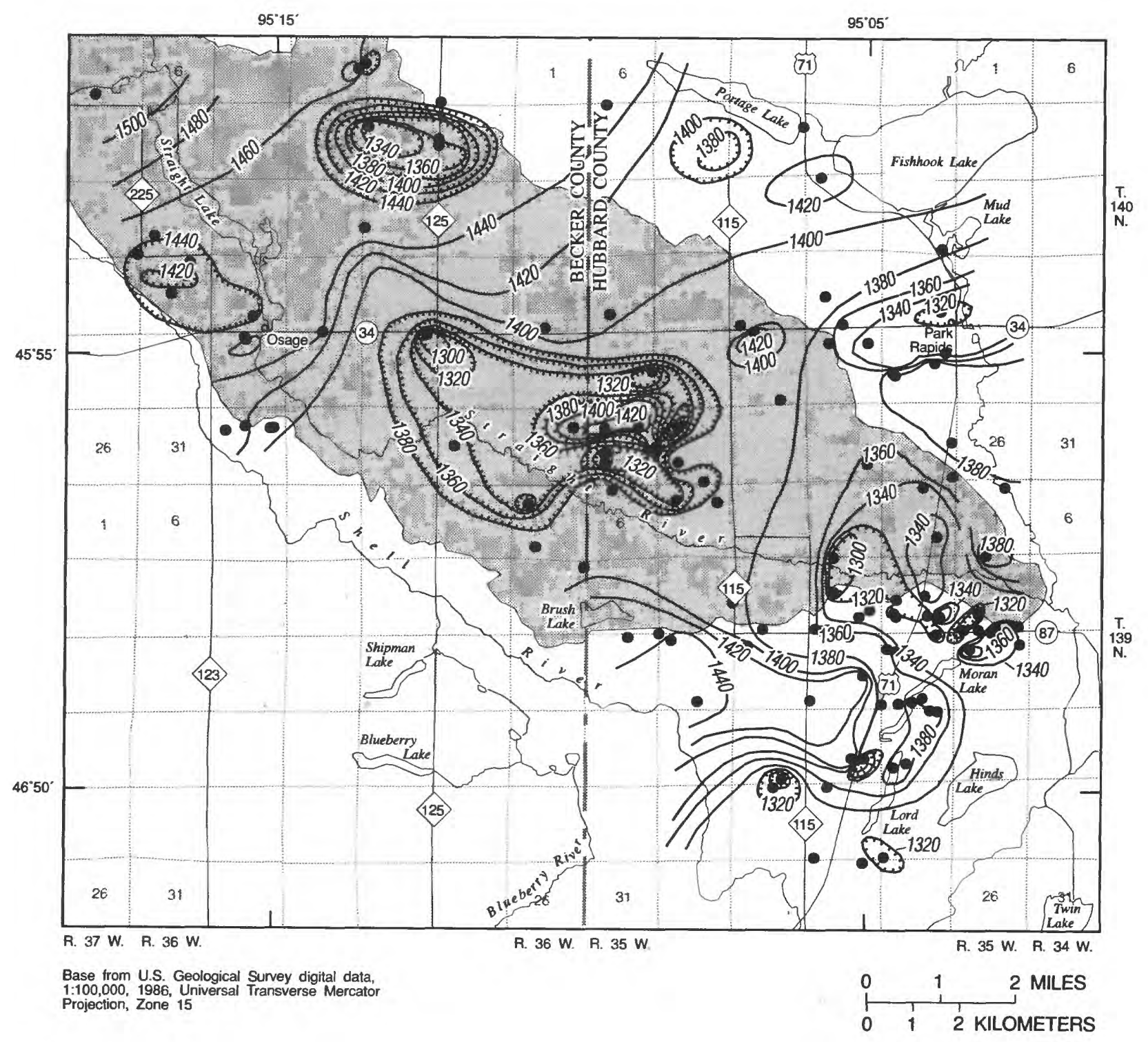

\section{EXPLANATION}

Straight River Basin

- 1440 - Structure contour--Shows altitude

of top of uppermost confined-drift

aquifer. Hachures indicate depression.

Contour interval in feet. Datum is sea level.

- Observation well

Figure 20.--Altitude of the top of uppermost confined-drift aquifer. 


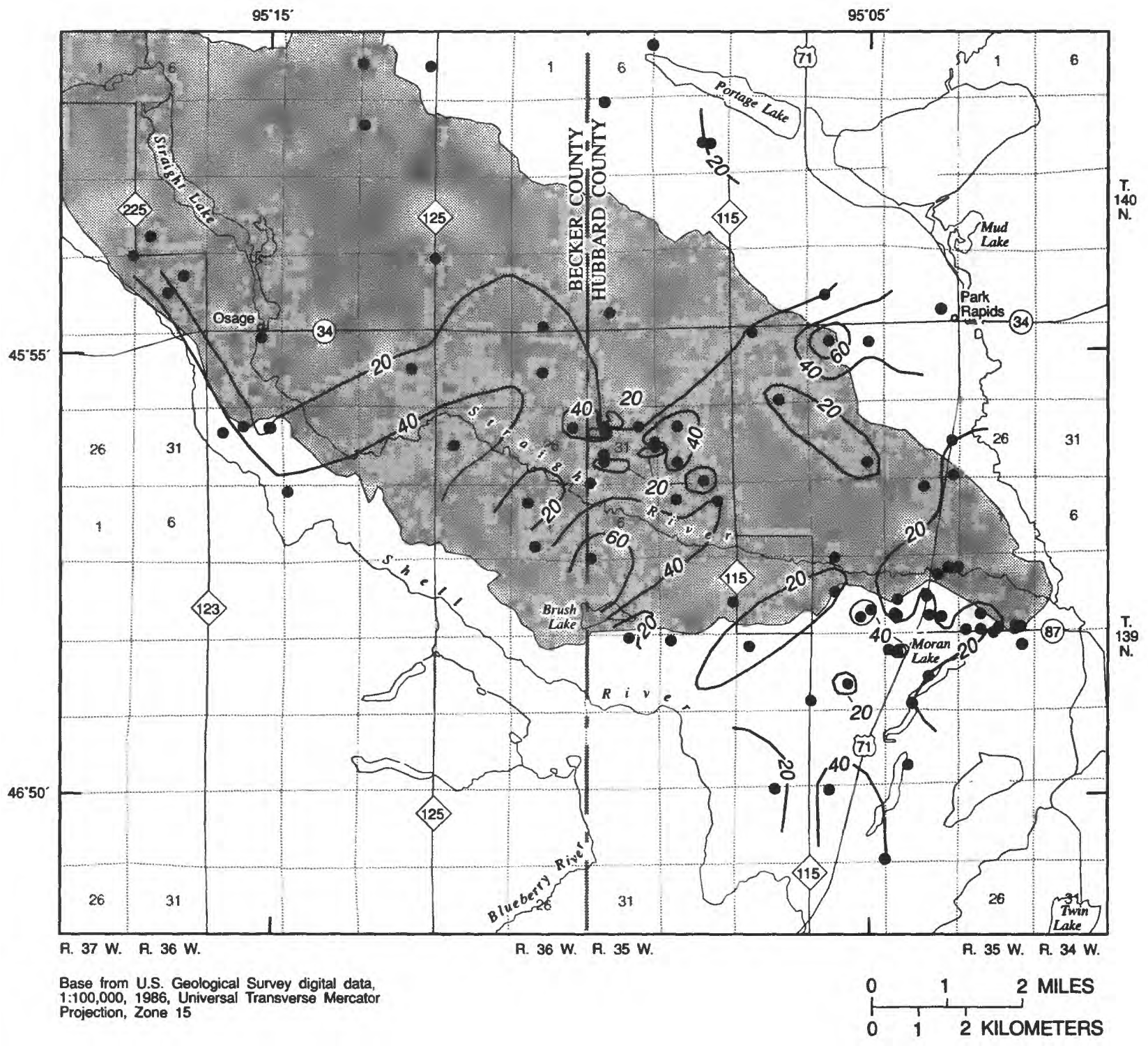

\section{EXPLANATION}

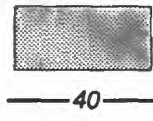

Straight River Basin

Line of equal thickness of uppermost confined-drift aquifer. Interval 20 feet.

- Observation well

Figure 21.--Thickness of the uppermost confined-drift aquifer. 


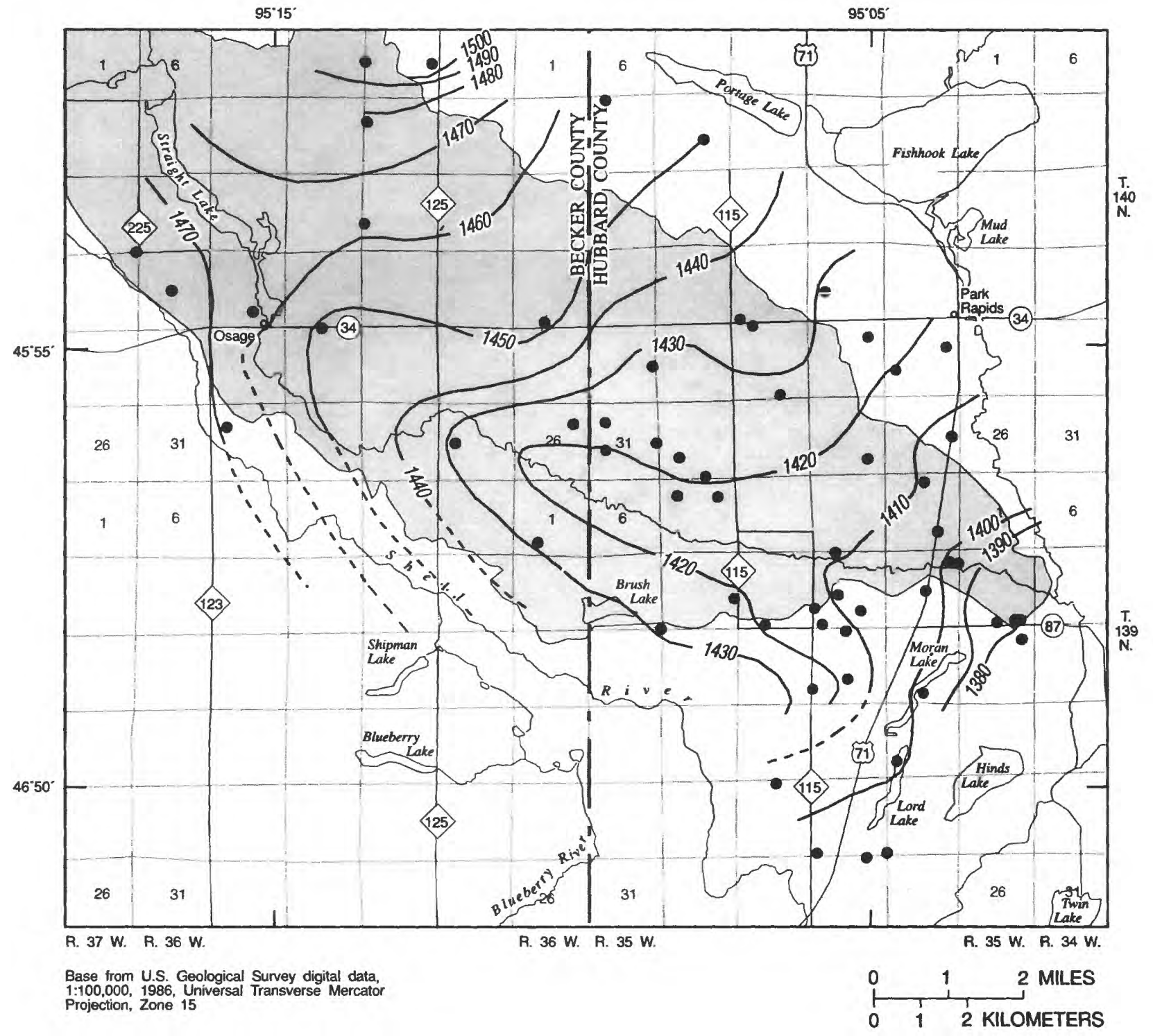

\section{EXPLANATION}

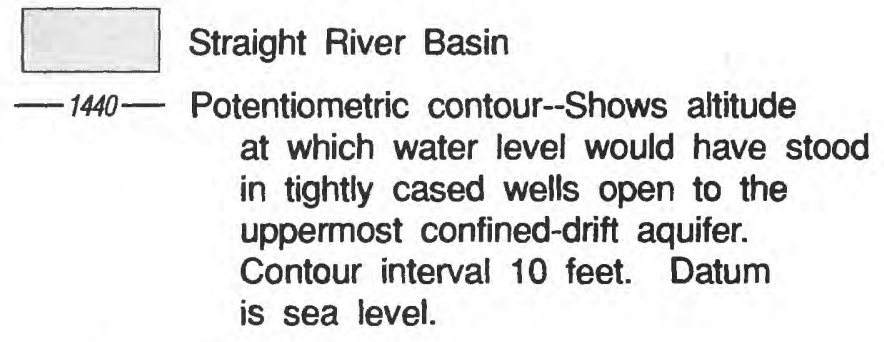

- Observation well

Figure 22.--Altitude of potentiometric surface of the uppermost confined-drift aquifer during August 1988. 


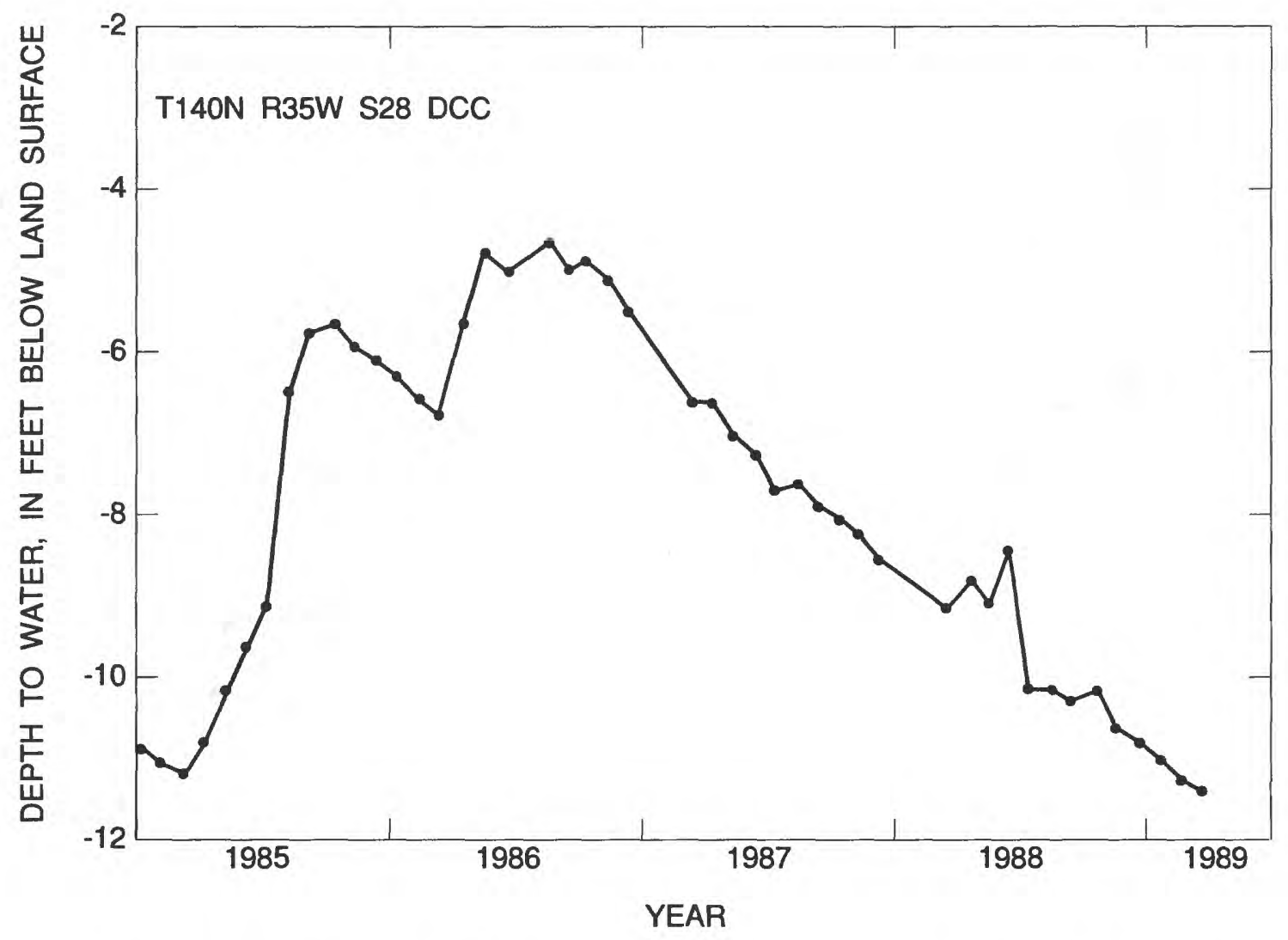

Figure 23.--Water level in Minnesota unique well number 139200 screened
in the uppermost confined-drift aquifer, during calendar years 1985-89.

evaporated. The reactions with soap result from cations that form insoluble compounds with soap. Because hardness is a property attributed to more than one constituent (mainly calcium and magnesium), the convention of reporting hardness in terms of an equivalent concentration of calcium carbonate generally is used (Hem, 1985).

Nitrate (nitrite plus nitrate as $\mathbf{N}$ ) concentrations in water from some shallow wells completed near the water table exceed the limit set by the MPCA (1988) drinking water standards (fig. 26). Concentrations of nitrate in water from wells with screens completed at the water table generally are greater than in wells with screens completed below the water table. Pesticides were only detected in samples of ground water from one well (tab. 3).

Nitrate contamination can result from infiltration of runoff from livestock feedlots, domestic septic systems, and fertilizers. Studies conducted by Myette (1984) near Staples, Minnesota, indicate that nitrate and chloride generally were largest in the surficial aquifer near the water table. Water containing increased levels of nitrate and chloride likely infiltrates to the water table, moves laterally along flow paths and discharges to streams and lakes. A minor amount of vertical mixing appears to occur within the saturated part of the surficial aquifer.

\section{Temperature}

Ground water in the surficial aquifer and in the uppermost confined-drift aquifer has a relatively constant temperature of about $7^{\circ} \mathrm{C}$. Ground-water temperatures are more variable near the water table, where temperature is affected by percolation of recharge. Ground-water temperature varies from less than $6.5^{\circ} \mathrm{C}$ to about $9^{\circ} \mathrm{C}$ during the year, and increases slightly with depth due to the geothermal gradient.

Figure 27 shows ground-water temperature and water levels in wells at irrigated and nonirrigated sites. Data are from wells screened near the water table, near the bottom of the surficial aquifer, and in the uppermost confineddrift aquifer. Ground-water temperature in irrigated areas generally was less than one degree higher than in nonirrigated areas. The temperature differences also may be related to the depth to the water table, which is several 


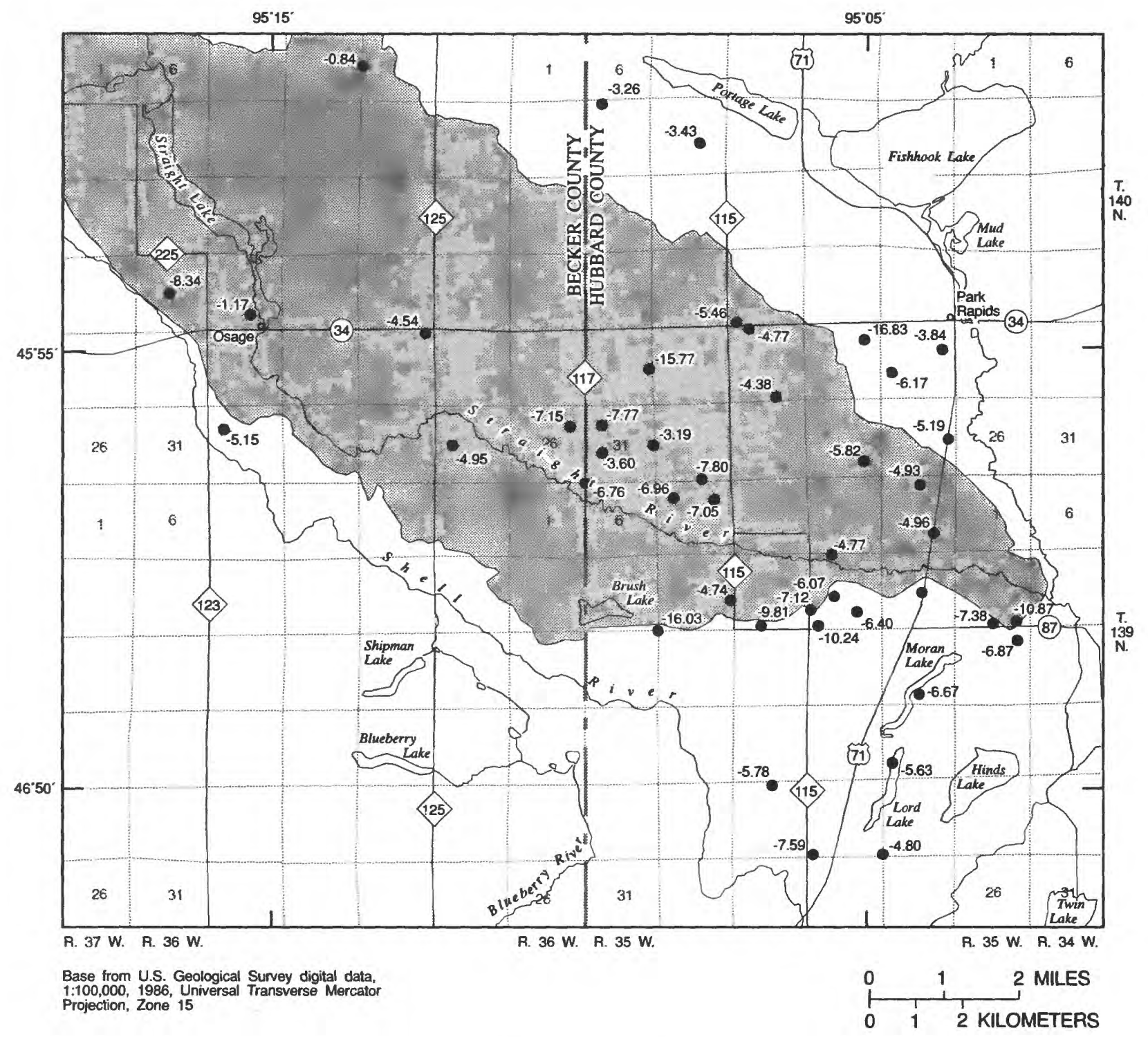

\section{EXPLANATION}

Straight River Basin

-7.15. Observation well--Number shows

change in hydraulic head, in feet.

Figure 24.--Change in hydraulic head in wells screened in the uppermost confined-drift aquifer, November 1985 through September 1988. 


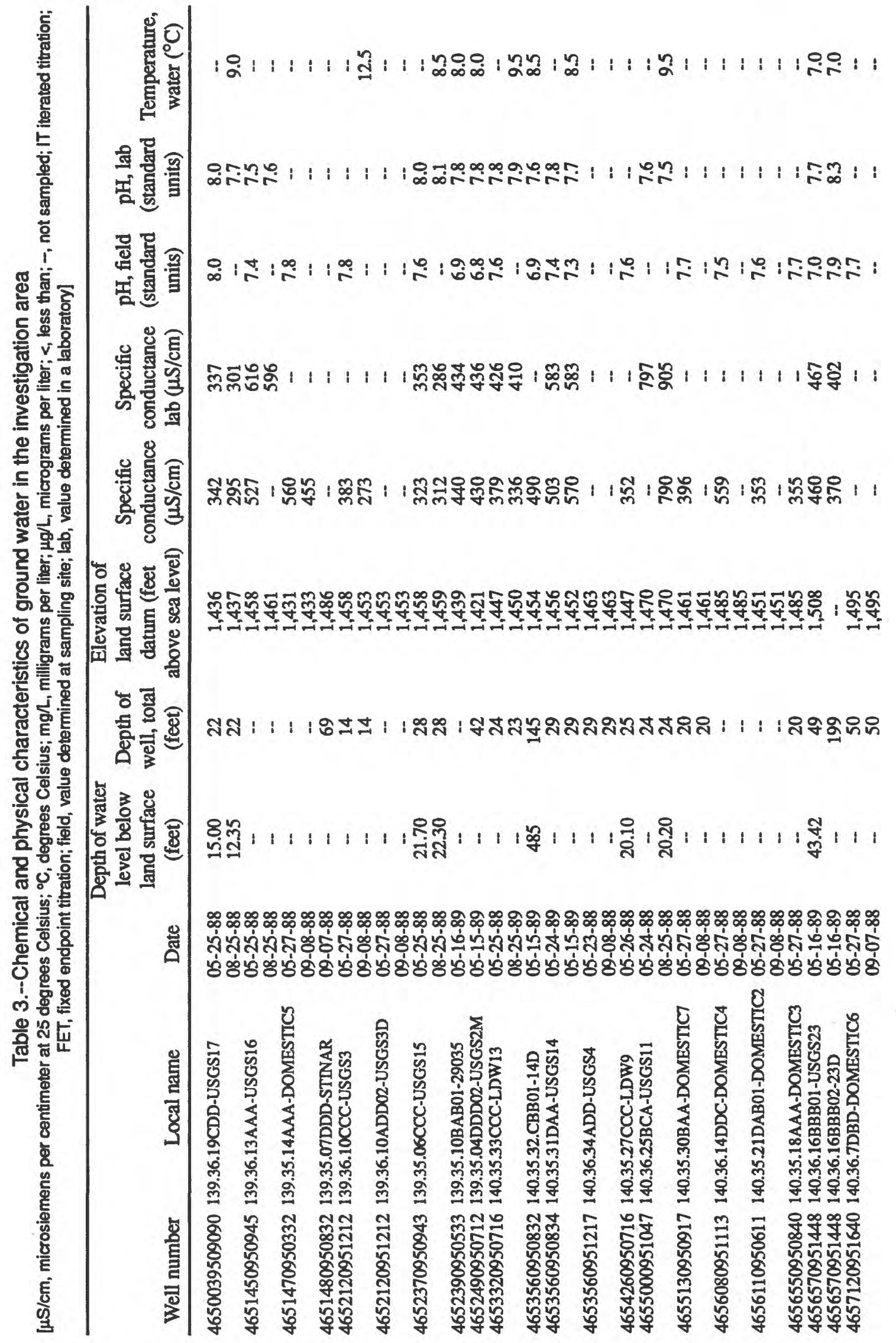




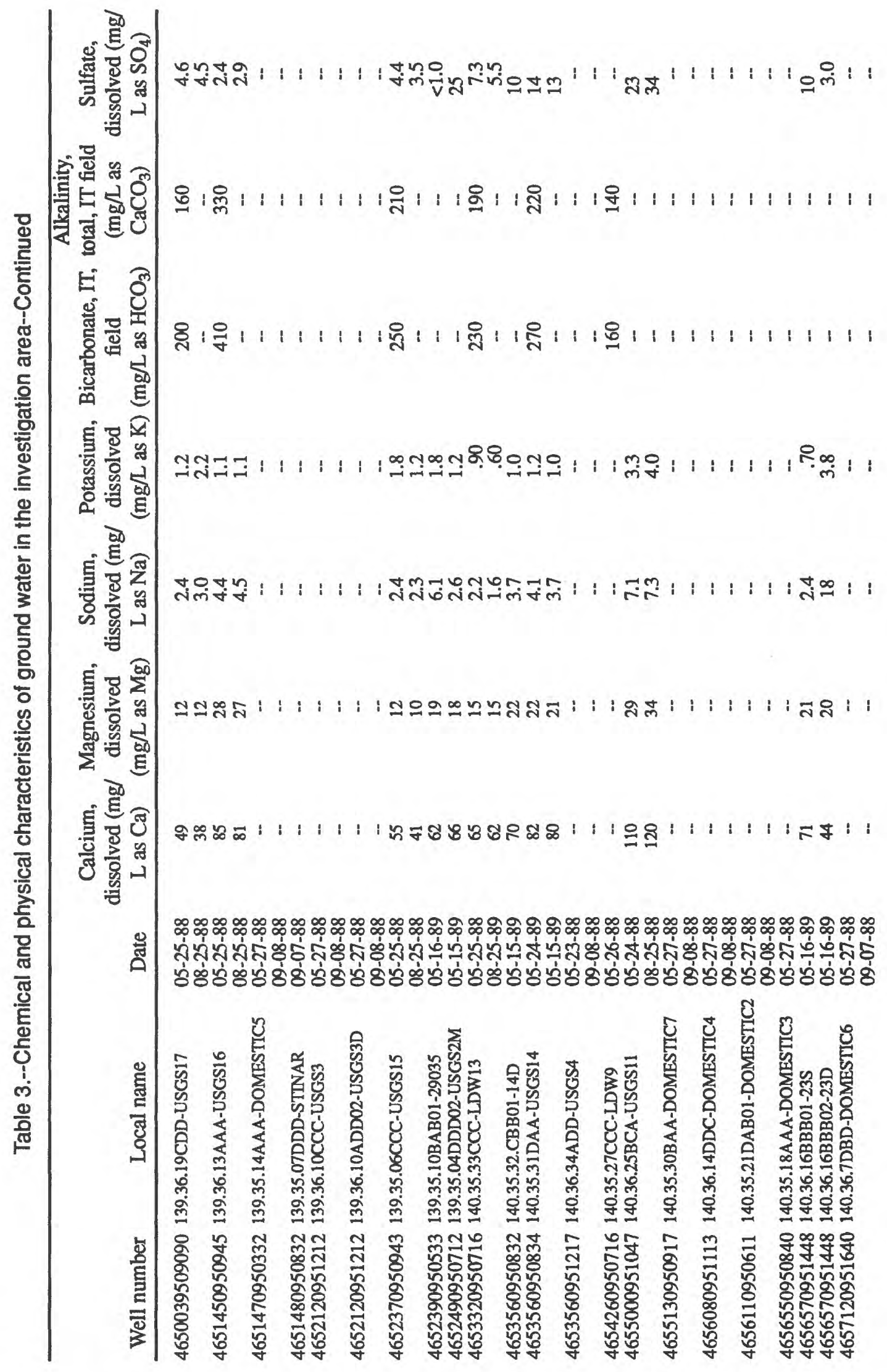




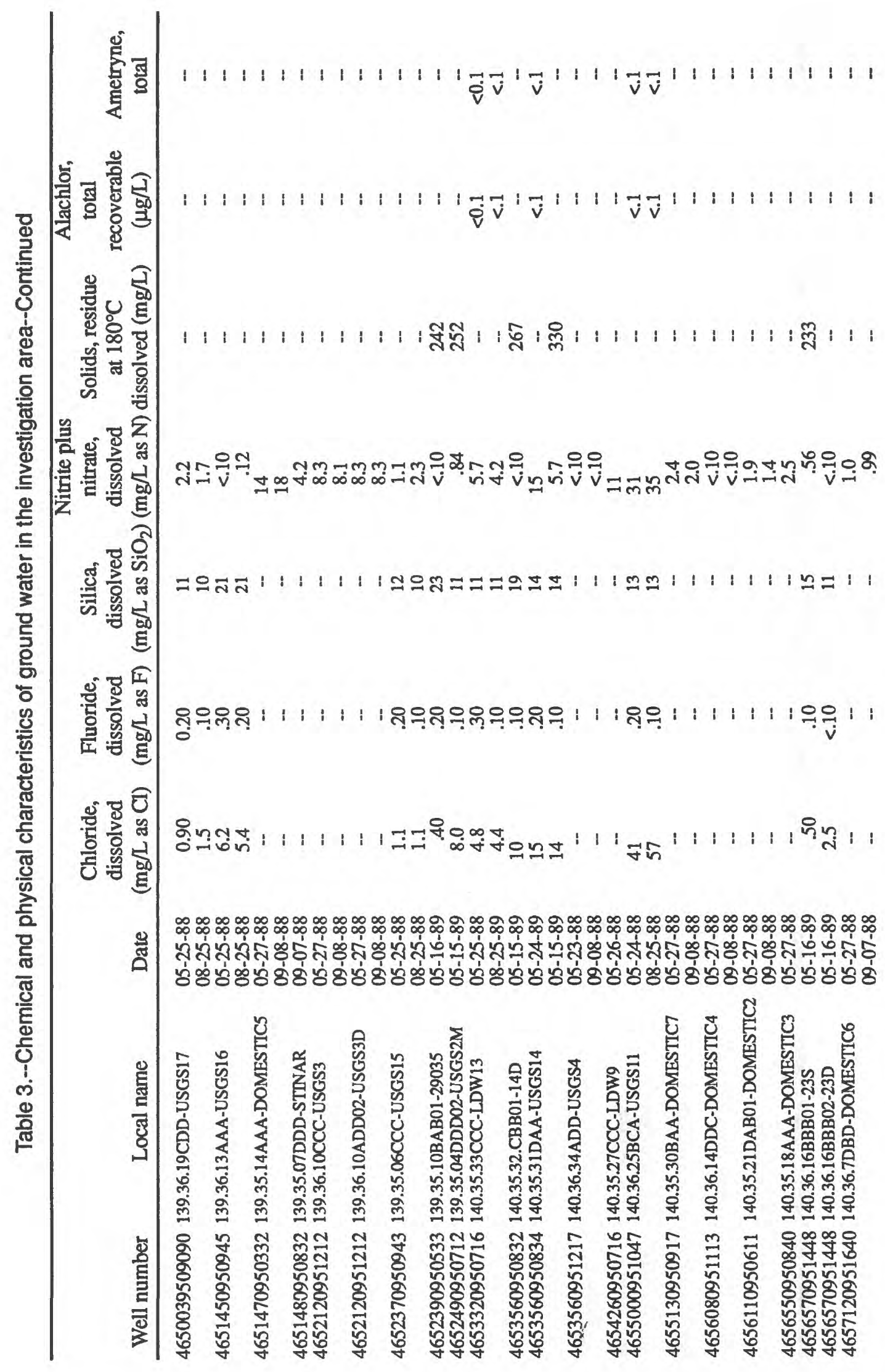




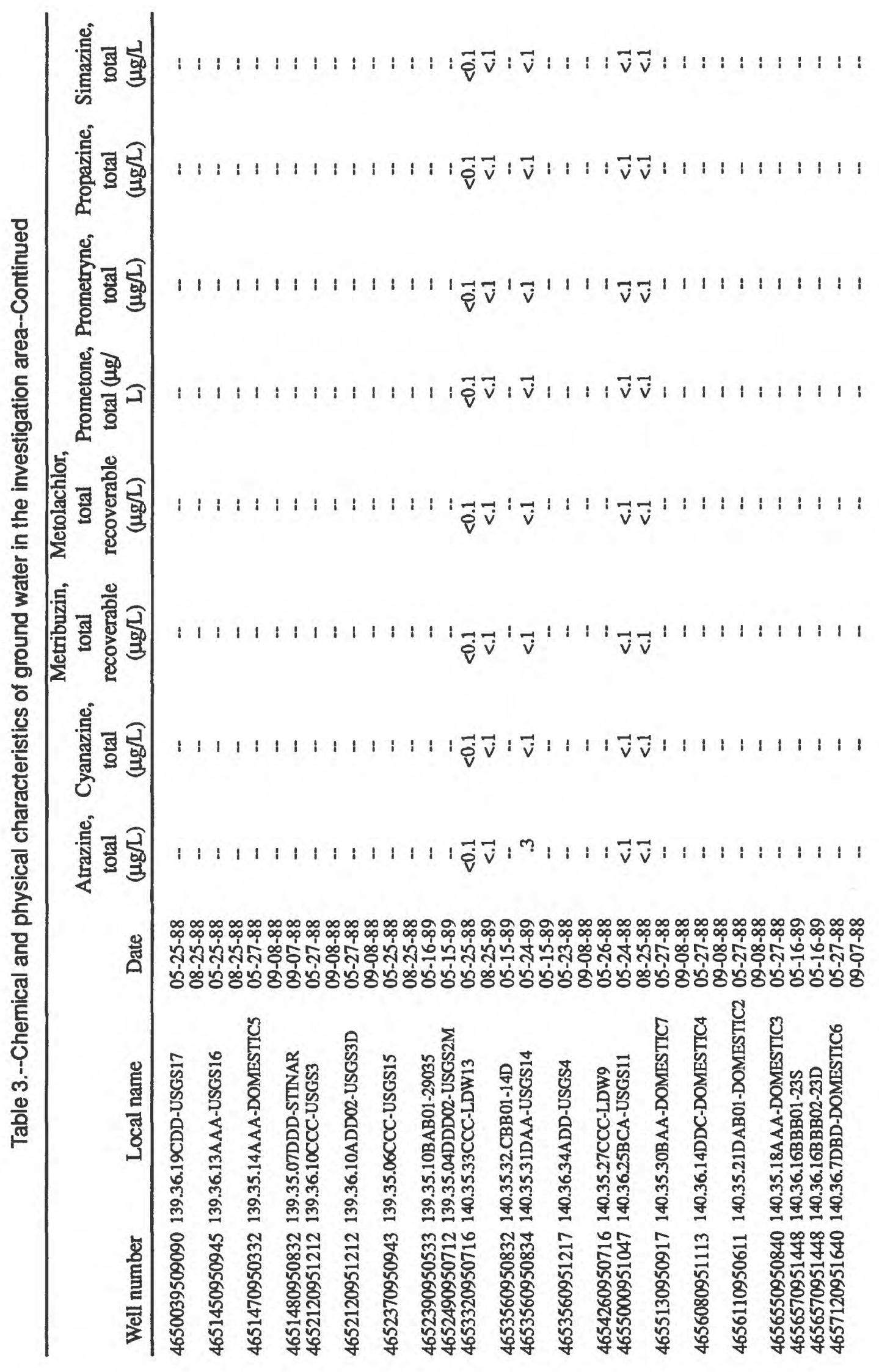




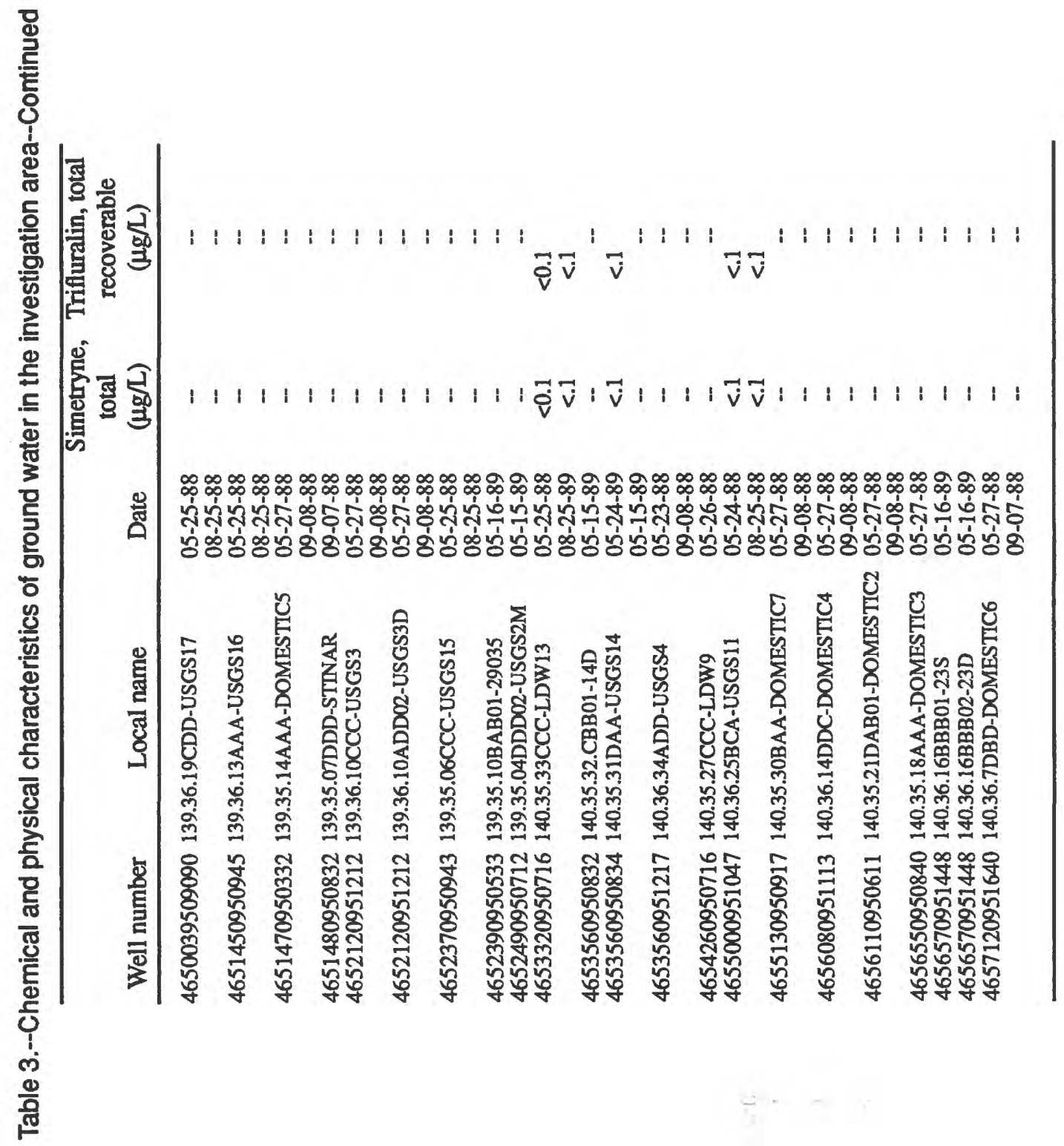




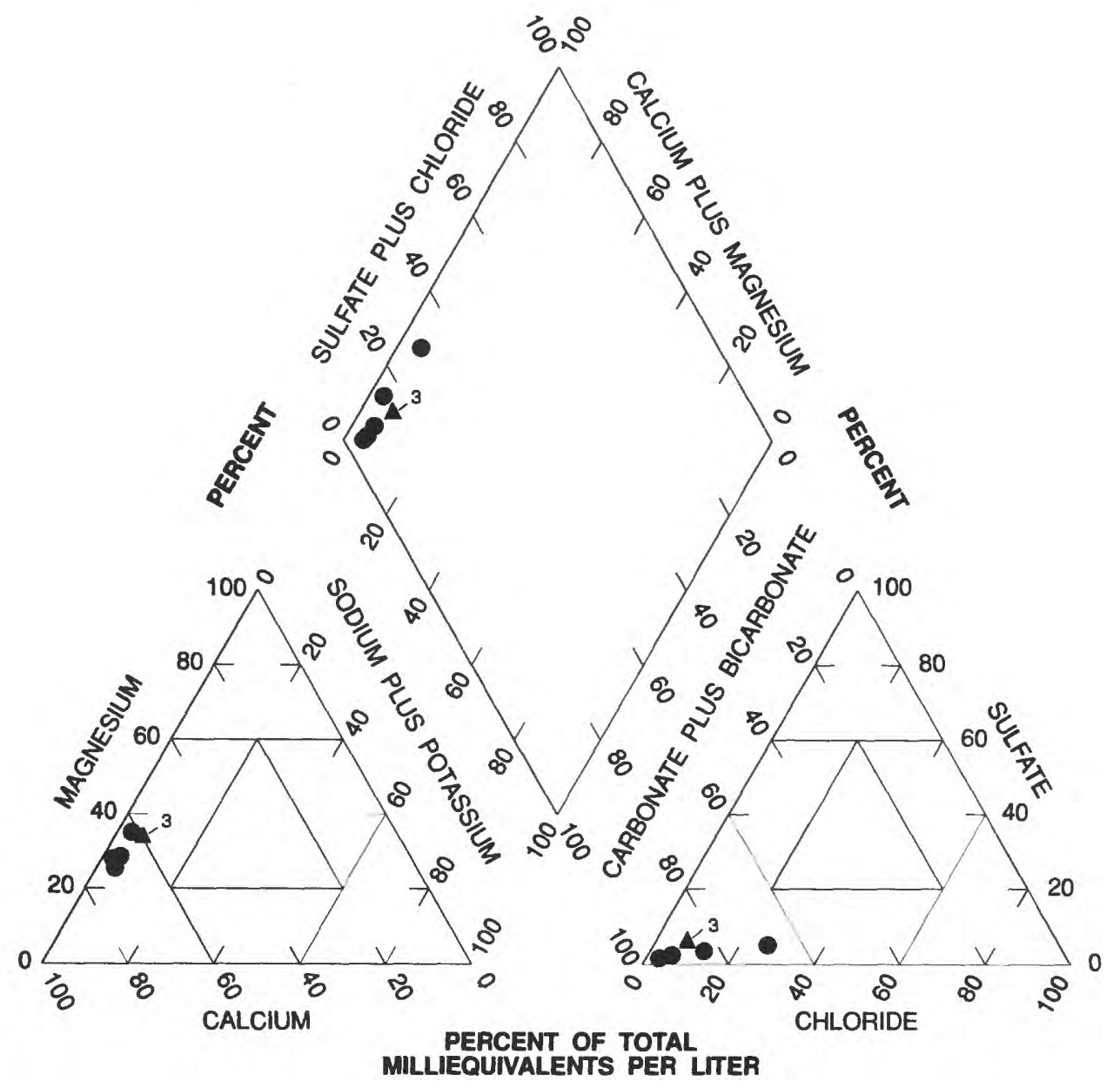

\section{EXPLANATION}

- Ground-water sample

$\boldsymbol{\varkappa}^{3}$ Stream-water sample. Number represents samples with identical percentages of total milliequivalent per liter of major ion in samples.

Figure 25.-Percentage of total milliequivalents per liter of major ions in samples collected from surficial and uppermost confined-drift aquifers and from Straight River during 1988. 
Table 4.--State-recommended limits for domestic consumption and agricultural and wildlife use for selected constituents in ground water, and percentages of wells sampled in the investigation area where water exceeds limits

[mg/L, milligrams per liter; $\mu \mathrm{g} / \mathrm{L}$, micrograms per liter; $\mu \mathrm{S} / \mathrm{cm}$, microsiemens per centimeter at 25 degrees Celsius] Recommended limits from Minnesota Pollution Control Agency and Minnesota Department of Health and Minnesota Department of Agriculture (1988).

\begin{tabular}{lcccccc}
\hline \multicolumn{1}{c}{ Constituent } & \multicolumn{2}{c}{ Concentration } & Limit type & $\begin{array}{c}\text { Number of } \\
\text { wells sampled }\end{array}$ & $\begin{array}{c}\text { Percent of wells } \\
\text { exceeding limits }\end{array}$ \\
\hline Sulfate & 250.0 & $\mathrm{mg} / \mathrm{L}$ & domestic consumption & 11 & 0 \\
Chloride & 250.0 & $\mathrm{mg} / \mathrm{L}$ & domestic consumption & 11 & 0 \\
Nitrate (nitrate plus nitrite as $\mathrm{N})$ & 10.0 & $\mathrm{mg} / \mathrm{L}$ & domestic consumption & 22 & 18 \\
Specific conductance & \multicolumn{7}{c}{ Other } & Constituent & & \\
pH & 1,000 & $\mu \mathrm{S} / \mathrm{cm}$ & Agriculture, wildlife & 17 & 0 \\
Dissolved solids & $6.0-8.5$ & $\mathrm{standard}$ units & Agriculture, wildlife & 18 & 0 \\
Alachlor & 700 & $\mu \mathrm{g} / \mathrm{L}$ & Agriculture, wildlife & 3 & 0 \\
Atrazine & 6.0 & $\mu \mathrm{g} / \mathrm{L}$ & domestic consumption & 3 & 0 \\
Cyanazine & 3.0 & $\mu \mathrm{g} / \mathrm{L}$ & domestic consumption & 3 & 0 \\
Metolachlor & 9.0 & $\mu \mathrm{g} / \mathrm{L}$ & domestic consumption & 3 & 0 \\
Metribuzin & 10.0 & $\mu \mathrm{g} / \mathrm{L}$ & domestic consumption & 3 & 0 \\
Simazine & 175.0 & $\mu \mathrm{g} / \mathrm{L}$ & domestic consumption & 3 & 0 \\
Trifluralin & 35.0 & $\mu \mathrm{g} / \mathrm{L}$ & domestic consumption & 3 & 0 \\
\hline & 2.0 & $\mu \mathrm{g} / \mathrm{L}$ & domestic consumption & 3 & 0 \\
\hline
\end{tabular}

feet deeper at the irrigated site than at the nonirrigated site.

\section{Residence Time of Ground Water}

Residence time of ground water is the time that water has been in a ground-water-flow system since infiltration from precipitation. Residence times of ground water can range from a few days to thousands of years. Groundwater-flow systems developed in deep aquifers, and systems where water flows for long distances, generally have long residence times. Ground-water-flow systems developed in shallow aquifers with local-flow systems generally have short residence times. Ground-water flow can cause mixing of water from different sources, which can in turn result in inaccurate dating of water within the aquifer.

Knowledge of residence time of ground water is important to understand the effects of land use on water quality. Isotopic analysis using carbon $14\left({ }^{14} \mathrm{C}\right.$-- an isotope of carbon) and tritium ( ${ }^{3} \mathrm{H}-$ - an isotope of hydrogen) can be used to estimate ground-water residence time. Both ${ }^{14} \mathrm{C}$ and tritium are radioactive isotopes. Prior to and after above-ground thermonuclear testing, ${ }^{14} \mathrm{C}$ in the atmosphere was derived from natural atmospheric processes involving interactions between nitrogen and cosmic rays, and was in a steady state of dynamic equilibrium. Steady-state concentrations of ${ }^{14} \mathrm{C}$ in the atmosphere resulted in a constant source of ${ }^{14} \mathrm{C}$ to ground water from precipitation infiltrating into the ground.
The law of radioactive decay describes the rate at which the activity of ${ }^{14} \mathrm{C}$ and all other radioactive substances decrease with time. Thus, the ${ }^{14} \mathrm{C}$ content of ground water can be used as a guide for ground-water residence time. Because ${ }^{14} \mathrm{C}$ has a relatively long half life (5,730 years), it can be used to estimate the residence times for ground water that infiltrated as long as 30,000 to 40,000 years before the present.

The presence of tritium in ground water is the result of both human and natural causes. Tritium is produced in the earth's atmosphere by interactions of cosmic rayproduced neutrons and nitrogen. These naturallyproduced sources of tritium result in low, but steady-state concentrations of tritium in ground water (generally less than 1 tritium unit). A tritium unit (TU) is the equivalent of one tritium atom in $10^{18}$ atoms of hydrogen. Large quantities of tritium were introduced into the atmosphere as the result of atmospheric testing of thermonuclear bombs during the 1950's and early 1960's (Freeze and Cherry, 1979). Because of the relatively short half-life of tritium (12.3 years), and the large amount of tritiated water that entered the hydrologic cycle during the 1950's and 1960 's, trituim can be used as a sensitive indicator of water that has entered ground water since 1954.

A basic difference between tritium and ${ }^{14} \mathrm{C}$ is that tritium is part of water molecules, whereas ${ }^{14} \mathrm{C}$ is in dissolved constituents in water. The potential exchange between dissolved carbon and carbon contained in sediments in aquifers in the investigation area could influence residence time calculations. 


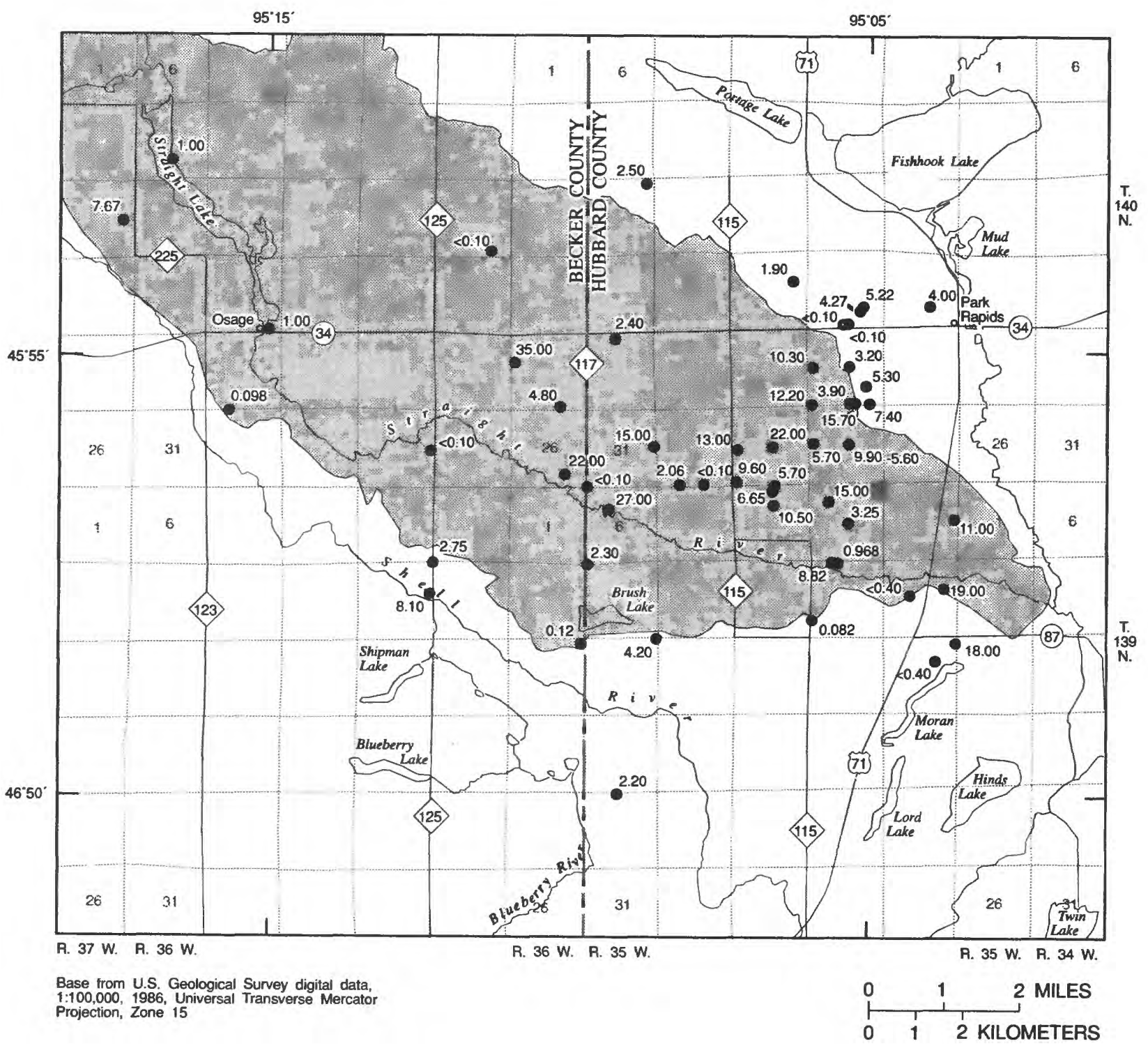

EXPLANATION

Straight River Basin

3.93 Observation well--Number shows nitrate (nitrate plus nitrite as $\mathrm{N}$ ) concentration (in milligrams per liter) in water from wells.

Figure 26.--Nitrate concentrations in ground water. 


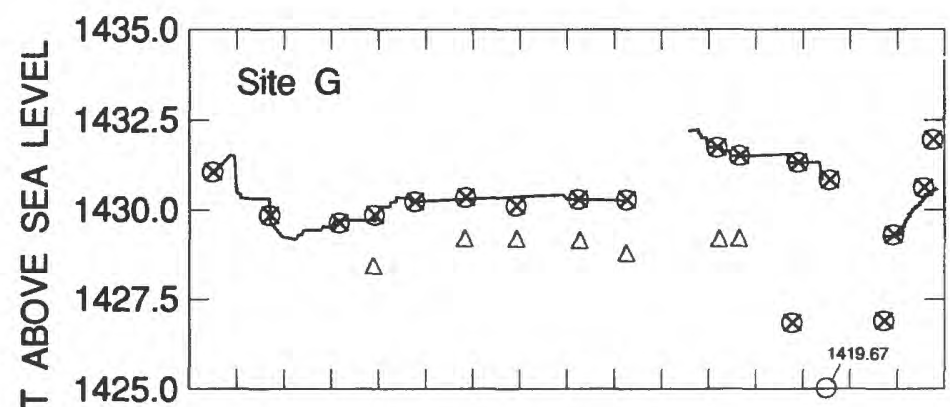

\section{EXPLANATION}

는

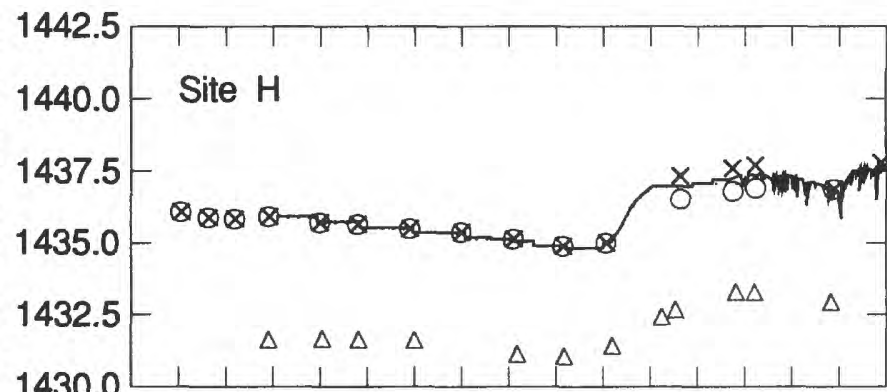

Temperature or water level measured with continuous recorder from well screened near water table.

Temperature or water level measured with continuous recorder from well screened near bottom of surficial aquifer

$\times \quad$ Temperature or water level measured with continuous recorder from well screened near water table.
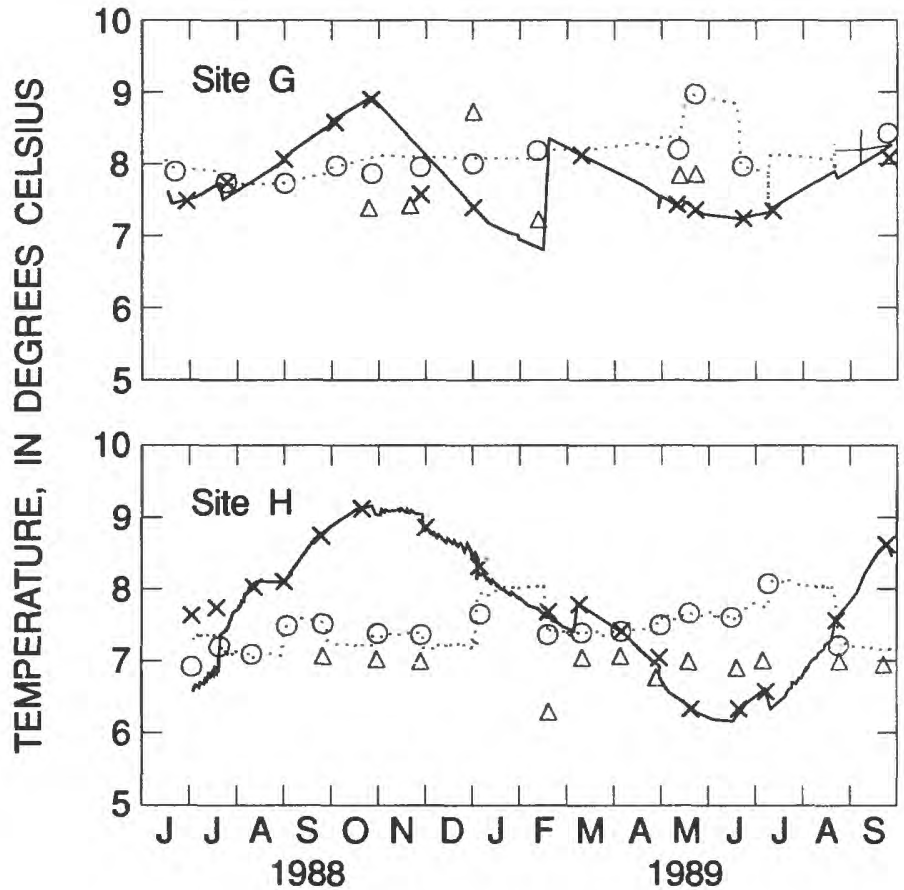

$\Delta \quad$ Temperature or water level measured in well screened in uppermost confineddrift aquifer.

Figure 27.--Temperatures and water levels in surficial and uppermost confined-drift aquifers at irrigated (site $\mathbf{G}$ ) and nonirrigated (site $\mathbf{H}$ ) areas in investigation area.

A classification to describe the residence time of ground water based on the concentrations of ${ }^{14} \mathrm{C}$ and tritium in ground water has been developed by Calvin Alexander (University of Minnesota, written commun., 1990). Water with concentrations of ${ }^{14} \mathrm{C}$ of at least 50 percent of current precipitation and tritium concentrations greater than $10 \mathrm{TU}$ are termed recent water. These waters are dominated by water that entered the ground since 1954. Vintage water is defined as that containing concentrations of ${ }^{14} \mathrm{C}$ less than 50 percent of the concentration of modern precipitation and tritium less than one TU. These waters are dominated by water that entered the ground before the advent of atmospheric testing of nuclear weapons in 1954. Mixed water contains water with ${ }^{14} \mathrm{C}$ greater than 50 percent of the concentration of modern precipitation and tritium 
between 1 and $10 \mathrm{TU}$. The average residence time of these mixed waters probably ranges from about 40 to a few-hundred years. Ancient waters contain concentrations of ${ }^{14} \mathrm{C}$ less than 50 percent of modern and no detectable tritium (less than 1 TU).

Water from 19 wells was collected and analyzed for ${ }^{14} \mathrm{C}$ and tritium. Results of the analyses of water from wells screened in the surficial aquifer showed that waters from that aquifer were isotopically recent, regardless of the depth of the well. Tritium concentrations generally were greater that $50 \mathrm{TU}$. The uppermost confined-drift aquifer contains waters that are recent, vintage, and mixed. Increased tritium in the uppermost confined-drift aquifer was in areas of significant irrigation ground-water withdrawal, indicating that ground-water withdrawal may be inducing downward leakage of isotopically younger waters from the surficial aquifers. Waters from the deeper confined-drift aquifers generally have tritium concentrations of less than one TU and, based on ${ }^{14} \mathrm{C}$ data, are about 12,000 years old. Residence-time data are significant because they indicate that waters in both the surficial and in the uppermost confined-drift aquifers are susceptible to contamination from local recharge.

\section{Stream-Aquifer Interactions}

A dynamic set of hydrologic conditions cause water to move through aquifers and confining units (fig. 2) in the Straight River watershed, resulting in discharge to the Straight River. The direction and rate of water movement from the aquifers to the Straight River is affected by (1) aquifer recharge, (2) hydraulic conductivity, (3) hydraulic gradient, (4) hydraulic conductivity of the streambed and, (5) the hydraulic head difference between the stream and aquifer. Recharge to the surficial aquifer occurs everywhere the aquifer is present. Ground-water discharges into the stream along most of the length of the stream because the hydraulic head in the surficial aquifer is greater than the hydraulic head of the stream. Part of the water flows through the surficial aquifer and part flows through surficial aquifer, confining units, and the uppermost confined-drift aquifer before being discharged to the stream.

Comparison of the potentiometric surfaces of the surficial and the uppermost confined-drift aquifers (figs. 15 and 22) shows that the two surfaces have similar configurations. The differences in hydraulic head between the aquifers also indicate that downward leakage occurs in highland areas where ground water flows vertically downward to the uppermost confined-drift aquifer. In areas of discharge (near streams), water moves vertically upward from the uppermost confined-drift aquifer to the surficial aquifer and then to the stream.
Ground water flows into the Straight River Basin in the southwestern part of the investigation area, near the Shell River, where the ground-water basin does not coincide with the surface-water basin. Ground-water flow in this area is from the southwest. Hydraulic gradients indicate that flow from areas outside the Straight River Basin is significant and contributes to the relatively high base flow of the stream compared to streams with similar surfacebasin areas.

Results of the hydrograph analysis (tab. 5) indicate that at least 95 percent of streamflow in the Straight River during the 1988 water year was derived from base flow. Using a technique developed by Wahl and Wahl (1988), which is based on a method proposed by the Institute of Hydrology (1980a, 1980b), the data also show that incremental base-flow decreases slightly in a downstream direction.

Base-flow gain measured between gaging stations allows for analysis of the spatial variability of base flow within the watershed. Because the area upstream from site $B$ is more than half of the watershed area, the change in base flow per square mile supplying the sites downstream from site $B$ is masked by the magnitude of area and flow upstream of site B and by the effect of Straight Lake. Incremental base flow, which represents base flow contributing only to the areas between sites, is $0.835 \mathrm{ft} / \mathrm{yr}$ (feet per year) for the area between sites B and $D$, and $0.759 \mathrm{ft} / \mathrm{yr}$ for the area between sites $D$ and F. These values are expressed as depth of water over the contributing area.

Recharge commonly occurs during the spring from snowmelt and rain. Recharge also may occur during autumn. Rates of ground-water recharge usually are low in the summer and winter because most precipitation is lost to evapotranspiration or is held as snowpack. Streambase-flow data indicate that a recharge rate of greater that $12 \mathrm{in}$./yr (inches per year) is typical for the surficial aquifer in the Straight River watershed. This rate is significantly greater than most estimates of recharge to sand plain areas in Minnesota, and is twice as great as mean annual runoff for the general area (Jacques and Lorenz, 1988). The rate is also significantly greater than the average value of ground-water recharge (5.1 in./yr) reported by Helgesen (1977) for the Pineland Sands.

Recharge, estimated from base flow in the Straight River, may be larger than estimates of recharge to sand plain aquifers from other studies in Minnesota because of highly permeable surficial deposits, because of the contribution of underflow into the watershed, or because of a combination of these factors. This rate of recharge is one explanation for the sustained high base flow in the stream. 


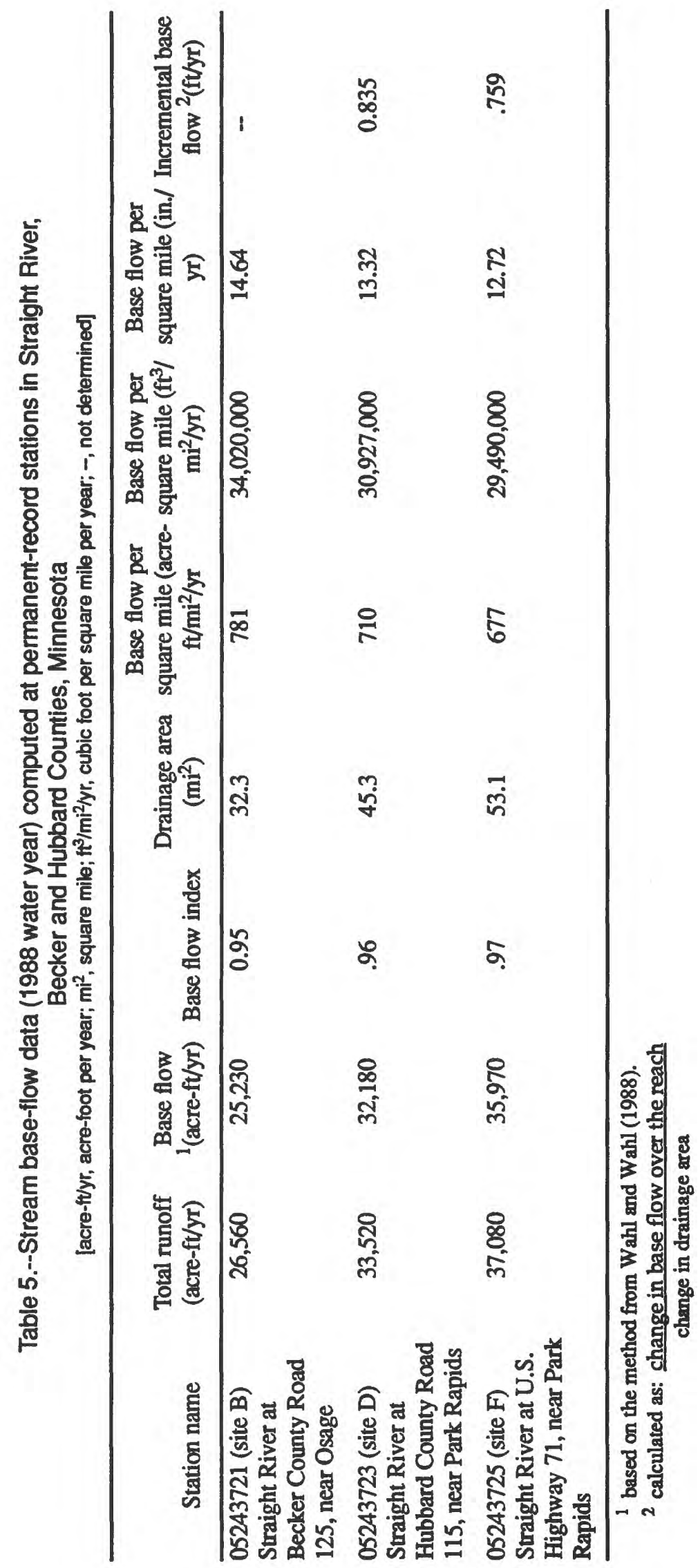


Ground water leaves the aquifer system by evapotranspiration, by withdrawals through wells, and as discharge to the Straight River, ponds, and wetlands. A significant portion of discharge from the ground-water system is to the Straight River and to production wells. The Straight River is the major discharge zone for the uppermost confined-drift and surficial aquifers; the aquifers are the primary source of water to the stream. Ground-water divides, which separate ground-waterflow systems discharging to the Straight River from systems that discharge to the other streams, are approximately coincidental with the surface-water divides between the streams. An exception is in the vicinity of the Shell River in the southwestern part of the investigation area where there is underflow into the Straight River watershed from the southwest. The direction of ground-water flow varies near many wetlands and ponds.

The amount of ground-water loss to evapotranspiration depends on water availability (particularly depth to the water table below land surface), solar energy supplied, air temperature, and humidity. The rate of evapotranspiration is assumed to be a maximum of 22 in./yr (Baker and others, 1979) where water levels are at land surface. This rate is assumed to decrease to zero where water levels are below the root-zone depth. The approximate root-zone depth for vegetation in the investigation area is assumed to be about $5 \mathrm{ft}$. Large quantities of water are discharged from the ground-water system through evapotranspiration during the summer. These losses decrease rapidly in the fall and are near zero in the winter.

Ground-water withdrawals to 53 high-capacity irrigation wells were a major use of ground water in the investigation area in 1988. Withdrawal from these wells was divided between the surficial aquifer ( 23 wells) and the uppermost confined-drift aquifer ( 25 wells) at that time. The average irrigated field received about $12 \mathrm{in}$. of irrigation water in 1988. During 1988 approximately 2.3 billion gallons of ground water were withdrawn from the aquifers beneath the drainage basin. This consisted of 0.9 billion gallons from the surficial aquifer, and 1.4 billion gallons from the uppermost confined-drift aquifer. The total compares with a total stream discharge of the Straight River at U.S. Highway 71 of 3.7 billion gallons during the four-month (May-August) summer period.

In general, ground-water discharge to the Straight River exceeds leakage from the river into the groundwater system. An exception may occur during periods of heavy ground-water withdrawal, when water from the river enters the aquifer along short reaches of the river.
Measurements of ground-water discharge to lakes and to swamps were not made during this investigation.

Streamflow in the Straight River during September 1987-September 1988 ranged from about $25 \mathrm{ft}^{3} / \mathrm{s}$ near the outlet of Straight Lake near Osage to about $51 \mathrm{ft}^{3} / \mathrm{sat}$ U.S. Highway 71, near the mouth. Streamflow, which was relatively uniform throughout the year, increased in a downstream direction during most of the year. As described previously in the section on low flow characteristics, base flow increased by an average of 14.5 $\mathrm{ft}^{3} / \mathrm{s}$ between sites $\mathrm{B}$ and $\mathrm{F}$ during the 1988 water year. Between sites B and D base flow increased by about 9.6 $\mathrm{ft}^{3} / \mathrm{s}$, between sites $D$ and $F$, it increased by about $4.9 \mathrm{ft}^{3} / \mathrm{s}$ (tab. 5). During periods of low flow, the gain between sites $\mathrm{D}$ and $\mathrm{F}$ was a smaller percentage of the total base flow (Gunard and others, 1990). These data indicate that there were times, during periods of low flow, when the lower reaches of the Straight River lost water to the surficial aquifer. These losses may have been due to ground-water withdrawal or to increased evapotranspiration from wetlands near the stream in the lower reaches of the watershed. As a percentage of total flow in the stream, however, these losses were small. Analysis of discharge in the Straight River is complicated by backwater from ice in the winter and by aquatic vegetation in the channel during the summer. These conditions affect the collection of accurate streamdischarge data.

The runoff and base-flow components upstream from each of the permanent-record stations on the Straight River were calculated for the 1988 water year using a technique developed by Wahl and Wahl (1988), which is based on a method proposed by the Institute of Hydrology (1980a, 1980b). It involves dividing the year into 5-day increments and identifying the minimum flow for each increment. When a value of 0.9 times this minimum is less than the preceding and following minima, the minimum is considered a turning point of the base-flow hydrograph. The area beneath a line drawn between turning points is used as an estimate of the volume of base flow for the period. The ratio of this volume to the actual volume of discharge for the period is defined as the baseflow index. Although the method does not exactly duplicate the values of base flow obtained from other methods, tests in Great Britain (Institute of Hydrology, 1980b; Swan and Condie, 1983) indicate results that are similar to that of other methods.

Stream discharge data (tab. 5) show that average base flow in the watershed (expressed as depth over the watershed) during the 1988 water year (a period of drought) was greater than one foot. This value is significantly greater than most estimates of ground-water 

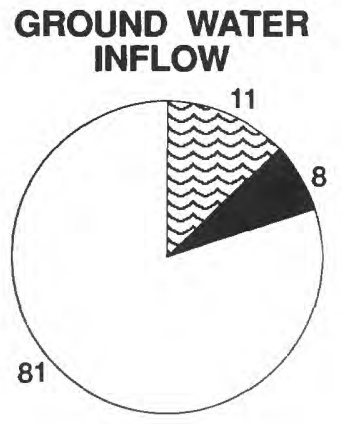

Pre-pumping conditions
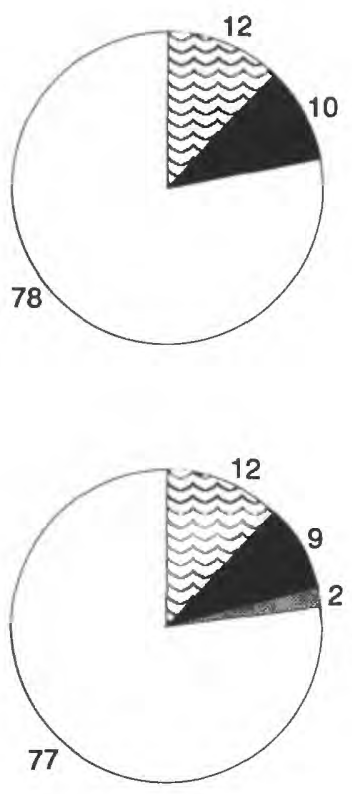

1988 pumping conditions

Twice 1988 pumping conditions

\section{EXPLANATION}

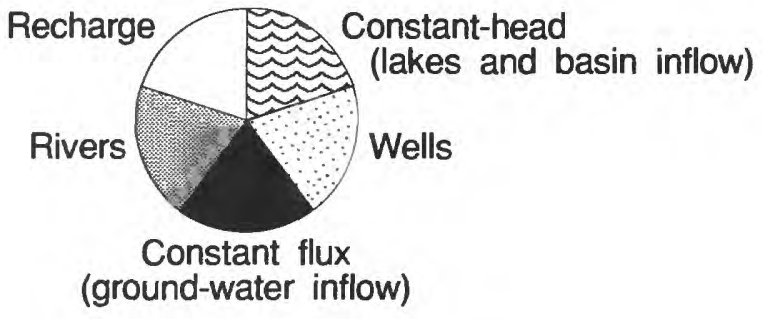

All values in percent

Figure 28.-Model-calculated, ground-water inflow and outflow for simulations representing pre-development, 1988, and hypothetical (doubling of 1988 ground-water withdrawal) rates of ground-water withdrawal from the investigation area. 
recharge to sand plains in Minnesota. Helgesen (1977), estimated ground-water recharge in the Pineland Sands area at about $5.1 \mathrm{in} . / \mathrm{yr}$. Recharge to the ground-water system in this area may be increased because of highlypermeable surficial deposits.

Results of model simulations (fig. 28) conducted for this investigation indicate that ground-water withdrawal rates similar to those of $\mathbf{1 9 8 8}$ have the potential to reduce streamflow gain by as much as 34 percent during the irrigation season.

Ground-water inflow temperature, which averages about $7^{\circ} \mathrm{C}$ throughout the year, helps to keep the Straight River cool during summer. Model simulations were conducted to evaluate the potential effect of reduced ground-water inflow on stream temperature. Reduced ground-water inflow was simulated to have resulted from ground-water withdrawal for irrigation. In these simulations, model-input conditions were identical to conditions for simulations used to calibrate the model to measured stream conditions except that ground-water inflow was reduced by 34 percent. Results of the simluations indicate that a potential reduction in streamflow due to irrigation has potential to cause an increase in stream temperature of 0.5 to $1.5^{\circ} \mathrm{C}$. This potential increase may have an adverse effect on the habitat of the stream for trout. There currently is little evidence to indicate, however, that irrigation is having a significant effect on ground-water temperature, or on the temperature of the Straight River.

The construction of the dam at Osage also may have resulted in increased temperature of the Straight River. Measurements of water temperature in Straight Lake indicate that itranges from about $22^{\circ} \mathrm{C}$ near the surface to about $10^{\circ} \mathrm{C}$ at depths of 45 feet below the lake surface during late summer. Relatively warm surface and nearsurface lake water flows into the stream below the dam. Model simulations of the stream, in which the temperature of water discharging from the lake was reduced by $5^{\circ} \mathrm{C}$, were conducted to represent possible bottom release of water from the dam. These simulations indicate that stream temperature could be reduced by as much as $1.3^{\circ} \mathrm{C}$, about three miles downstream from the dam at site $B$, if the outlet structure of the dam were changed. The reduction in stream temperature was found to be less significant downstream from site $B$.

Ground water and stream water in the area generally are of the calcium bicarbonate type, and nearly identical in composition. The chemistries of water from the surficial and the uppermost confined-drift aquifers, and from the Straight River, generally are similar. Figure 25 illustrates that common cations and anions plot in the same general areas of the diagram for both aquifers and the stream. The similar grouping of data shows that major cations and anions in water samples from the surficial and uppermost confined-drift aquifers have concentrations which indicate that most stream water originates as ground water.

Figures 10 and 11 illustrate the temperature of the stream, air, and ground water in detail during July 1988 (sites A and B) and January 1989 (sites A nd F). At site A during July, (fig. 11) just downstream from the dam at the outlet of Straight Lake, stream temperature is relatively constant due to discharge of water from the lake, and averages about $25^{\circ} \mathrm{C}$. The stream is not significantly influenced by fluctuations in air temperature at this site. At site B (downstream) stream temperature has significant daily fluctuations, and is primarily related to air temperature. Stream temperature at site B is colder than at site $A$ because of an increase in ground-water inflow, and averages about $19^{\circ} \mathrm{C}$ during July.

Figure 10 illustrates the thermal characteristics of the stream at the sites A and F during January. Stream temperatures approach $0^{\circ} \mathrm{C}$, but water generally does not freeze because of turbulence, the thermal heat of fusion, and the influence of warmer ground water flowing into the stream. Winter stream temperature is slightly warmer at site $A$ than at site $F$ because of continuous release of warmer water stored in Straight Lake and from ground water. Daily fluctuations of water temperature in the river are not significantly influenced by air temperature in the winter.

Water at site B generally is colder during the summer than at other sites because this is an area of ground-water inflow along the stream. Ground-water inflow temperature, which averages about $7^{\circ} \mathrm{C}$ throughout the year except in areas where the water table is near land surface, tends to reduce stream temperature during the summer and increase stream temperature during winter.

\section{Effects of Irrigation}

Stream discharge data indicate that the Straight River was affected by irrigation pumping during the summer of 1988. Model simulations, described in the Ground-Water Flow Model section of the Supplemental Information Section, were evaluated by matching model-calculated streamflow and ground-water-level information with measured data from the summer of 1988. A lack of longterm data on ground-water withdrawal for irrigation, ground-water recharge, and water level does not allow the time-dependent (transient) simulation of the groundwater system. During the summer, the water-table and potentiometric surface of the uppermost confined-drift aquifer approached low levels. These water levels are assumed to be near steady-state conditions where sources 
of water approximated sources of discharge, and little change in storage occurred. These simulations indicate that continuous irrigation at rates comparable to those of 1988 , and given ground-water recharge similar to that of 1988 , could result in water-level declines ranging from 0 to $10 \mathrm{ft}$ in the surficial aquifer and 0 to $15 \mathrm{ft}$ in the uppermost confined-drift aquifer. This lowering of the water table and the potentiometric surface could result in a reduction of stream base flow of about 34 percent compared to conditions of no ground-water withdrawal for irrigation (fig. 28).

\section{Summary and Conclusions}

The Straight River contains water that is coldand clear. The $75 \mathrm{mi}^{2}$ Straight River watershed is underlain by highly transmissive surficial and confined-drift aquifers. Ground-water withdrawals from these aquifers, which sustain flow of the Straight River, are increasing in response to changes in land use from dry-land farming to irrigated farming. A decrease in ground-water discharge to the stream caused by withdrawals for irrigation has potential to increase stream temperature, which would in turn affect the trout habitat in the stream.

Data indicate a hydraulic connection between the stream and the surficial aquifer. Discharge of the Straight River increased from about $25 \mathrm{ft}^{3} / \mathrm{s}$ near the outlet of Straight Lake to about $51 \mathrm{ft}^{3} / \mathrm{s}$ near the mouth. The rate of gain in discharge during summer decreased downstream, possibly as a result of ground-water withdrawal for irrigation. Hydraulic conductivity values for the surficial and uppermost confined-drift aquifers average about 255 and $300 \mathrm{ft} / \mathrm{d}$, respectively, based on results of previous studies and model simulations. The water table in the surficial aquifer and potentiometric surface of the uppermost confined-drift aquifer slope toward the Straight River at a gradient of about $10 \mathrm{ft} / \mathrm{mi}$.

Daily fluctuations of stream temperature are as great as $15^{\circ} \mathrm{C}$ during the summer. Ground-water discharge cools the stream during the summer and warms it in the winter. Results of stream-temperature model simulations indicate that daily changes in stream temperature are strongly influenced by solar radiation, wind speed, stream depth, and ground-water inflow. Nitrate concentrations in water from shallow wells completed at the water table are greater, at least locally, than the limit set by the MPCA. Nitrate concentrations in water from deeper wells and in the stream generally are less than $1.0 \mathrm{mg} / \mathrm{L}$.

Results of simulations made using ground-water-flow and stream-temperature models developed for the study indicate that a significant decrease in ground-water flow may result from ground-water withdrawal at rates similar to those in 1988, and that this reduction in discharge to the stream may result in an increase in stream temperature of as much as 0.5 to $1.5^{\circ} \mathrm{C}$.

\section{Selected References}

Alexander, Scott C. and Alexander, E. Calvin, Jr., 1989, Residence times of Minnesota groundwaters: Journal of Minnesota Academy of Sciences, v. 55, p. 48-52.

Allison, I.S., 1932, The geology and water resources of northwestern Minnesota: Minnesota Geology Survey Bulletin 22, $245 \mathrm{p}$.

Baker, D.G. and Kuenhast, E.A., 1978, Climate of Minnesota Part X, Precipitation normals for 19411970: Minnesota Agricultural Experimentation Station Technical Bulletin 314, 15 p.

Baker, D.G., Nelson, W.W., and Kuehnast, E.A., 1979, Climate of Minnesota Part XII, The hydrologic cycle and soil and water: Minnesota Agricultural Experimentation Station Technical Bulletin 322, $23 \mathrm{p}$.

Barker, R.A., Dunlap, L.E., and Sauer, C.G., 1983, Analysis and computer simulation of streamaquifer hydrology, Arkansas River Valley, southeastern Kansas: U.S. Geological Survey Water-Supply Paper 2200, 59 p.

Burnett, R.D., and Reed, T.B., 1986, Availability of water for irrigation in the South Fork Solomon River Valley, Webster Reservoir to Waconda Lake, North-Central Kansas: U.S. Geological Survey Water Resources Investigations Report 86-4064, $89 \mathrm{p}$.

Burns, Alan W., 1985, Hydrologic description of the Tamarack Wildlife area and vicinity, Logan County, Colorado, and simulated effects of possible water-management activities: U.S. Geological Survey Water- Resources Investigations Report 85-4014, 42 p.

Delin, G.N., 1986, Hydrogeology of confined-drift aquifers near the Pomme De Terre and Chippewa Rivers, Western Minnesota: U.S. Geological Survey Resources Investigation 86-4098, 90 p.

Domenico, P.A., and Palciauskas, V.V., 1973, Theoretical analysis of forced convective heat transfer in regional ground-water flow: Geological Society of America Bulletin, v.84, p. 3803-3814. 
Dunlap, L.E., Lindgren, R.J., and Carr, J.E., 1984, Projected effects of ground-water withdrawals in the Arkansas River Valley, 1980-99, Hamilton and Kearney Counties, southwestern Kansas: U.S. Geological Survey Water-Resources Investigations Report 84-4082, 168 p.

Freeze, R.A. and Cherry, J.A., 1979, Groundwater: Prentice-Hall Inc., Englewood Cliffs, New Jersey, $604 \mathrm{p}$.

Gunard, K.T., Hess, J.H., Zirbel, J.L., and Cornelius, C.E., 1990, Water resources data for Minnesota Water Year 1988, Vol. 2 Upper Mississippi and Missouri River Basins: U.S. Geological Survey Water-Data Report MN-88-2, p. 65-70.

Heath, R.C., 1983, Basic ground-water hydrology: U.S. Geological Survey Water- Supply Paper 2220, $84 \mathrm{p}$.

Helgesen, J.O., 1977, Ground-water appraisal of the Pineland Sands area, central Minnesota: U.S. Geological Survey Open-File Report 77-102, 49 p.

Hem, J.D., 1985, Study and interpretation of the chemical characteristics of natural waters: U.S. Geological Survey Water-Supply Paper 2245, 263 p.

Hobbs, H.G., and Goebel, J.E., 1982, Geologic Map of Minnesota, Quaternary Geology: Minnesota Geological Survey State Map Series S-1, 1 sheet, scale 1:500,000.

Institute of Hydrology, 1980a, Low flow studies: Wallingford, Oxon, United Kingdom, Report No. $1,21 \mathrm{p}$.

Institute of Hydrology, 1980b, Low flow studies: Wallingford, Oxon, United Kingdom, Report No. 3, p. 12-19.

Jacques, J.E., and Lorenz, D.L., 1988, Techniques for estimating the magnitude and frequency of floods in Minnesota: U.S. Geological Survey WaterResources Investigations Report 87-4170, 48 p.

Jenkins, C.T., 1968, Techniques for computing rate and volume of stream depletion by wells: Ground Water, v. 6, no. 2, 37-46 p.

Jobson, H.E., 1975, Canal evaporation by thermal modeling: Proceedings of the Symposium on Modeling Techniques, American Society of Civil Engineers, San Francisco, California, September 3-5, 1975, p. 729-744.

Jobson, H.E., 1979, Modeling highly transient flow, mass, and heat transport in the Chattahoochee River near Atlanta, Georgia: U.S. Geological Survey Professional Paper 1136, 42 p.
Jobson, H.E., 1980a, Temperature and solute-transport simulation in streamflow using a Lagrangian reference frame: U.S. Geological Survey WaterResources Investigations Report 81-2, 165 p.

Jobson, H.E., 1980b, Thermal modeling of flow in the San Diego Aqueduct, California and its relation to evapotranspiration: U.S. Geological Survey Professional Paper 1122, 24 p.

Kilpatrick, F.A., and Wilson, J.F., Jr., 1989, Measurement of time of travel in streams by dye tracing: U.S. Geological Survey Techniques of Water- Resources Investigations, Book 3, Applications of hydraulics, Chapter A9, 27 p.

Kipp, Kenneth L., Jr., 1987, HST3D: A computer code for simulation of heat and solute transport in threedimensional ground-water flow systems: U.S. Geological Survey Water-Resources Investigations Report 86-4095, 517 p.

Leverett, Frank, 1932, Quaternary geology of Minnesota and parts of adjacent states: U.S. Geological Survey Monograph 25, 658 p.

Lindholm, G.F., 1970, An appraisal of ground water for irrigation in the Wadena area, central Minnesota: U.S. Geological Survey Water-Supply Paper 1983, $56 \mathrm{p}$.

Lindholm, G.F., Oakes, E.L., Erickson, D.W., and Helgesen, J.O., 1972, Water resources of the Crow Wing River watershed, central Minnesota: U.S. Geological Survey Hydrologic Investigations Atlas HA-380.

Lohman, S.W., 1972, Ground-water hydraulics: U.S. Geological Survey Professional Paper 708, 70 p.

McDonald, M.G., and Harbaugh, A.W., 1988, A modular three-dimensional finite-difference ground-water-flow model: U.S. Geological Survey Techniques of Water Resources Investigations, Book 6, Chapter A1, 528 p.

Miller. R.T., 1982, Appraisal of the Pelican River sandplain aquifer, westem Minnesota: U.S. Geological Survey Open-File Report 82-347, 40 p.

Minnesota Department of Health and Minnesota Department of Agriculture, 1988, Pesticides and groundwater-Survey of selected Minnesota Wells: Report prepared for the Legislative Commission on Minnesota Resources, February, $1988,95 \mathrm{p}$. 
Minnesota Pollution Control Agency, 1978, Minnesota code of agency rules; Criteria for classification of interstate waters of the state and the establishment of standards of quality and purity: Minnesota Pollution Control Agency Division of Water Quality Regulation 6MCAR/4.8012 (WPC 14), $10 \mathrm{p}$.

Minnesota Pollution Control Agency, 1988, Minnesota code of agency rules; Standards for protection of the quality and purity of the waters of the State: Minnesota Pollution Control Agency Division of Water Quality Regulations, Minnesota Rules, chap. 7050, 133 p.

Minnesota Pollution Control Agency and Minnesota Department of Agriculture, 1991, Nitrogen in Minnesota ground water: Minnesota Pollution Control Agency, Draft report prepared for the Legislative Water Commission.

Myette, C.F., 1984, Ground-water-quality appraisal of sand-plain aquifers in Hubbard, Morrison, Otter Tail, and Wadena Counties, Minnesota: U.S. Geological Survey Water-Resources Investigations Report 84-4080, 49 p.

Oakes, E.L., and Bidwell, L.E., 1968, Water resources of the Upper Mississippi headwaters watershed: U.S. Geological Survey Hydrologic Investigations Atlas, HA-278, 4 sheets, scale 1:250,000.

Parsons, Myles L., 1970, Groundwater thermal regime in a glacial complex: Water Resources Research, v. 6, no. 6, p. 1701-1720.

Prudic, D.E., 1982, Hydraulic conductivity of a finegrained till, Cattaraugus County, New York: Ground Water, v. 20, no. 2, p. 194-204.

Raleigh, R.F., 1982, Habitat suitability index models: Brook trout: U.S. Department of the Interior, Fish and Wildlife Service, RWS/OBS-82/10.24, 42 p.

Raleigh, R.F., Zuckerman, L.D., and Nelson, P.C., 1986, Habitat suitability index models and instream flow suitability curves: Brown trout, revised: U.S. Fish and Wildlife Service, Biological Report 82(10.124), 65 p.

Ruhl, J.F., 1989, Water Resources of the White Earth Indian Reservation, Northwestern Minnesota: U.S. Geological Survey Water-Resources Investigations Report 89-4074, 73 p.

Schoellhamer, D.H., and Jobson, H.E., 1986, Programmers manual for a one- dimensional Lagrangian transport model: U.S. Geological Survey Water- Resources Investigations Report 86-4144, 101 p.
Searcy, J.K., 1959, Flow-duration curves, Manual of Hydrology: Part 2, Low- Flow Techniques: U.S. Geological Survey Water-Supply Paper 1542-1, $33 \mathrm{p}$.

Searcy, J.K., and Hardison, C.H., 1960, Double-mass curves, Manual of Hydrology: Part 1., General surface-water techniques: U.S. Geological Survey Water-Supply Paper 1541-B, 66 p.

Siegel, D.I., and Winter, T. C., 1980, Hydrologic setting of Williams Lake, Hubbard County, Minnesota: U.S. Geological Survey Open-File Report 76-81, $237 \mathrm{p}$.

Sims, P.K., 1970, Geologic Map of Minnesota: Minnesota Geological Survey Miscellaneous Map Series, Map M-1, 1 sheet, scale 1:1,000,000.

Stark, J.R., and Zwilling, D.R., 1989, Effects of groundwater withdrawals for irrigation on the quality of the Straight River, north-central Minnesota, U. S. Geological Survey Open-File Report 89-252, 2 p.

Swan, D.R., and Condie, R., 1983, Computation of the base-flow index: Water Resources Branch, Inland Water Directorate, Environment Canada, Ottawa, Ontario, 21 p.

Tasker, Gary D. and Burns, Alan W., 1974, Mathematical generalization of stream temperature in central New England: Water Resources Bulletin, v. 10, no. 6, p., 1133-1142.

Tornes, L.H., 1980, Preimpoundment water quality of the Wild Rice River, Norman County, Minnesota: U.S. Geological Survey Water-Resource Investigation 80-79, $36 \mathrm{p}$.

U.S. Environmental Protection Agency, 1986, Quality criteria for water 1986: EPA-440/5-86-001.

Wahl, K.L., and Wahl, T.L., 1988, Effects of regional ground-water level decline on streamflow in the Oklahoma Panhandle: Proceedings of the American Water Resources Association Symposium on Water-Use data for Water Resources Management, August 1988, p. 239-249.

Weeks, D.W., Ericson, D.W., and Holt, C.L.R., Jr., 1965, Hydrology of the Little Plover River Basin Portage County, Wisconsin and the effect of water resource development: U.S. Geological Survey WaterSupply Paper 1811, 78 p.

Weeks, E.P. and Strangland, H.G., 1971, Effects of irrigation on streamflow in the central sand plain of Wisconsin: U.S. Geological Survey Open-File Report, 113 p. 
Winchell, N.H., Grant, U.S., Todd, J.E., Upham, W., and Winchell, H.V., 1888, The geology of Minnesota: Minnesota Geology and National History Survey Final Report, v. 4,616 p.

Winchell, N.H., and Upham, W. 1888, The geology of Minnesota: Minnesota Geology Natural History Survey Final Report, v. 2, 695 p.

Wright, H.E., Jr., 1962, Role of the Wadena lobe in the Wisconsin glaciation of Minnesota: Geological Society America Bulletin, v. 73, p. 73-100.

Wright, H.E., Jr., 1972, Quaternary history of Minnesota: in P.K. Sims and G.B. Morey, eds., Geology of Minnesota: A Centennial Volume, Minnesota Geological Survey, p. 515-547.

Wright, H.E., Jr. and Ruhe, R.V., 1965, Glaciation of Minnesota and Iowa: in H.E. Wright and D.G. Frey, eds., The Quaternary of the United States, University Press, Princeton, New Jersey, p. 29-41. 
Supplemental Information 


\section{Stream Flow Velocity}

Dye tracers were used in a time-of-travel study conducted on the Straight River to aid in calibration of stream-transport models and to better define the flow characteristics of the stream. Time-of-travel refers to the movement of water or conservative waterborne solutes in a stream during steady or gradually-varied flow conditions (Kilpatrick and Wilson, 1989).

The measurement of travel time using dye tracers involves the injection of dye along the stream and measurement of dye concentrations downstream. When a fluorescent dye is used as a tracer, the degree of fluorescence can be determined with a fluorometer. The concentration of dye in the sample is directly proportional to its fluorescence.

The dispersion and mixing of dye in the stream takes place in three dimensions in the channel. Vertical mixing normally takes place first, and lateral mixing later, depending on stream characteristics and velocity variations. Longitudinal dispersion continues throughout the length of the stream. A plot of concentration against time defines the dye-response curve at each sampling site. Time-of-travel is the time required for movement of the dye between sampling sites.

A time-of-travel study was conducted at the Straight River during August 23 through August 25, 1988. The results of the study summarized in table 6 , indicate that the average velocity of the stream (about $0.5 \mathrm{ft} / \mathrm{s}$ ) is relatively uniform but increases slightly downstream.

\section{Ground-water-flow Model}

A ground-water-flow model was developed for this investigation to help understand regional flow in the hydrogeologic system, hydraulic properties of hydrologic units, and the interaction between the aquifers and the stream. The model was calibrated using hydraulic, waterlevel, and water-use data compiled during the investigation and is intended as a tool to help understand the hydrologic system, and not as a predictive model. The U.S. Geological Survey's modular ground-water flow

Table 6.--Summary of data from time-of-travel study of the Straight River, August 1988 [mi, mile; $\mathrm{ft}^{3} / \mathrm{s}$, cubic feet per second; $\mathrm{ft} / \mathrm{s}$, feet per second; $\mu \mathrm{g} / \mathrm{L}$, micrograms per liter]

\begin{tabular}{|c|c|c|c|c|c|c|c|c|}
\hline \multirow{2}{*}{ River Reach } & \multirow{2}{*}{$\begin{array}{l}\text { Reach length } \\
\text { (mi) }\end{array}$} & \multirow{2}{*}{$\begin{array}{l}\text { Discharge } \\
\left(\mathrm{ft}^{3} / \mathrm{s}\right)\end{array}$} & \multicolumn{2}{|c|}{$\begin{array}{l}\text { Travel time } \\
\text { (hours) }\end{array}$} & \multirow{2}{*}{$\begin{array}{c}\text { Trailing } 5 \\
\text { percent }\end{array}$} & \multirow{2}{*}{$\begin{array}{l}\text { Velocity } \\
\text { of } \\
\text { centroid } \\
(\mathrm{ft} / \mathrm{s})\end{array}$} & \multirow{2}{*}{$\begin{array}{c}\text { Peak } \\
\text { concentraion } \\
(\mu \mathrm{g} / \mathrm{L})\end{array}$} & \multirow{2}{*}{$\begin{array}{l}\text { Dye } \\
\text { recovery } \\
\text { (percent) }\end{array}$} \\
\hline & & & leading & centroid & & & & \\
\hline $\begin{array}{l}\text { Minnesota Highway } \\
1_{34} \text { to Becker } \\
\text { County Highway } 123 \\
\text { (center of stream) }\end{array}$ & 1.36 & 25.5 & 2.78 & 4.33 & 6.97 & 0.46 & 7.53 & 94 \\
\hline $\begin{array}{l}\text { Minnesota Highway } \\
1_{34} \text { to Becker } \\
\text { County Highway } 123 \\
\text { (right bank) }\end{array}$ & 1.36 & 25.5 & 2.78 & 4.20 & 5.27 & .47 & 7.27 & 60 \\
\hline $\begin{array}{l}\text { County Highway } 123 \text { to } \\
\text { Station } \# 05243721\end{array}$ & 3.30 & 32.4 & 10.25 & 12.80 & 19.03 & .38 & 1.90 & 89 \\
\hline $\begin{array}{l}\text { Station \# }{ }^{2} 05243721 \text { to } \\
\text { Station \#05343722 }\end{array}$ & 3.40 & 36.6 & 7.87 & 11.12 & 17.00 & .45 & 2.90 & 64 \\
\hline $\begin{array}{l}\text { Station \# } 05343722 \text { to } \\
\text { Station \# } 05243723\end{array}$ & 2.86 & 42.7 & 8.03 & 8.93 & 11.67 & .47 & 1.40 & 63 \\
\hline $\begin{array}{l}\text { Station \# }{ }^{3} 05243723 \text { to } \\
\text { Station } 05243724 \\
\text { (center of stream) }\end{array}$ & 1.20 & 40.3 & 2.30 & 3.03 & 4.27 & .58 & 5.42 & 70 \\
\hline $\begin{array}{l}\text { Station \# } \text { \# }^{3} 05243723 \text { to } \\
\text { Station } 05243724 \\
\text { (left bank) }\end{array}$ & 1.20 & 40.3 & 2.30 & 3.03 & 4.27 & .58 & 5.42 & 70 \\
\hline $\begin{array}{l}\text { Station \# } 05243724 \text { to } \\
\text { Station \# } 05243725\end{array}$ & 2.12 & 47.2 & 4.33 & 5.41 & 7.05 & .57 & 2.17 & 84 \\
\hline
\end{tabular}

1 Dye injected at 0600 hours on 08-25-88 (150 ml-20\% Rhodamine W.T.)

2 Dye injected at 1100 hours on 08-25-88 (150 ml-20\% Rhodamine W.T.)

3 Dye injected at 1600 hours on $08-25-88$ (150 ml-20\% Rhodamine W.T.) 
model (McDonald and Harbaugh, 1988) was used. The model options used for simulations included the basic, block-centered flow, river, well, recharge, and strongly implicit model packages. The model uses natural hydrologic boundaries (streams and ground-water divides) tosimulate the ground-watersystem (figs. 29-31). Model cells are small along the stream to more accurately simulate the exchange of water between the stream and the ground-water system. Model cells were expanded in size away from thestream. The model simulates horizontal and vertical ground-water flow in the surficial aquifer (layer 1), in the uppermost confining unit (layer 2), in the uppermost confined-drift aquifer (layer 3 ) and vertical flow through the streambed.

Once calibrated to the assumed steady-state hydrologic conditions of August 1988, the model was used to analyze ground-water discharge to the stream and to indicate the amount of decline in potentiometric head, changes in the direction and rate of movement of ground water, and decrease in streamflow that might result from increased ground-water withdrawal.

\section{Model representation}

The model solves a finite-difference approximation to the ground-water-flow equation in three dimensions, given in equation 1.

$$
\frac{\partial}{\partial x} K x x \frac{\partial h}{\partial x}+\frac{\partial}{\partial y} K y y \frac{\partial h}{\partial y}+\frac{\partial}{\partial z} K z z \frac{\partial h}{\partial z}-W=S s \frac{\partial h}{\partial t}
$$

where

$\mathrm{x}, \mathrm{y}$ and $\mathrm{z}$ are Cartesian coordinates aligned along the major axes of hydraulic conductivity $\mathrm{Kxx}, \mathrm{Kyy}, \mathrm{Kzz}[\mathrm{L} / \mathrm{t}]$,

$h$ is the hydraulic head [L],

$\mathrm{W}$ is a volumetric flux per unit volume and represents sources and/or sinks of water $\left[\mathrm{t}^{-1}\right]$,

Ss is the specific storage of the porous material (Ss is zero for steady-state simulations) $\left[\mathrm{L}^{-1}\right]$, and $t$ is time [ $t]$.

The equation governs the simulated flow of water through aquifers and confining units in relation to aquifer characteristics and boundary conditions. A conceptually-based, physical model with simplifying assumptions about the ground-water system was formulated to aid in the development of the model. The conceptually based model consists of a qualitative description of the known characteristics and behavior of the hydrologic system. The major assumptions associated with the model are as follows:
1. The surficial aquifer, the uppermost confining unit, and the uppermost confined-drift aquifer (fig. 2) are represented as model layers 1,2 , and 3, respectively.

2. Drift (including aquifers and confining units) below the uppermost confined-drift aquifer are assumed to form an impermeable lower boundary and are not simulated.

3. Aquifers and the uppermost confining unit are simulated as homogeneous and isotropic.

4. Water levels in major surface-water bodies are relatively stable with time and are simulated as leaky cells or as constant-head cells.

5. Net recharge to the water table is from infiltration (less evapotranspiration) and can be varied depending upon the type of surficial material. Evapotranspiration is accounted for by using a net value of recharge (net recharge $=$ recharge - evapotranspiration).

6. Leakage to and discharge from the uppermost confined-drift aquifer is through the uppermost confining unit. The leakage is dependent on vertical hydraulic conductivity and thickness of the confining unit, and on hydraulic head in adjacent aquifers.

7. Ground-water pumped from wells is not returned to the aquifer system. Although some applied irrigation water probably does percolate back to the water table, this amount was not estimated, and thus the effect of percolation of irrigated water on ground-water temperature was not determined.

\section{Model design}

The model represents steady-state ground-water flow by computing hydraulic head over the extent of the surficial aquifer or surrounding areas that extend to the watershed boundaries. These boundaries are represented by no-flow cells (figs. 29-31). The active area of the model is about $82.6 \mathrm{mi}^{2}$. The active model grid contains 44 rows and 64 columns. A uniform grid spacing of 1,320 $\mathrm{ft}$ on each side was used for most of the modeled area. This grid was not precise enough to accurately simulate the area of the Straight River and grid cells were reduced in size to $820 \mathrm{ft}$ by $1,320 \mathrm{ft}$ in these areas. The upper portion of the drift system was divided into three model layers: (1) layer 1 (the top layer) represents the surficial aquifer, (2) layer 2 represents the uppermost confining unit; and (3) layer 3 represents the uppermost confineddrift aquifer.

Boundary conditions for layer 1 were chosen to simulate hydrologic boundaries (fig. 29). In layer 1 ground-water divides were simulated as no-flow cells. The Straight River was simulated by head-dependent-flux cells. The Shell River was represented as a no-flow 


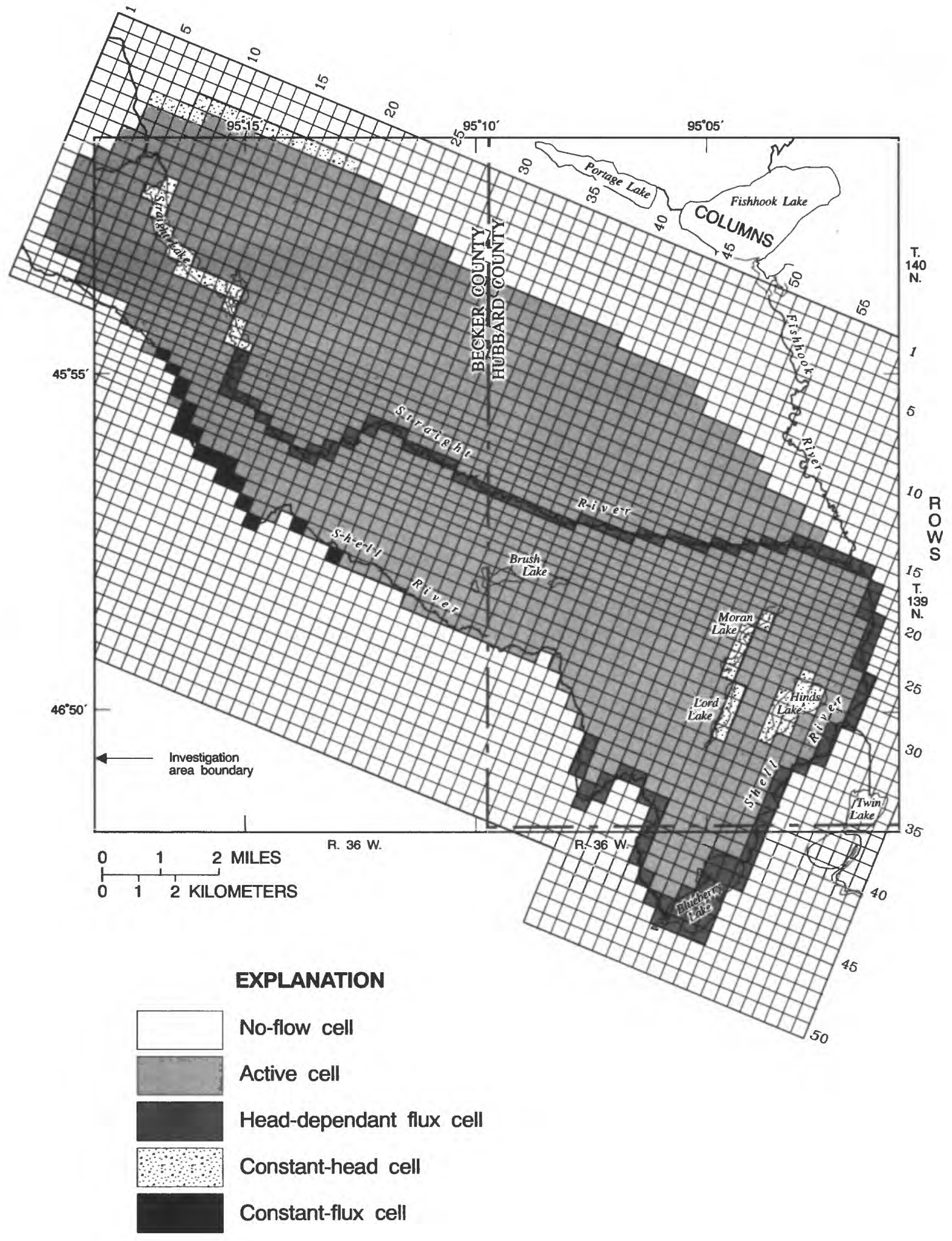

Figure 29.--Areal extent, finite-difference grid, and boundary conditions for layer 1 of ground-water-filow model. 


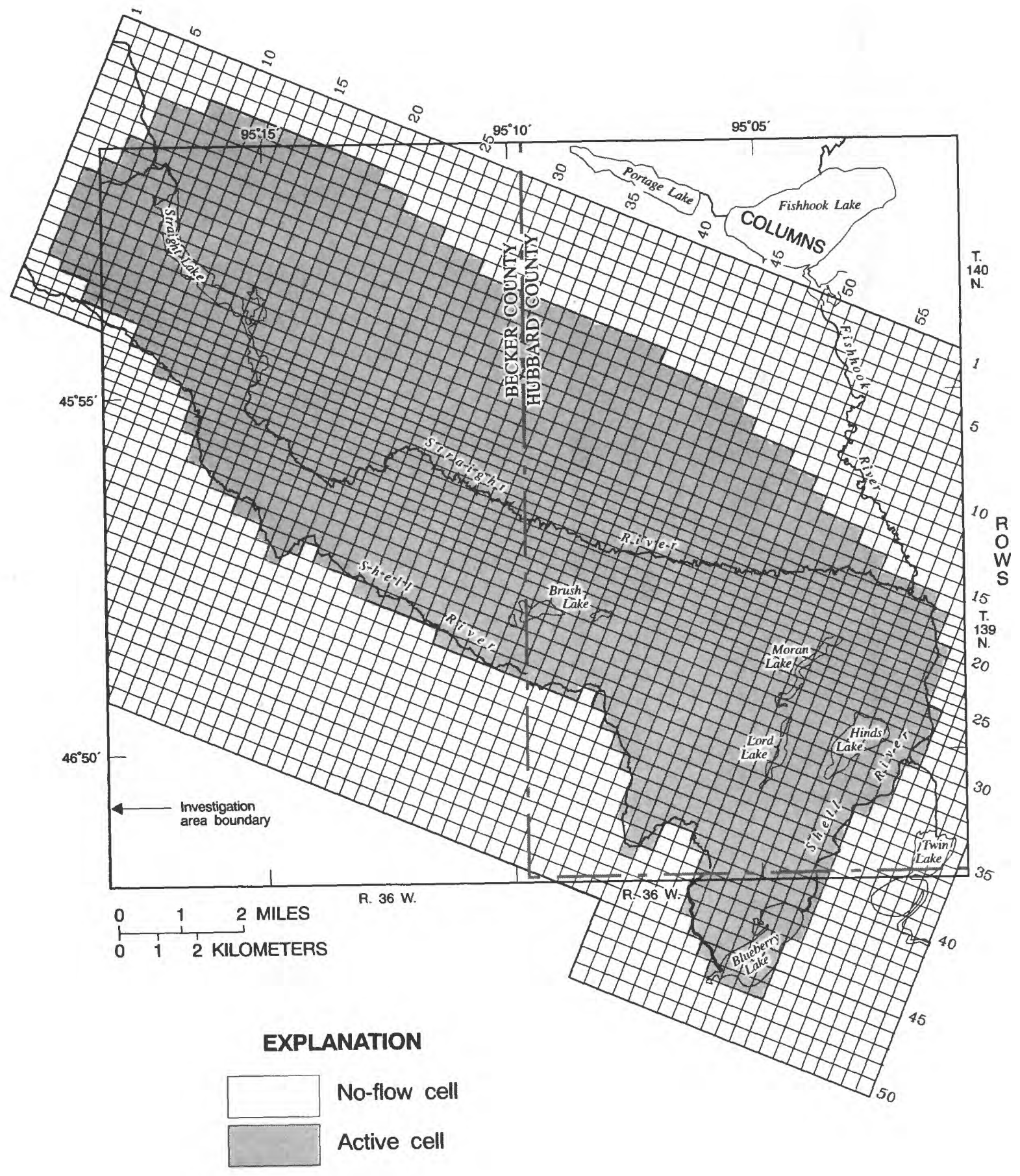

Figure 30.--Areal extent, finite-difference grid, and boundary conditions for layer $\mathbf{2}$ of ground-water-flow model. 


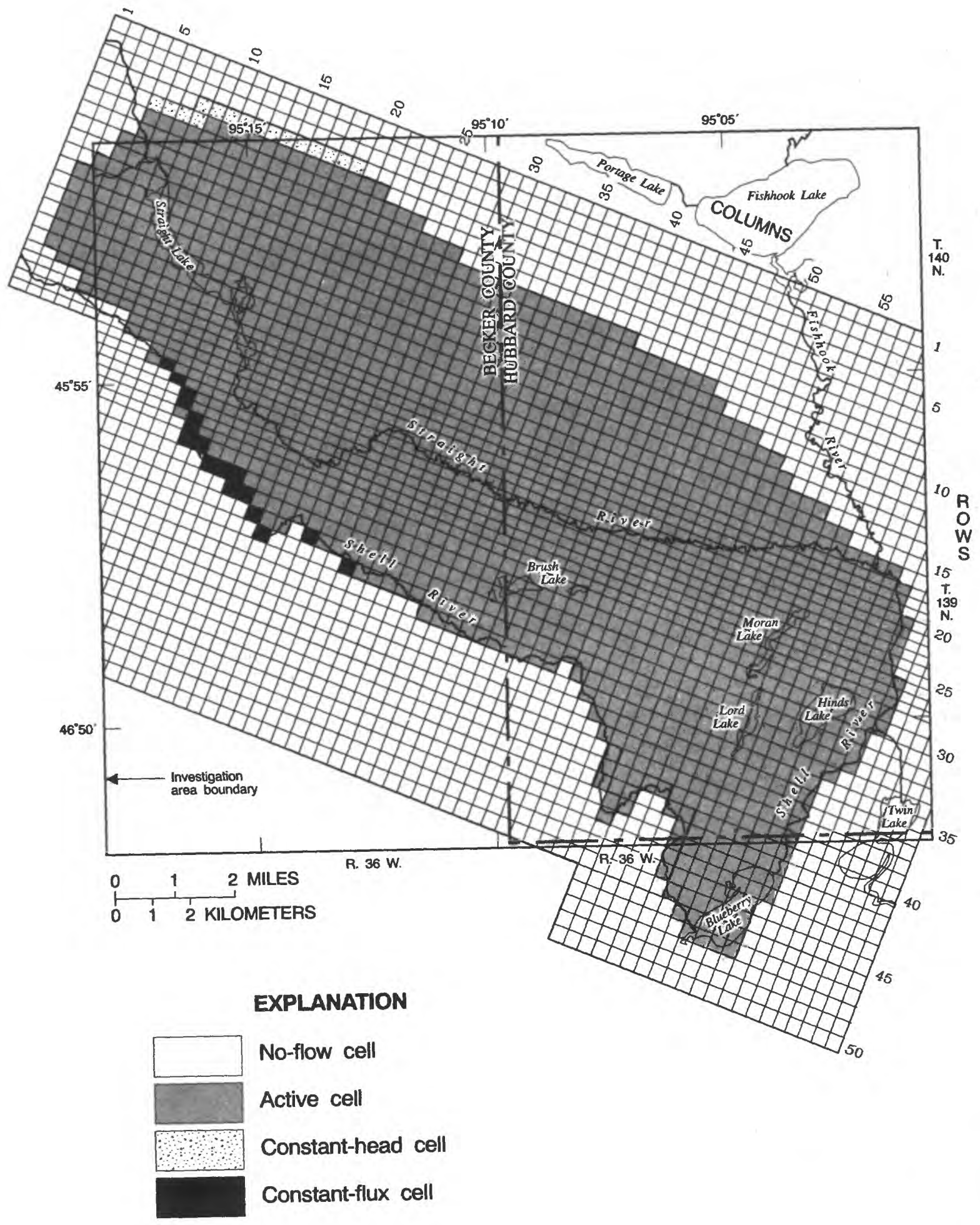

Figure 31.-Areal extent, finite-difference grid, and boundary conditions for layer 3 of ground-water-fiow model. 
boundary where the stream was hydraulically isolated from the aquifers because till was exposed at land surface and ground-water movement was parallel to the Shell River. The Shell River was represented by headdependent flux cells in areas where the stream is a discharge boundary. Constant-flux cells were used to simulate underflow into the ground-water basin, from the southwest. This underflow was estimated to be about 5.5 $\mathrm{ft}^{3} / \mathrm{s}$ based on calculations using Darcy's Law. Major lakes, including Straight Lake, were simulated as constant-head cells. Constant-head cells also were used to simulate inflow to the model in an area north of Straight Lake where the aquifer extends beyond the investigation area. It was assumed that assigned head values at boundaries represent an average potentiometric-surface condition over time.

Cell conditions for layer 2 consisted of active and noflow cells (fig. 30). Boundary-cell conditions for layer 3 (fig. 31) consisted of active cells, no-flow cells (representing the limits of the uppermost confined-drift aquifer), constant-flux cells (simulating underflow into the ground-water basin from the southwest $\left(2.4 \mathrm{ft}^{3} / \mathrm{s}\right)$ based on calculations using Darcy's law), and constanthead cells (representing inflow to the model in an area north of Straight Lake).

Geologic and hydrologic data compiled for this investigation were used to assign hydrogeologic characteristics to model cells. These data include the altitude of the top of the uppermost confining unit (fig. 16), potentiometric surfaces of the surficial and uppermost confined-drift aquifers (figs. 15 and 22), the altitude of the top of the uppermostconfined-drift aquifer (fig. 20) and the thickness of the uppermost confined-drift aquifer (fig. 21). Initial values of hydraulic properties for the model hydrogeologic units were estimated from data prepared for this investigation or adopted from published reports. Initial recharge rates were estimated by combining the total amount of stream base flow (tab. 5) and water withdrawn for irrigation. Ground-water withdrawal rates were compiled from data provided by the MDNR and results of data collected for this investigation, and were simulated as $2.5 \times 10^{6} \mathrm{ft}^{3} / \mathrm{d}$ which represents the average irrigation-application rate during the four-month summer (1988) period (tab. 7).

\section{Sensitivity analysis and model evaluation}

Sensitivity analysis was conducted to identify model variables that have the greatest effect on simulated potentiometric heads and simulated discharge to streams. This analysis identified the variables to which the model
Table 7.--Withdrawal rates for model cells representing high-capacity production wells in the investigation area used during simulations of fourmonth 1988 summer period [gal/min, gallons per minute]

\begin{tabular}{|c|c|c|c|}
\hline Layer & Row & Column & $\begin{array}{l}\text { Irrigation withdrawal } \\
\text { (gal/min) }\end{array}$ \\
\hline$T$ & 13 & 32 & 90.65 \\
\hline 1 & 14 & 6 & 262.3 \\
\hline 1 & 15 & 4 & 98.63 \\
\hline 1 & 15 & 29 & 355.8 \\
\hline 1 & 15 & 30 & 202.8 \\
\hline 1 & 15 & 31 & 72.65 \\
\hline 1 & 15 & 35 & 229.2 \\
\hline 1 & 15 & 44 & 26.8 \\
\hline 1 & 15 & 46 & 429.7 \\
\hline 1 & 16 & 7 & 163.4 \\
\hline 1 & 16 & 30 & 342.4 \\
\hline 1 & 16 & 37 & 364.5 \\
\hline 1 & 16 & 39 & 283.9 \\
\hline 1 & 16 & 46 & 310.8 \\
\hline 1 & 16 & 49 & 150.0 \\
\hline 1 & 17 & 5 & 328.5 \\
\hline 1 & 18 & 26 & 235.6 \\
\hline 1 & 19 & 11 & 373.4 \\
\hline 1 & 19 & 32 & 168.9 \\
\hline 1 & 22 & 49 & 221.5 \\
\hline 1 & 26 & 26 & 111.8 \\
\hline 1 & 26 & 33 & 121.6 \\
\hline 1 & 27 & 19 & 74.07 \\
\hline 3 & 9 & 42 & 297.5 \\
\hline 3 & 9 & 44 & 218.6 \\
\hline 3 & 13 & 30 & 262.7 \\
\hline 3 & 13 & 49 & 426.9 \\
\hline 3 & 13 & 52 & 112.8 \\
\hline 3 & 14 & 54 & 1235 \\
\hline 3 & 17 & 35 & 327.4 \\
\hline 3 & 17 & 38 & 223.1 \\
\hline 3 & 18 & 9 & 271.9 \\
\hline 3 & 18 & 34 & 192.8 \\
\hline 3 & 18 & 40 & 245.6 \\
\hline 3 & 18 & 41 & 386.8 \\
\hline 3 & 19 & 25 & 607.3 \\
\hline 3 & 19 & 36 & 511.7 \\
\hline 3 & 19 & 42 & 264.1 \\
\hline 3 & 20 & 12 & 542.0 \\
\hline 3 & 20 & 58 & 394.2 \\
\hline 3 & 20 & 60 & 210.1 \\
\hline 3 & 21 & 40 & 233.2 \\
\hline 3 & 21 & 56 & 238.0 \\
\hline 3 & 22 & 50 & 184.5 \\
\hline 3 & 22 & 51 & 190.6 \\
\hline 3 & 23 & 28 & 324.7 \\
\hline 3 & 24 & 53 & 127.9 \\
\hline 3 & 29 & 17 & 79.89 \\
\hline
\end{tabular}


was most sensitive, and therefore indicated types of additional data collection or model refinement that would most improve the model simulation of the hydrologic system.

Sensitivity analysis (based on comparisons between sensitivity-simulation results and a model-simulation using "best estimates" of hydrologic values, S1 in tab. 8) indicated that recharge, horizontal hydraulic conductivity of model layer 1 , and horizontal hydraulic conductivity of model layer 3 were the variables that most affected model-simulated hydraulic heads and model-simulated discharge to streams and lakes (tab. 8). A total of 30 model cells were used to compare simulated hydraulic head in model layer 1 with measured hydraulic head in the surficial aquifer. A total of 9 cells were used for comparison of model layer 3 with measured hydraulic head in the uppermost confined-drift aquifer. Measured base-flow gain to the stream at three locations (sites B, D and F-fig. 5) also was used to compare to simulated streamflow gain.

The model also was tested to determine the range of values of hydrologic properties that provide simulated potentiometric heads and simulated stream discharge that best match those measured in the field. This process consisted of adjusting values of sensitive hydrologic properties (recharge and horizontal hydraulic conductivity of model layers 1 and 3 ) within realistic limits (based on ranges in published values) until simulated potentiometric heads and simulated groundwater discharge to the Straight River acceptably matched corresponding measured values. This combination of values, however, is not unique and other combinations of values could produce similar results.

Ground-water discharge to the Straight River and measured water-level elevations in selected wells were used to determine whether model-simulated output was acceptable. Base-flow discharge to the Straight River was measured at selected sites during the summer of 1988 and was compared to model-simulated ground-water discharge to the stream under steady-state conditions representing the summer of 1988 . Measured streamflow in the Straight River at three locations (at Becker County Highway 125 (site B), at Hubbard County Highway 115 (site D), and at State Highway 71 (site F)) averaged 13, 24 , and $29 \mathrm{ft}^{3} / \mathrm{s}$, respectively during the summer of 1988 . This compared with model-calculated streamflow at cells representing those locations (cells $(21,27),(22,44)$, and $(18,54))$ of 15,27 , and $30 \mathrm{ft}^{3} / \mathrm{s}$, respectively. Other criteria used to evaluate model variables were the mean difference between model-simulated hydraulic heads in layers 1 and 3 of the model and measured hydraulic head in wells completed in the surficial and uppermost confined-drift aquifers. Because the model was used to improve the understanding of the regional flow system (as opposed to simulating local hydrologic conditions) model variables were not changed locally to produce a better match. A difference between simulated and measured head of $1 \mathrm{ft}$ was arbitrarily chosen as an acceptable match. The distribution of model-simulated heads was in general agreement with the measured-head distribution (figs. 15 and 22). Model-computed hydraulic heads at 30 cells in model layer 1 averaged $0.10 \mathrm{ft}$ less than hydraulic heads measured during the summer of 1988 in wells completed in the surficial aquifer in areas represented by those model cells. Maximum and minimum differences between model-simulated and measured hydraulic heads at individual cells were -20.74 and $+12.63 \mathrm{ft}$ in cells in model layer 1. Model-simulated hydraulic heads at 9 cells in model layer 3 averaged $0.67 \mathrm{ft}$ less than hydraulic heads measured during the summer of 1988 in wells completed in areas represented by those model cells in the uppermost confined-drift aquifer. Maximum and minimum differences were -7.05 and $+11.82 \mathrm{ft}$, respectively.

Values of horizontal hydraulic conductivity were estimated by varying the horizontal hydraulic conductivity in model cells representing the two aquifers (model layers 1 and 3) and in the uppermost confining unit (model layer 2). Values of horizontal hydraulic conductivity of 255 and $300 \mathrm{ft} / \mathrm{d}$ for the surficial and uppermost confined-drift aquifers, respectively, were found to provide acceptable results (tab. 9). The uppermost confining unit was simulated as having a horizontal hydraulic conductivity of $2.0 \mathrm{ft} / \mathrm{d}$., and glacial till exposed at land surface (layer 1) was simulated as having a horizontal hydraulic conductivity of $12 \mathrm{ft} / \mathrm{d}$. Vertical hydraulic conductivity values were changed in a similar manner. A value of $0.2 \mathrm{ft} / \mathrm{d}$ was considered an acceptable value of vertical hydraulic conductivity for the uppermost confining unit (layer 2) and values of 20 and 4 $\mathrm{ft} / \mathrm{d}$ were considered to be acceptable for the surficial and uppermost confined-drift aquifers, respectively. Values of vertical streambed hydraulic conductivity were estimated by changing the model values for vertical hydraulic conductivity, assuming the streambed had a uniform thickness of $1 \mathrm{ft}$. The resulting value was found to be approximately $2.0 \mathrm{ft} / \mathrm{d}$.

\section{Results of model simulation}

A water budget is an accounting of inflow, outflow, and changes in storage in a ground-water system. For steadystate simulations inflow (sources) to and outflow (discharges) from the system are equal and there are no long-term changes in storage. For this investigation the ground-water system was assumed to approach steady- 
Table 8.--Sensitivity of hydraulic heads in the surficial and uppermost confined-drift aquifers (model layers 1 and 3 ) to changes in values of model variables, Straight River Basin, Minnesota $\left[\mathrm{tt}^{3} / \mathrm{s}\right.$, cubic feet per second; -, computed head was less than head measured in the field;

", model simulation was numerically unstable; NA, not available]

\begin{tabular}{|c|c|c|c|c|c|}
\hline \multirow{5}{*}{$\begin{array}{c}\text { Hydraulic property } \\
\text { [Simulation number] (value of } \\
\text { multiplication factor for } \\
\text { hydraulic property) }\end{array}$} & \multicolumn{2}{|c|}{$\begin{array}{l}\text { Mean error in computed heads between } \\
\text { simulated and measured values of } \\
\text { potentiometric head (feet) }\end{array}$} & \multicolumn{3}{|c|}{$\begin{array}{l}\text { Model-computed stream gain along stream reach } \\
\text { above indicated site }\left(\mathrm{ft}^{3} / \mathrm{s}\right)\end{array}$} \\
\hline & \multirow[b]{4}{*}{ Layer 1} & \multirow[b]{4}{*}{ Layer 3} & $\begin{array}{c}\text { Cell } \\
\text { (row } 21 \text { column }\end{array}$ & $\begin{array}{c}\text { Cell } \\
\text { (row 22, column }\end{array}$ & $\begin{array}{c}\text { Cell } \\
\text { ow } 18 \text {, column }\end{array}$ \\
\hline & & & 27) at County & 44) at County & 54) at State \\
\hline & & & Highway 125 & Highway 115 & Highway 71 \\
\hline & & & (site B) & (site D) & (site F) \\
\hline \multicolumn{6}{|c|}{ Recharge to modellayer (Inches per year) } \\
\hline [S1] 12.5 & 0.8 & -3.0 & 16.5 & 49 & 55 \\
\hline [S6] 25.0 & 8.2 & 3.3 & 29 & 65 & 80 \\
\hline \multirow{2}{*}{\multicolumn{6}{|c|}{ Values of horizontal hydraulic conductivity of model layer 1 (feet/day) }} \\
\hline & & & & & \\
\hline [S1] 510 & .8 & -3.0 & 16.5 & 49 & 55 \\
\hline [S2] 255 & 4.6 & .2 & 15 & 30 & 35 \\
\hline [S4] 1020 & * & * & * & * & * \\
\hline [S5] $765 \ldots$ & & * & * & * & * \\
\hline \multicolumn{6}{|c|}{ Values of horizontal hydraulic conductivity of model layer 3 (feet/day) } \\
\hline [S1] 215 & .8 & -3.0 & 16.5 & 49 & 55 \\
\hline [S8] 107 & 2.0 & -5.4 & NA & NA & NA \\
\hline [S9] 430 & -.5 & 2.0 & 17 & 34 & 38 \\
\hline \multirow{2}{*}{\multicolumn{6}{|c|}{$\begin{array}{l}\text { Factor of change in vertical conductance b } \\
\text { Between model layers } 1 \text { and } 2\end{array}$}} \\
\hline & & & & & \\
\hline [S1] 1.0 & .8 & -3.0 & 16.5 & 49 & 55 \\
\hline [S17] .1 & * & $*$ & $*$ & * & * \\
\hline [S10] $\quad .5$ & * & * & & & * \\
\hline [S11] 2.0 & .6 & -2.7 & NA & NA & NA \\
\hline \multirow{2}{*}{\multicolumn{6}{|c|}{ Between model layers 2 and 3}} \\
\hline & & & & & \\
\hline [S1] 1.0 & .8 & -3.0 & 16.5 & 49 & \\
\hline [S14] .1 & 1.6 & -5.5 & NA & NA & NA \\
\hline$\left[\begin{array}{lll}S & 13\end{array}\right] .5$ & .7 & -3.8 & NA & NA & NA \\
\hline$[\mathrm{S} 12] 2.0$ & .7 & -2.6 & NA & NA & NA \\
\hline [S16] 10.0 & $*$ & & & * & * \\
\hline
\end{tabular}

Table 9.--Selected model-input parameters after calibration and used for hypothetical ground-water withdrawal and drought scenarios

$[-$, not calculated $]$

\begin{tabular}{lccccc}
\hline & Surficial aquifer & $\begin{array}{c}\text { Uppermost } \\
\text { confined-drift } \\
\text { aquifer }\end{array}$ & $\begin{array}{c}\text { Uppermost } \\
\text { confining unit }\end{array}$ & Glacial till & Stream bed \\
\hline $\begin{array}{l}\text { Net recharge } \\
\text { (inches/year) }\end{array}$ & 12.5 & - & - & 12.5 & -- \\
$\begin{array}{c}\text { Horizontal hydraulic } \\
\text { conductivity (feet/day) }\end{array}$ & 255 & 300 & 2.0 & 12 & -- \\
$\begin{array}{c}\text { Vertical hydraulic conductivity } \\
\text { (feet/day) }\end{array}$ & 20 & 4.0 & .2 & .1 & 2.0 \\
\hline
\end{tabular}


state conditions during the summer of 1988, and model results represented steady-state conditions for August 1988. A general equation of the steady-state water budget in the modeled area can be written as:

$$
P-R O-E T+G_{r s}+G_{i}=G_{d s}+G_{p}+G_{0}
$$

where:

$\mathbf{P}=$ precipitation $^{1}$;

RO = runoff ${ }^{1}$;

ET = evapotranspiration';

$\mathrm{G}_{\mathrm{rs}}=$ ground-water recharge from streams, lakes, and swamps;

$\mathrm{G}_{\mathrm{i}}=$ ground-water inflow;

$\mathrm{G}_{\mathrm{ds}}=$ ground-water discharge to streams, lakes, and swamps;

$\mathrm{G}_{\mathrm{p}}=$ ground-water pumpage;

$\mathrm{G}_{\mathrm{0}}=$ ground-water outflow.

${ }^{1}$ values are lumped in model recharge term

The steady-state water budget for the calibrated model (tab. 10) shows that net recharge from precipitation is the major source of water to the system. Leakage to streams and lakes accounts for most of the discharge from the ground-water system; however, withdrawal of ground water through wells is a major source of discharge from the modeled area for model simulations representing summer steady-state conditions.

\section{Table 10.--Model-computed water budget for the Straight River basin [ $\mathrm{ft}^{3} / \mathrm{s}$, cubic feet per second]}

\begin{tabular}{|c|c|c|}
\hline Budget component & Inputs $\left(\mathrm{ft}^{3} / \mathrm{s}\right)$ & Outputs $\left(\mathrm{ft}^{3} / \mathrm{s}\right)$ \\
\hline Net recharge ${ }^{1}$ & 71.5 & 0.0 \\
\hline Constant heads ${ }^{2}$ & 10.5 & 14.7 \\
\hline Stream and lake leakage & .90 & 47.6 \\
\hline Well discharge & 0 & 28.4 \\
\hline Constant flux ${ }^{3}$ & 7.89 & 0 \\
\hline Storage & 0 & 0 \\
\hline Total & 90.8 & 90.7 \\
\hline
\end{tabular}

${ }^{1}$ precipitation minus runoff and ground-water evaporation.

2 inflow and outflow from the ground-water system to lakes and rivers in certain areas and inflow to the model area from within the surface-water basin.

${ }^{3}$ flow into the model area as underflow from outside the surface-water drainage basin.

\section{Simulated effects of ground-water withdrawal}

Simulations were made to estimate the general effect of ground-water withdrawal on the ground-water system and ground-water discharge to the Straight River. These simulations used model-input values that provided values of simulated head of within $1 \mathrm{ft}$ of measured head and simulated stream discharge within 5 percent of stream discharge. The simulations indicate the following:

1. Simulations indicate that ground-water withdrawal for irrigation has potential to affect the quantity of flow in the stream. Results of model simulation further indicate that continued ground-water withdrawal from the aquifers at rates as great as those during 1988 might reduce stream discharge in the Straight River by as much as 34 percent of stream base flow compared to periods when there was no ground-water withdrawal for irrigation.

The effect of 1988 withdrawal by irrigation wells was simulated by comparing results of simulations of 1988 ground-water withdrawal with the simulation of a period with no ground-water withdrawal for irrigation. Results of the simulations indicate that with irrigation withdrawal the potentiometric surfaces in the surficial and uppermost confined-drift aquifers are reduced by an average of about 4 and $6 \mathrm{ft}$, respectively. The regional direction and rate of change in ground-water flow were minimal and net inflow of ground-water from constant-head cells changed by less than 2 percent when separate simulations were compared.

2. The effect of continued increase in the withdrawal of ground water for irrigation was simulated by doubling the withdrawal rate from all wells used in the summer 1988 simulation. Additional declines in the potentiometric surface averaged about 3 and $5 \mathrm{ft}$ in the surficial and uppermost confined-drift aquifers, respectively, as a result of these increases in withdrawals. Simulated stream discharge decreased by 53 percent of stream base flow compared to periods when there was no ground-water withdrawal for irrigation for the Straight River. Stream discharge in much of the lower reaches of the stream was captured by leakage to the ground-water system.

\section{Stream-Temperature Model}

A streamflow and stream-temperature model of the Straight River was developed to help understand hydrologic and meteorologic relations that are significant for determining the temperature of the stream. The model was not intended as a predictive model. The U.S. Geological Survey's one-dimensional Lagrangian Transport Model (LTM) (Schoellhamer and Jobson, 
1986) was used for these simulations. The model represents the Straight River from the outlet of Straight Lake downstream to U.S. Highway 71, near Park Rapids (fig. 1).

Several physical processes can be simulated with the LTM. These include: advection, dispersion, tributary or point-source mixing, and lateral-inflow mixing (groundwater inflow). Advection represents the movement of a constituent with the flow of water in a stream. Dispersion is the spreading out of a constituent in the longitudinal direction because of velocity variations within a stream. Tributary or point-source mixing and lateral-inflow mixing are used to simulate inputs of water and constituents from tributaries, point-sources and groundwater inflow. The change in constituent concentration due to dispersion is calculated with a basic mixing equation in the model.

The model was used to simulate steady-flow conditions and transient meteorological conditions. Simulation of these processes was accomplished by solving the advection-dispersion equation for a given set of boundary, initial, steady-flow, and transient meteorological conditions that were measured during this investigation. The advection-dispersion equation has been derived by considering the principle of conservation of mass and is solved by numeric approximation. The model uses a Lagrangian reference frame that moves the computational nodes, which simulate parcels of water moving down the stream. This technique eliminates the advection term from the advection-dispersion equation. As parcels pass both point and nonpoint sources, inflow is mixed and new parcel concentrations are computed.

Hydraulic inputs needed for simulation of steady-flow conditions are discharge at the upstream end of the stream reach, average cross-sectional properties (area, width), and ground-water inflow at each stream reach. In addition to hydraulic data, the model requires temperature data at the upstream end of each reach and heat flux at points of lateral inflow (ground water).

The temperature of the Straight River is a function of net solar radiation to and evaporation from the openwater surface, heat added to or lost from the stream by conduction and convection with the air, conduction to the earth, and the temperature and volume of ground water flowing in or out of the river. The net exchange of thermal energy between the atmosphere and water is the algebraic sum of the heat flux caused by incoming long-wave radiation, heat flux caused by evaporation, heat conducted from the water as sensible heat, and heat added or lost as rain falls directly on the surface.

Equilibrium temperature is defined as the temperature at which the net surface exchange of energy becomes zero because the heat gained from the sun and the sky plus conduction is balanced by the heat lost to back radiation and evaporation. It is easier to estimate the equilibrium temperature than to measure or estimate all of the meteorological parameters needed to compute the equilibrium temperature. When averaged over a day or more, the equilibrium temperature usually is found to be within about one or two degrees of the mean-daily temperature. The problem of temperature prediction in streams is thus reduced to the problem of estimation of the equilibrium temperature (H.E. Jobson, U.S. Geological Survey, written commun., 1989).

A stream-temperature algorithm (Jobson, 1980a) was used to simulate approximate stream temperature. Only equilibrium temperature and wind-speed data were required, and hourly-air temperature was used as an approximation of the equilibrium temperature (H.E. Jobson, U.S. Geological Survey, written commun., 1989).

The model was calibrated using hydraulic data (stream-discharge, stream-velocity, and channel crosssection data), meteorological data (air temperature), and ground-water temperature data collected during this investigation. Meteorological data collected for a U. S. Geological Survey study at Williams Lake, Minnesota, located about 20 miles east of the investigation area (Don Rosenberry, U. S. Geological Survey, written commun., 1990), and ground-water discharge information to the stream were from results of the ground-water-flow model.

The model is based on the discretization of the stream into several stream-reaches, separated by grid points. The stream was divided into 7 reaches for simulation. The reaches coincided with segments of the stream between major roads (fig. 5). These include stream reaches from one mile north of State Highway 34 to State Highway 34, from State Highway 34 to Becker County road 123, from Becker County road 123 to Becker County road 125 , from Becker County road 125 to Hubbard County road 117, from Hubbard County road 117 to Hubbard County road 115 , from Hubbard County road 115 , to U.S. Highway 71 , and from U.S. Highway 71 to the mouth of the Straight River. Available discharge and water temperature data for certain locations along several of these reaches were used to calibrate the model.

The model was calibrated in steps. The first step included evaluating the accuracy of the steady-state flow field. The cross-section areas of the stream were adjusted, within limits, until model-predicted stream velocity matched measured velocity (see Streamflow Velocity section of Supplemental Information). This was accomplished by adjusting the cross-section areas at the two upstream grid points and then by adjusting the next 
downstream cross-section area. After cross-section area and stream velocity combinations were determined, the width of the stream surface was adjusted. This was accomplished by dividing the width of the stream surface by the cross-section area to obtain average stream depths, and was completed by adjusting the width of the stream surface to represent either a measured or calculated average stream depth. The third step in the calibration process consisted of accounting for thermal dispersion. The final step was to adjust the decay rate. The calibration process (fig. 32) for the Straight River results in a simulated stream temperature that generally follows the same pattern as actual stream temperature during May through September 1988. Once calibrated to these conditions, the model was used to analyze the significance of a reduction in ground-water inflow to the stream on the temperature of the stream, and the significance of the temperature of outflow from Straight Lake Reservoir.

Ground-water inflow temperature, which averages about $7^{\circ} \mathrm{C}$ throughout the year, reduces the temperature of the Straight River during the summer. Model simulations were conducted to evaluate the potential effect of reduced ground-water inflow to the stream resulting from groundwater withdrawal for irrigation as determined from results of ground-water model simulations. In these simulations, model-input conditions were identical to conditions for simulations used to calibrate the model to measured stream conditions except that ground-water inflow was reduced by 34 percent. Results of the simluations indicate that a potential reduction in streamflow due to irrigation can increase stream temperature by 0.5 to $1.5^{\circ} \mathrm{C}$ (fig. 33). This potential increase can have an adverse effect on the habitat of the stream for trout. There currently is little evidence to

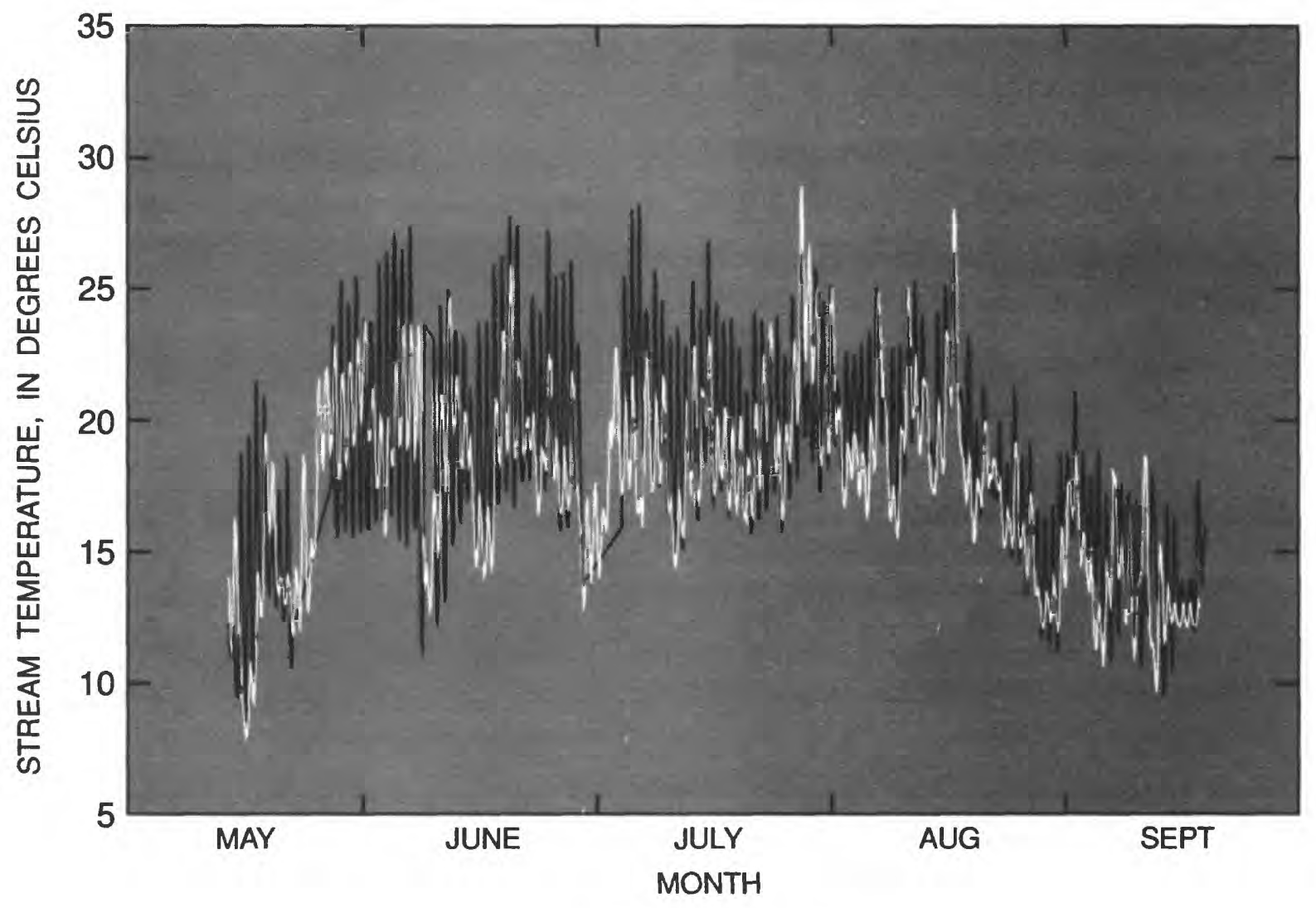

EXPLANATION

Measured stream temperature

Model-simulated stream temperature

Figure 32.-Measured and model-simulated stream temperature of Straight River (site B) at Becker County Road 125 during May through September 1988. 


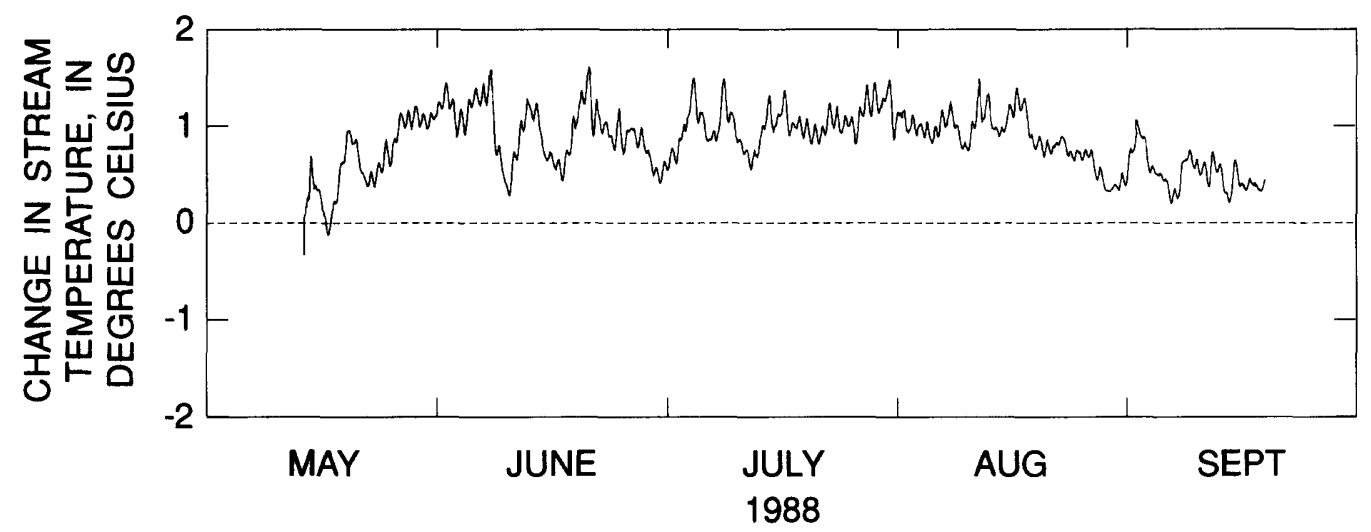

Figure 33.--Change in model-simulated temperature of Straight River at U.S. Highway 71 (site F) during May through September 1988, resulting from reduced base flow due to irrigation withdrawal of ground water, Straight River, Minnesota.

indicate, however, that irrigation is having a significant effect on ground-water temperature, or on the temperature of the Straight River.

The construction of the dam at Osage also may have resulted in increased temperature of the Straight River. Measurements of temperature in Straight Lake indicate that it ranges from about $22^{\circ} \mathrm{C}$ near the surface to about $10^{\circ} \mathrm{C}$ at depths of 45 feet below the lake surface during late summer. The effect of the dam, where outflow is from the surface, results in warm (lake-surface) water flowing into the stream below the dam. Model simulations of the stream, in which the temperature of water discharging from the lake was reduced by $5^{\circ} \mathrm{C}$, were conducted to represent possible bottom release of water from the dam. These simulations indicate that stream temperature could be reduced by as much as $1.3^{\circ} \mathrm{C}$, about three miles downstream from the dam, at site $\mathrm{B}$, if the outlet structure of the dam were changed (fig. 34). The reduction in stream temperture was found to be less significant downstream from site $B$.

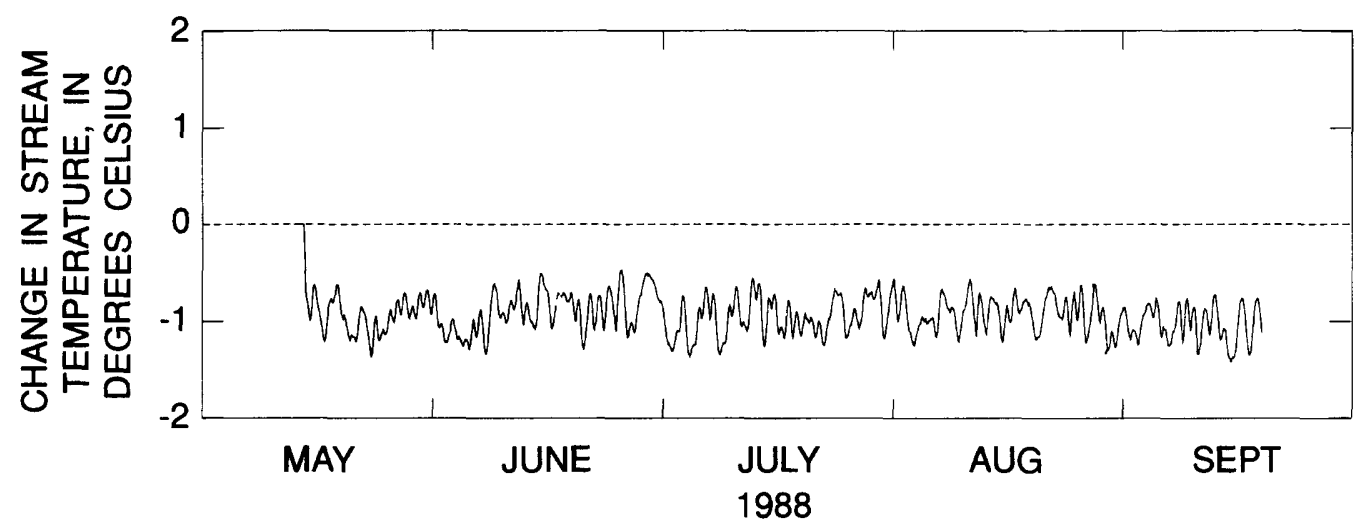

Figure 34.--Changes in model-simulated temperature of Straight River at Becker County Highway 125 (site B) during May through September 1988, resulting from a simulated 5-degree Celsius decrease in the temperature of discharge from Straight Lake. 


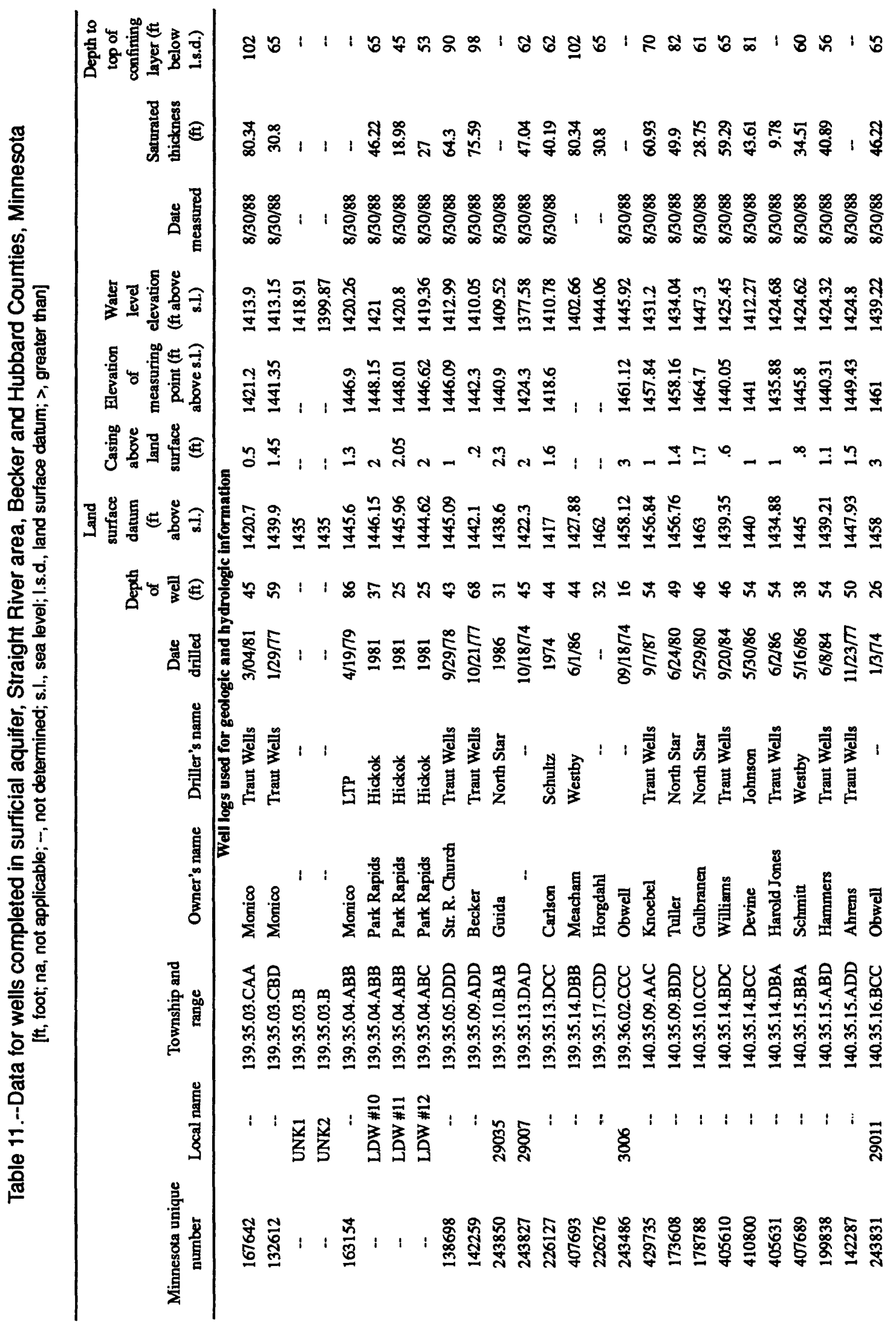




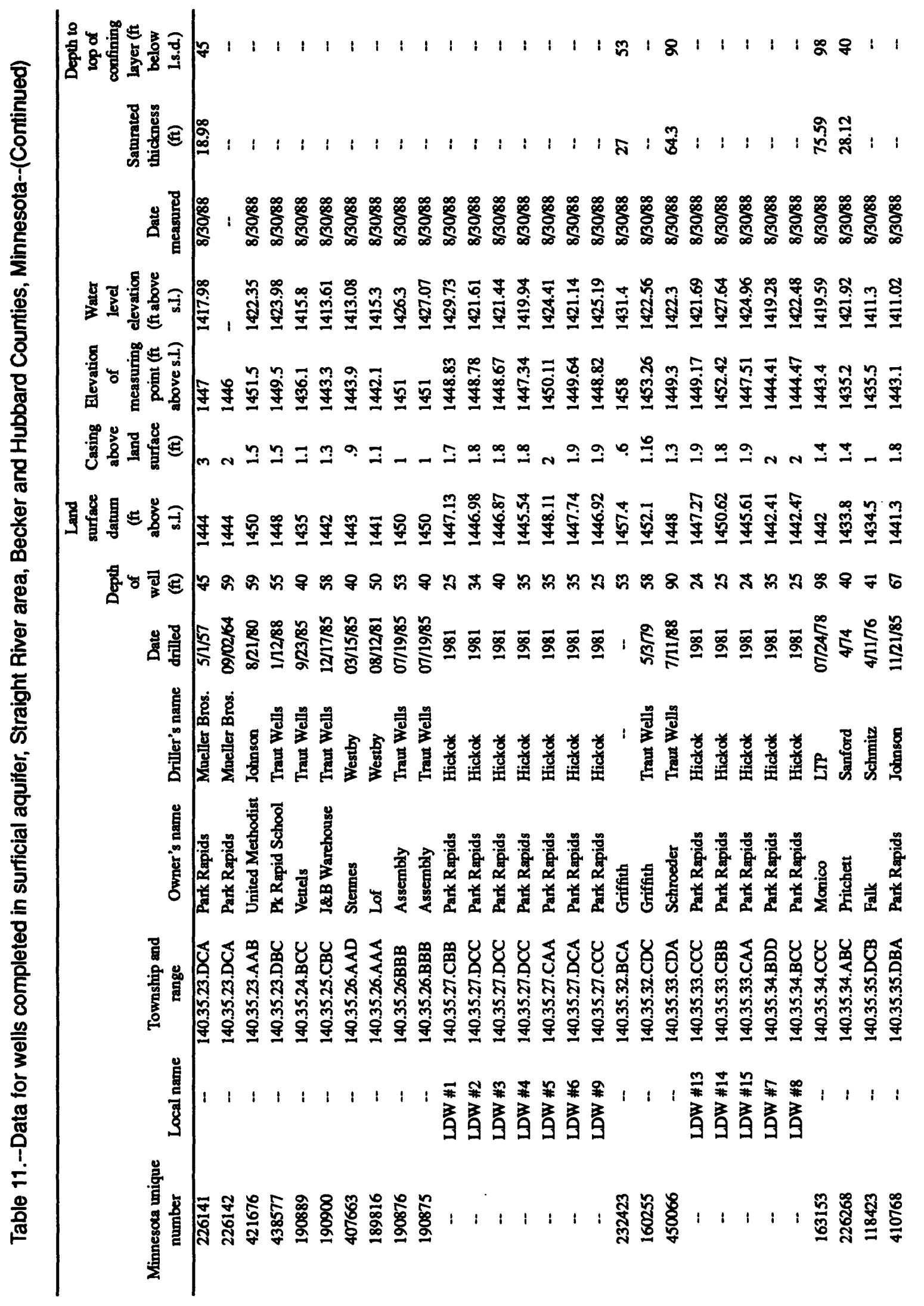




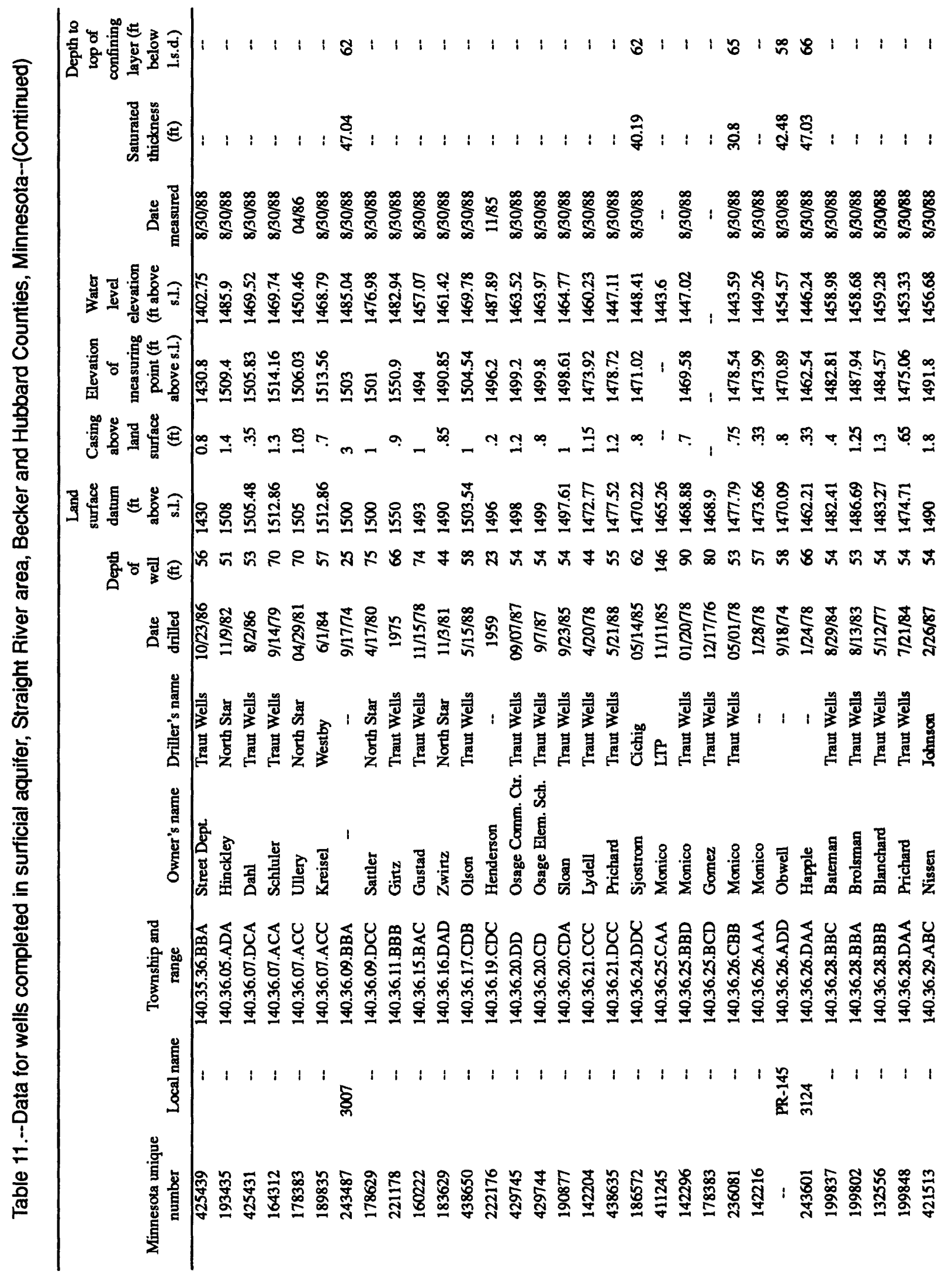




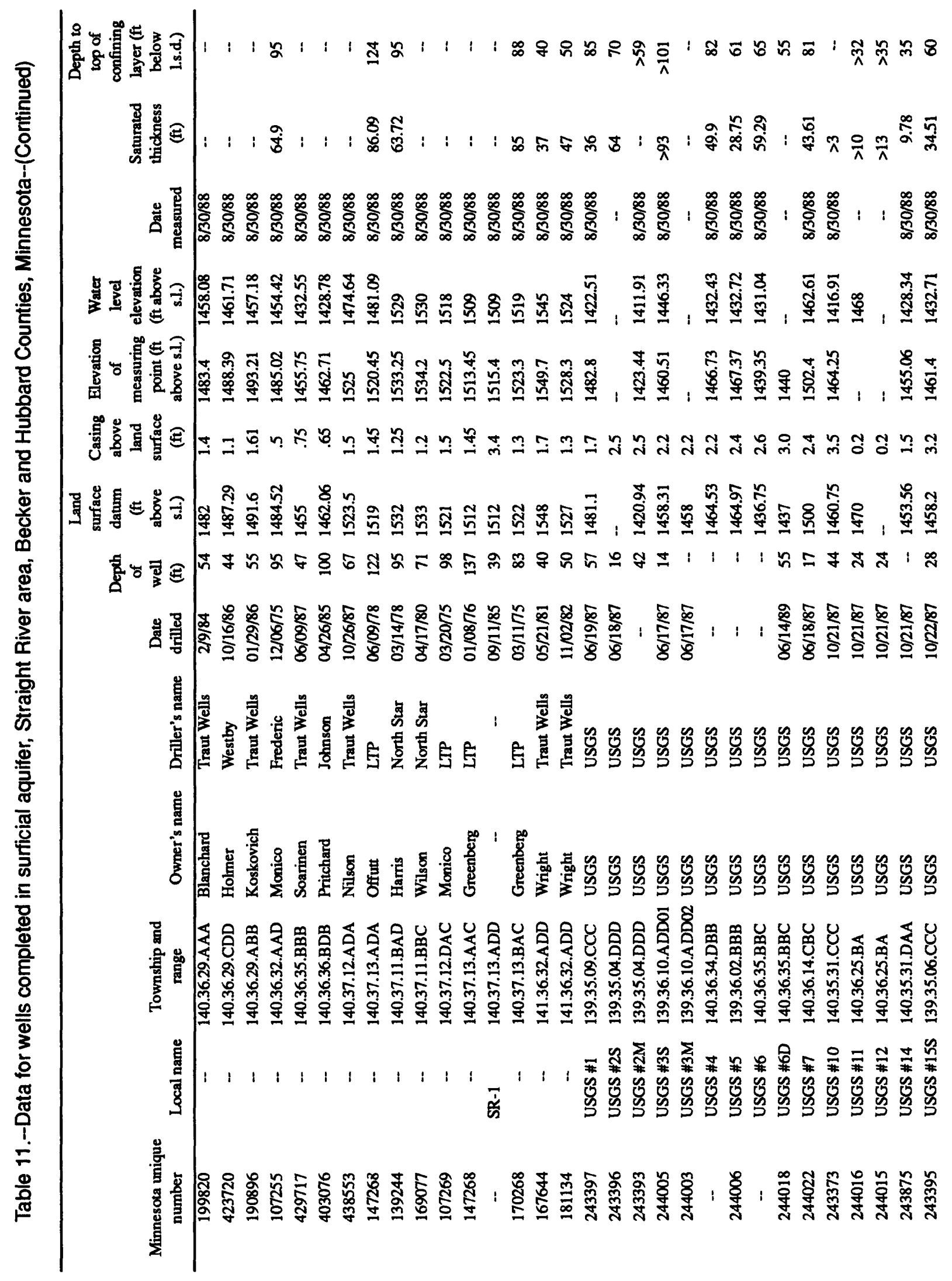




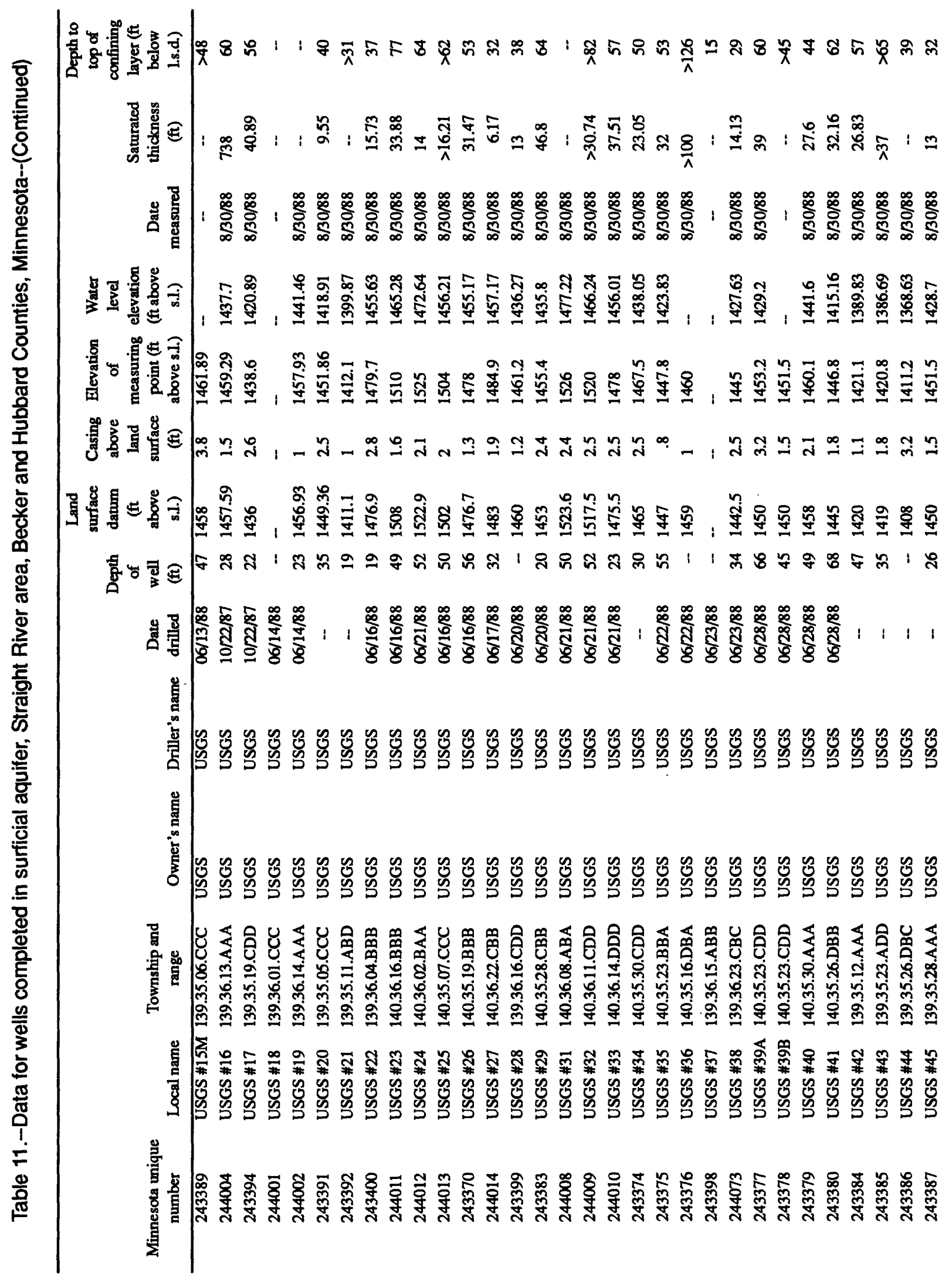




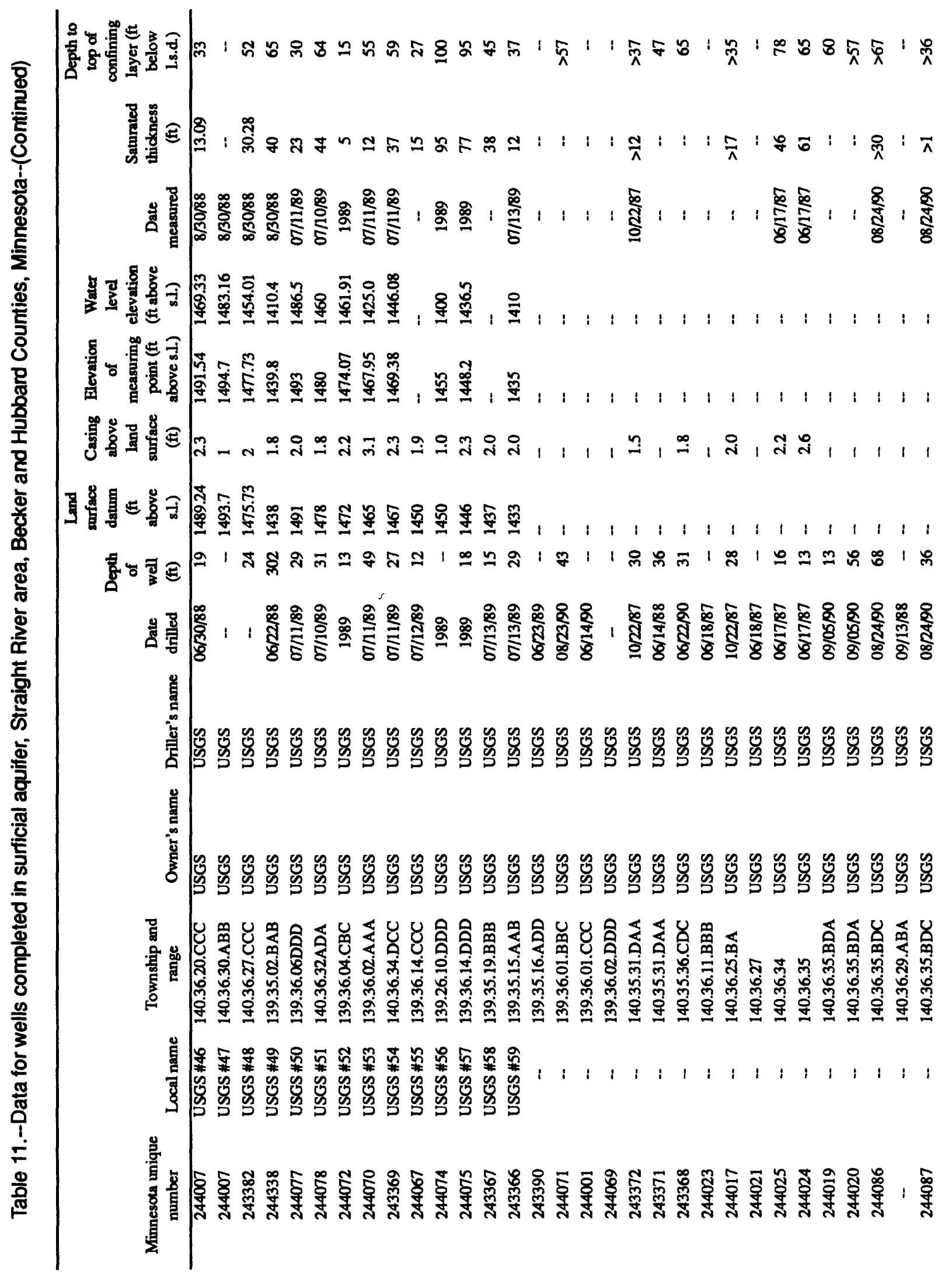




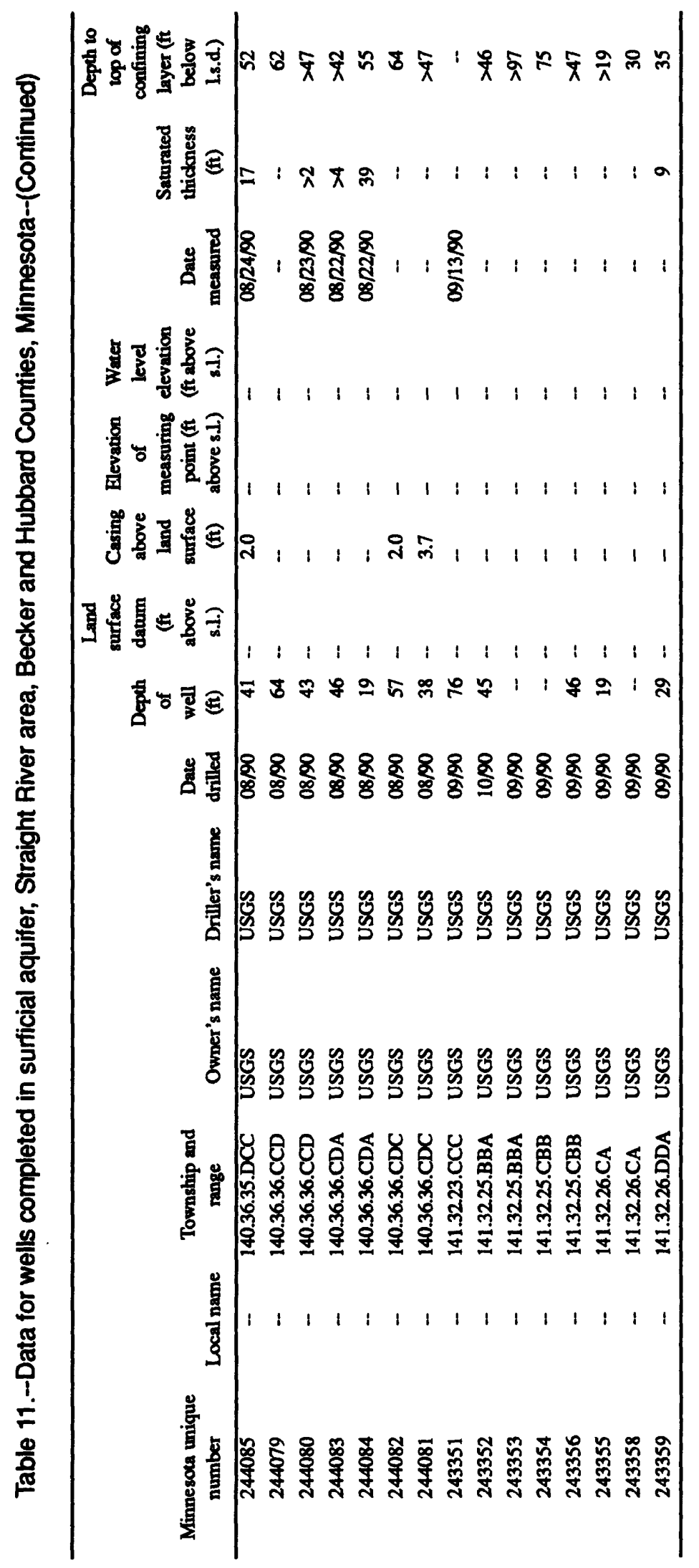




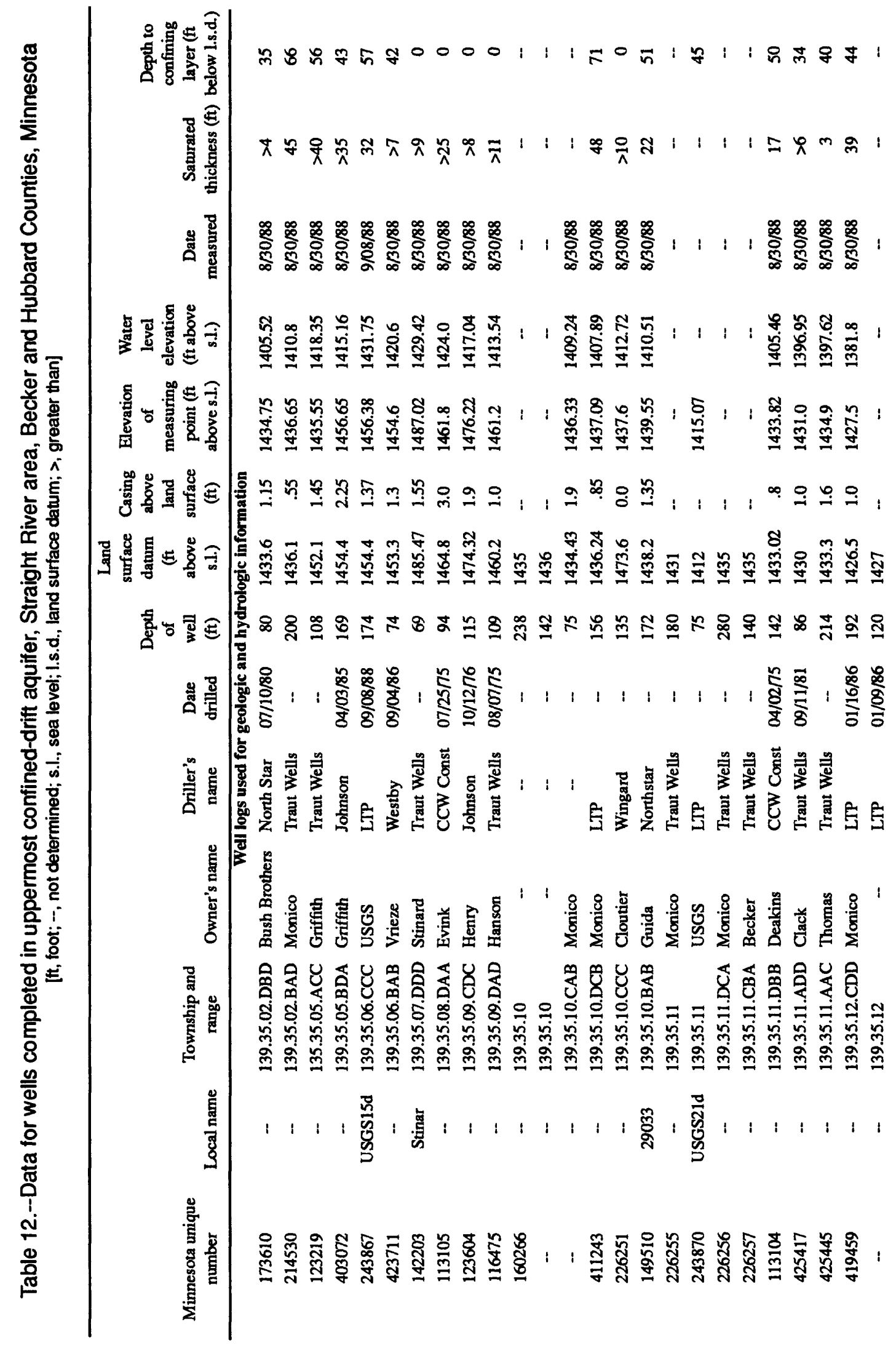




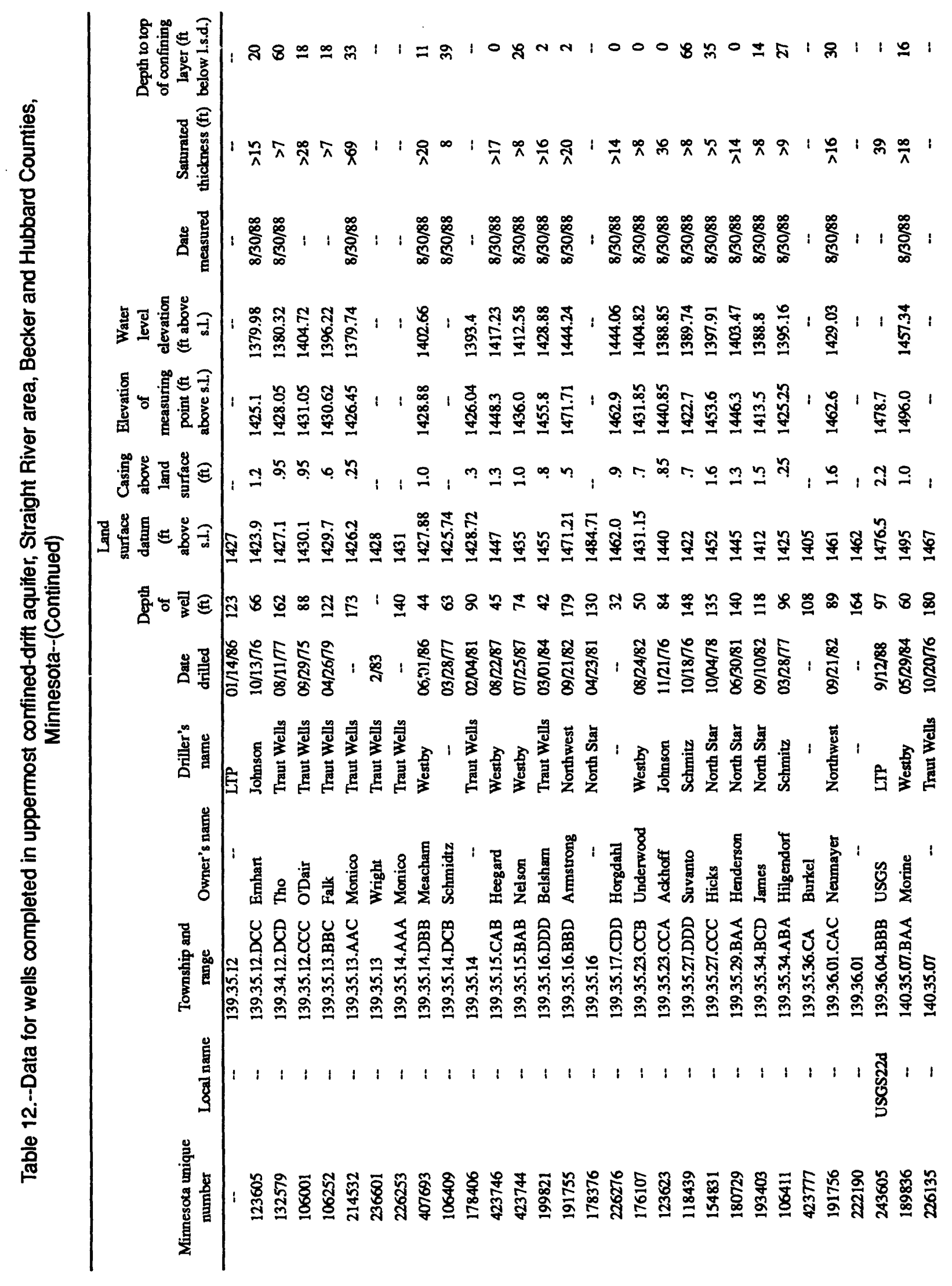




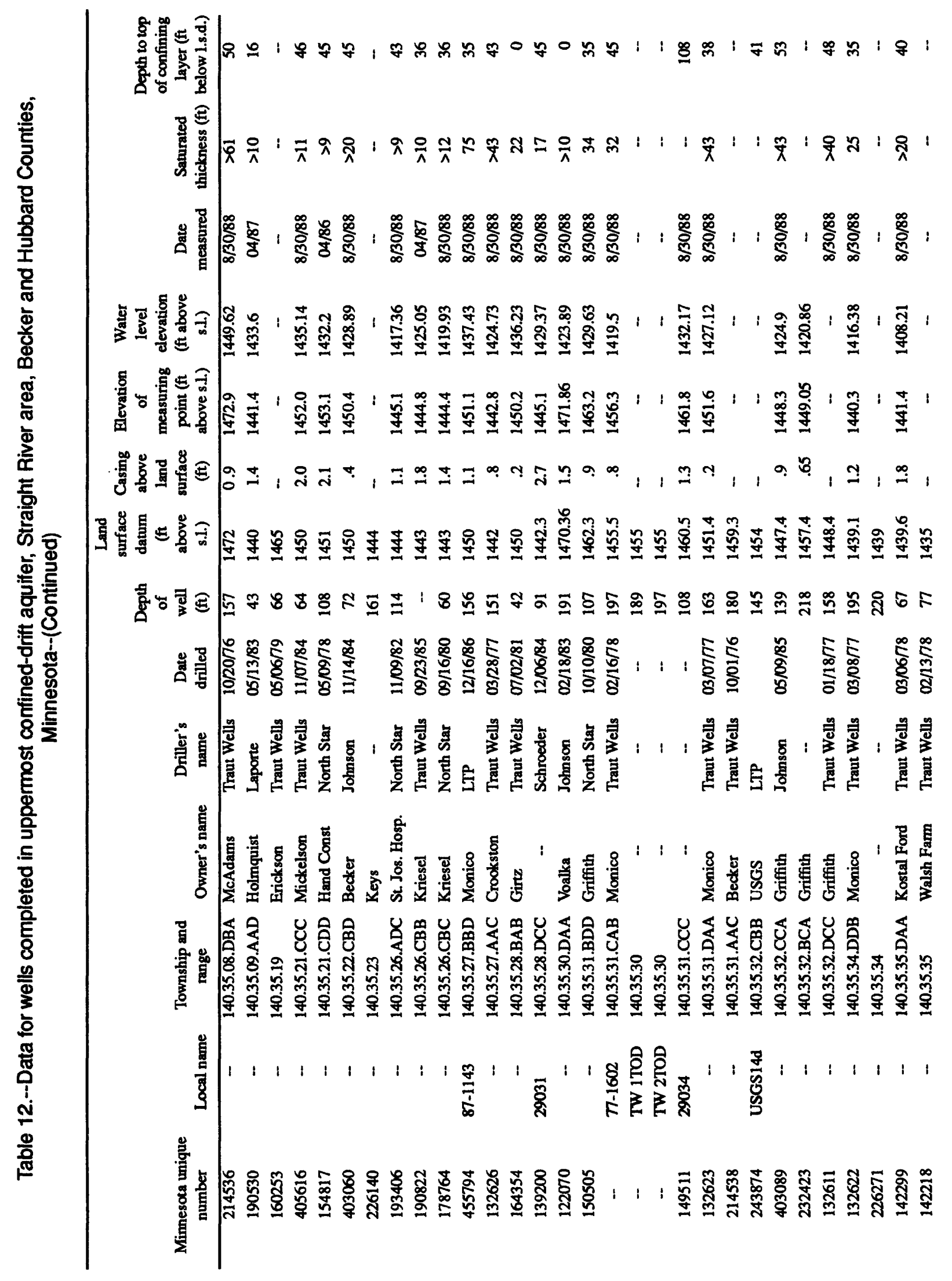




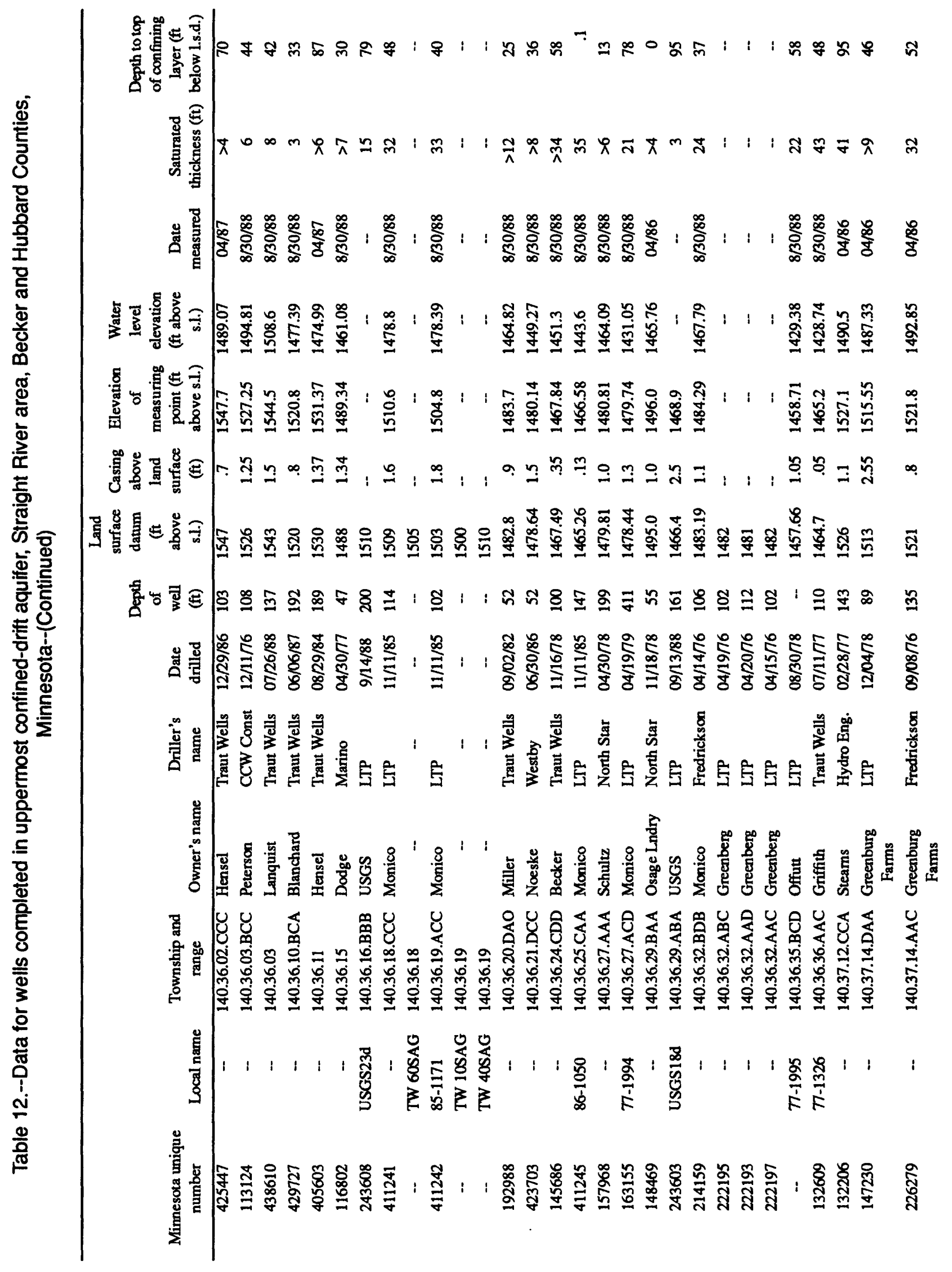




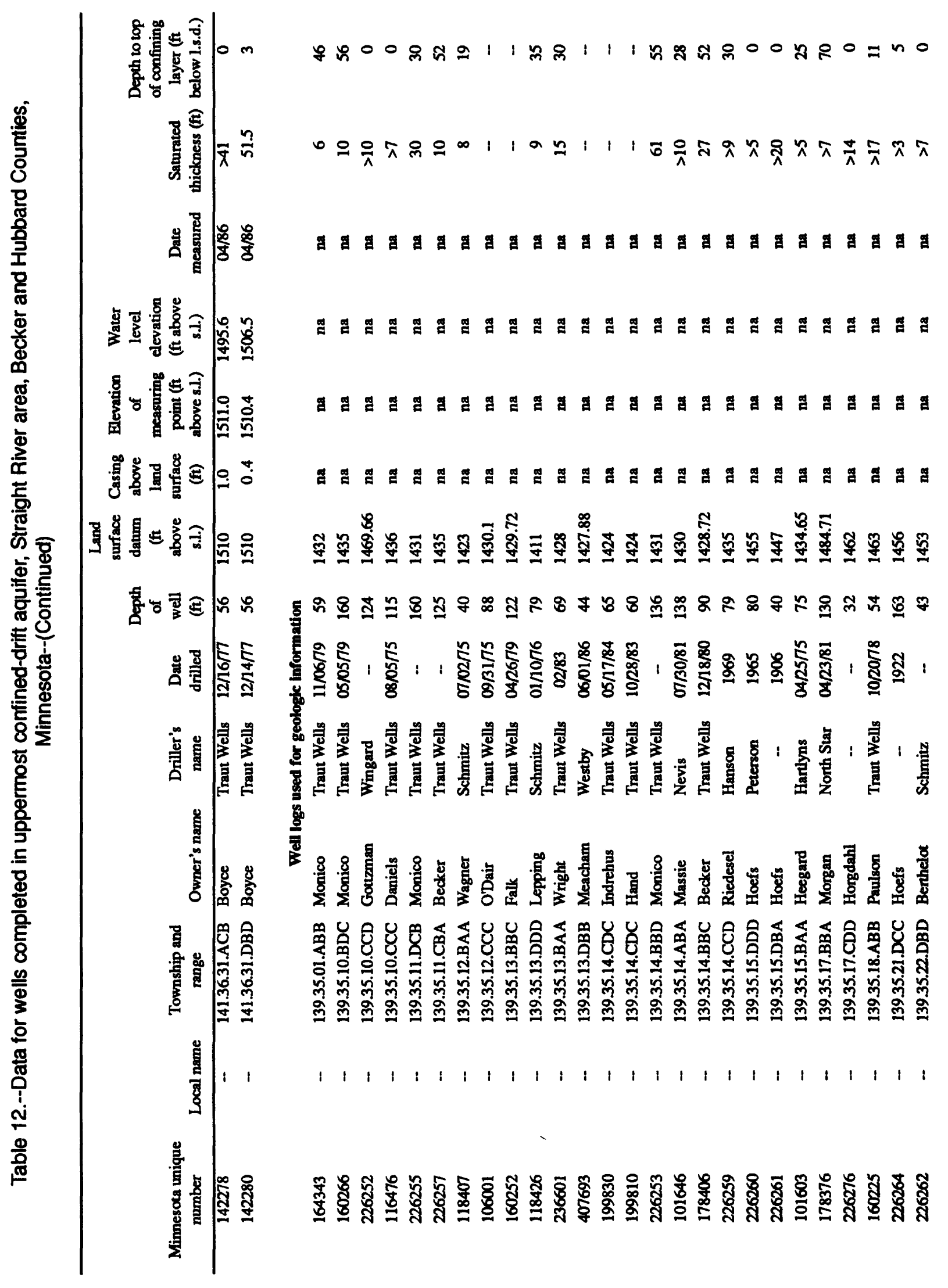




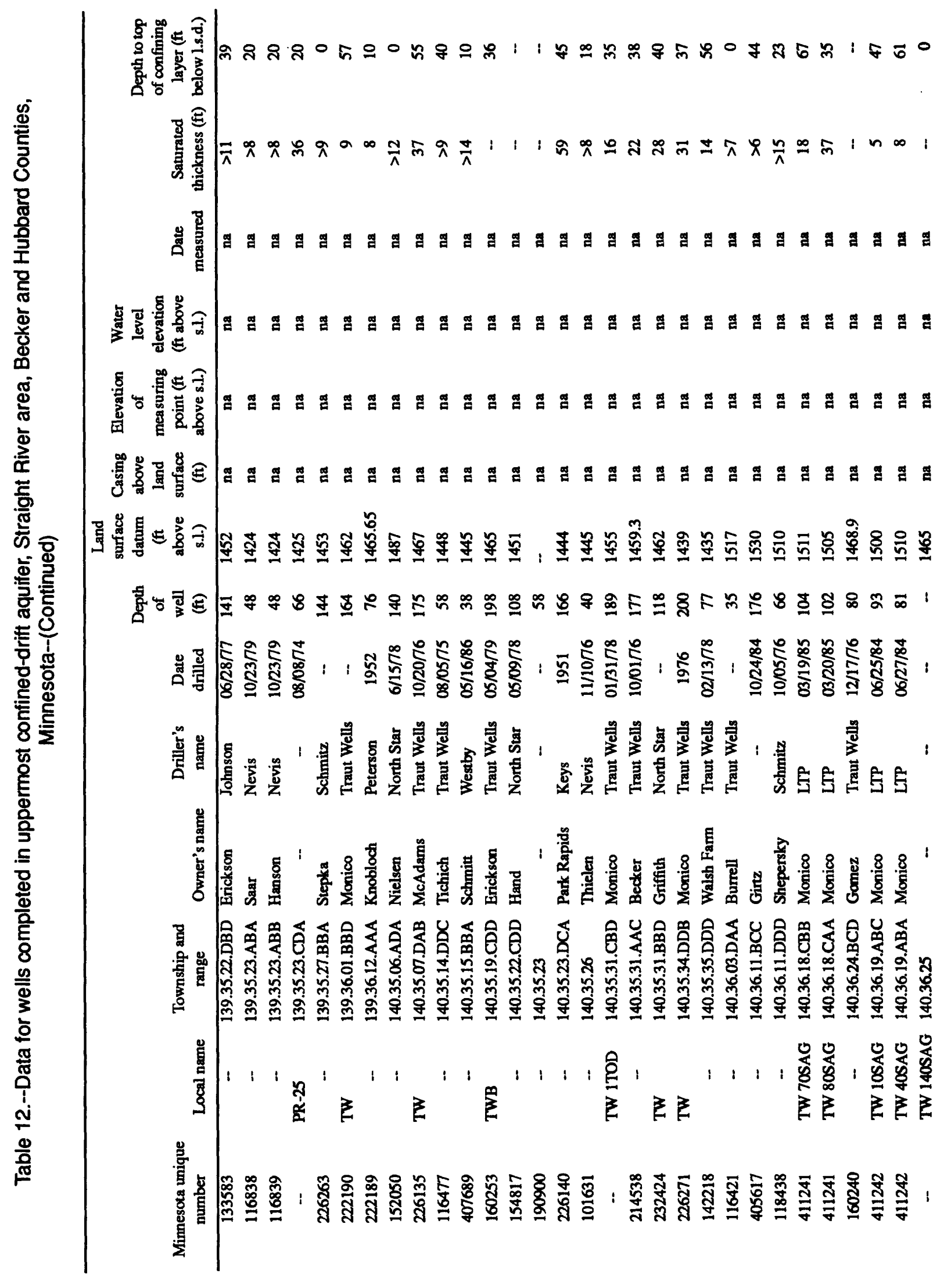




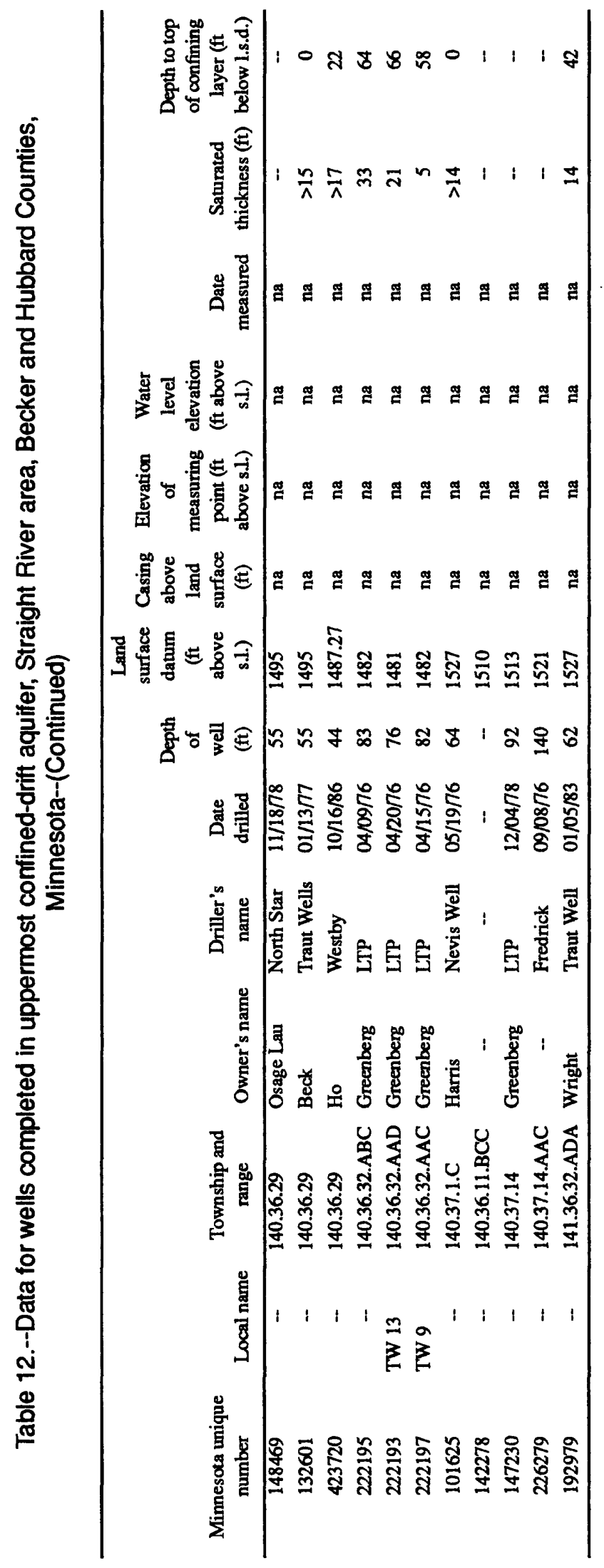

